Prepared in cooperation with the San Gorgonio Pass Water Agency

\title{
Estimating Natural Recharge in San Gorgonio Pass Watersheds, California, 1913-2012
}

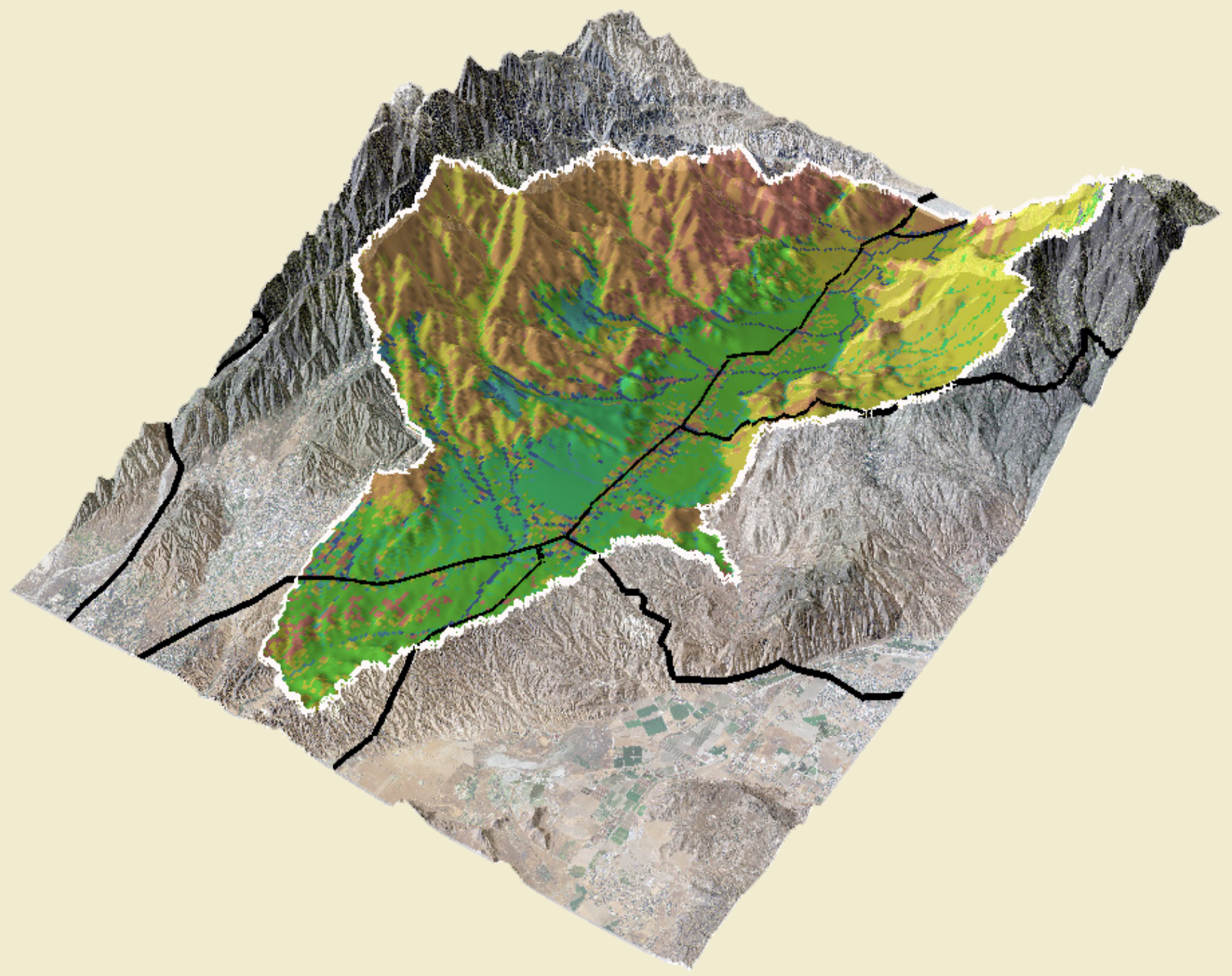

Scientific Investigations Report 2015-5122 
Cover. Simulated average recharge for the San Gorgonio Pass watersheds draped over a three-dimensional image created using U.S. Geological Survey National Elevation Dataset, U.S. Department of Agriculture National Agriculture Imagery Program (2010) and ESRI ArcScene. 


\section{Estimating Natural Recharge in San Gorgonio Pass Watersheds, California, 1913-2012}

By Joseph A. Hevesi and Allen H. Christensen

Prepared in cooperation with the San Gorgonio Pass Water Agency

Scientific Investigations Report 2015-5122 


\section{U.S. Department of the Interior \\ SALLY JEWELL, Secretary}

\section{U.S. Geological Survey \\ Suzette M. Kimball, Acting Director}

U.S. Geological Survey, Reston, Virginia: 2015

For more information on the USGS - the Federal source for science about the Earth, its natural and living resources, natural hazards, and the environment—visit http://www.usgs.gov or call 1-888-ASK-USGS (1-888-275-8747)

For an overview of USGS information products, including maps, imagery, and publications, visit http://www.usgs.gov/pubprod/.

Any use of trade, firm, or product names is for descriptive purposes only and does not imply endorsement by the U.S. Government.

Although this information product, for the most part, is in the public domain, it also may contain copyrighted materials as noted in the text. Permission to reproduce copyrighted items must be secured from the copyright owner.

Suggested citation:

Hevesi, J.A., and Christensen, A.H., 2015, Estimating natural recharge in San Gorgonio Pass watersheds, California, 1913-2012: U.S. Geological Survey Scientific Investigations Report 2015-5122, 74 p. http://dx.doi.org/10.3133/ SIR20155122.

ISSN 2328-0328 (online) 


\section{Acknowledgments}

The authors would like to acknowledge the support of the San Gorgonio Pass Water Agency who cooperatively funded this study.

The authors would like to also acknowledge several individuals that contributed to the technical content of this report, including technical reviewers Claudia C. Faunt (California Water Science Center, CAWSC) and Christopher Kunkel (Oklahoma Water Science Center), surface water specialist reviewer Charles Berenbrock (CAWSC), program chief reviewer Debra S. Curry (CAWSC), editorial reviewer Robin Miller (Sacramento Publishing Science Center, SacPSC), and technical illustrator Donna Knifong (SacPSC). 


\section{Contents}

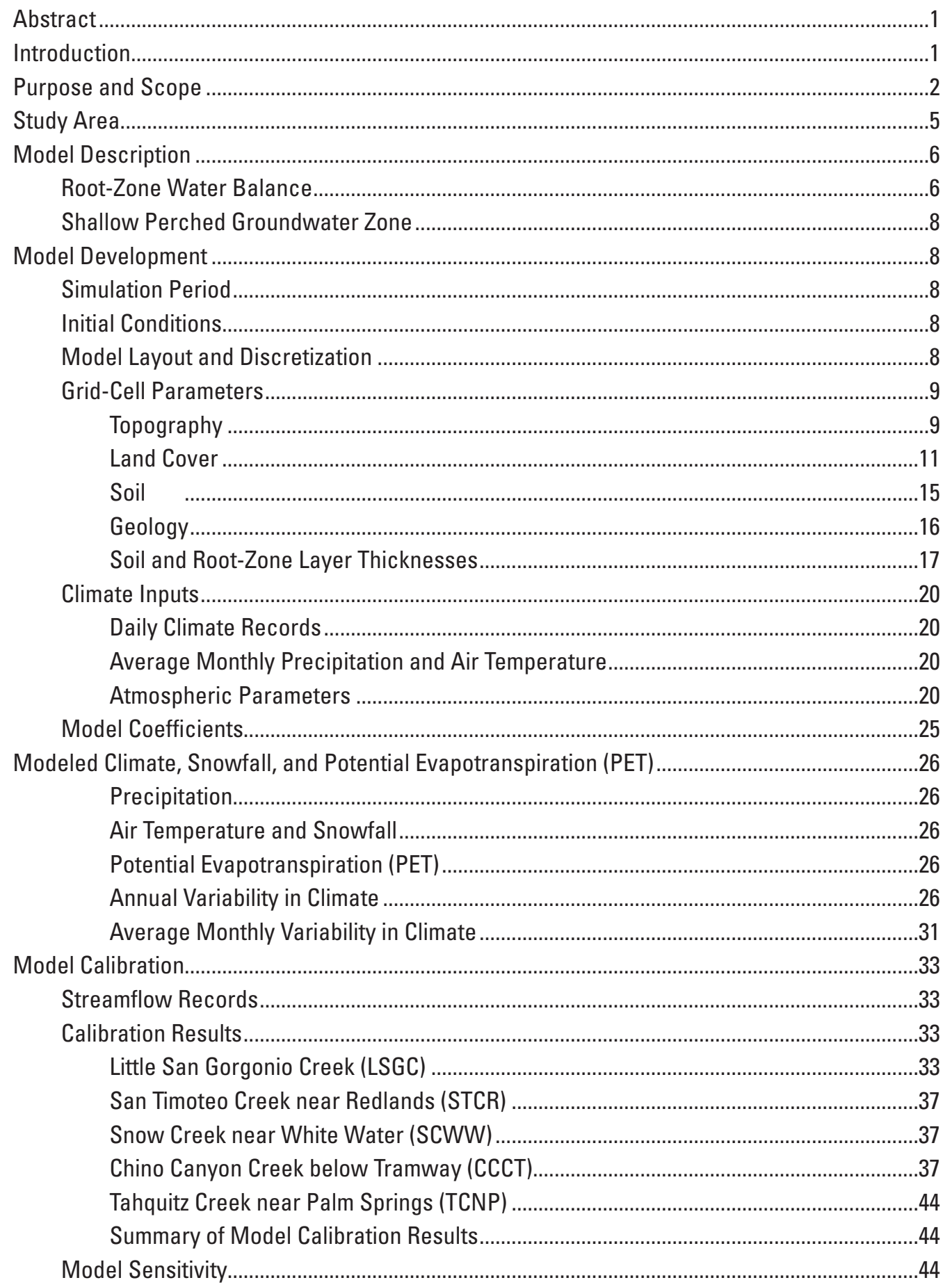




\section{Contents}

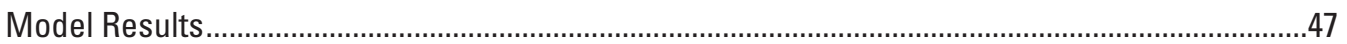

Average Annual Results .........................................................................................................

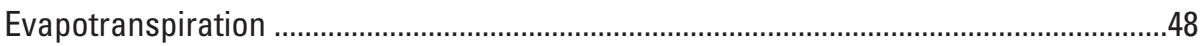

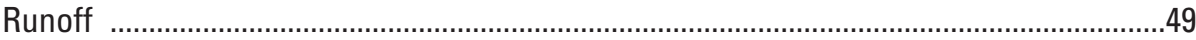

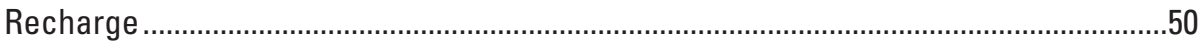

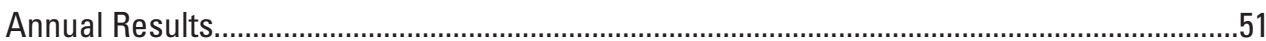

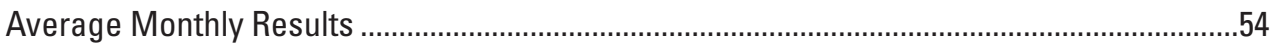

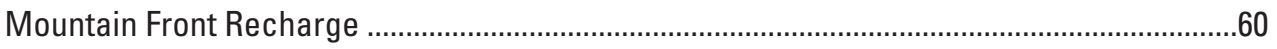

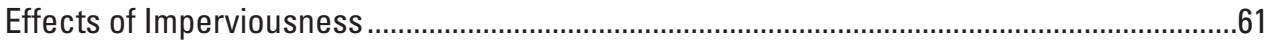

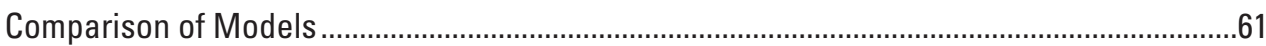

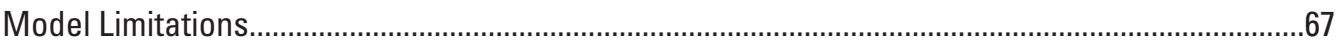

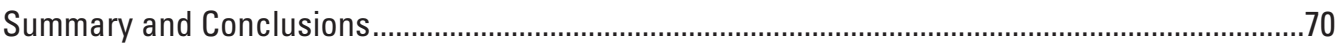

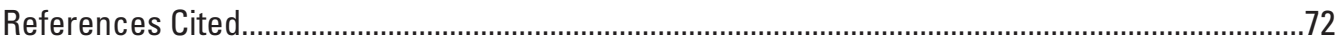

\section{Figures}

1. Map showing study area for the San Gorgonio Pass watershed model, southern California region, California: $A$, hydrographic areas and land-surface altitude; and $B$, groundwater subbasins

2. Diagrams showing representations of the soil zones by the INFILv3 code used for the San Gorgonio Pass watershed model, California, of $A$, the multi-layered root zone; and $B$, the perched zone.

3. Map showing number of upstream cells indicating the cascade flow-routing network for the San Gorgonio Pass watershed model, California

4. Map showing calculated land surface slope used in the San Gorgonio Pass watershed model, California.

5. Map showing percent impervious area, defined as the percentage of the cell area that is covered by an artificial surface such as roadways, rooftops, and parking lots, used in the San Gorgonio Pass watershed model, California.

6. Map showing land-cover type, San Gorgonio Pass watershed model, California...........13

7. Map showing State Soil Geographic Database (STATSGO) soil map units used in the San Gorgonio Pass watershed model, California.

8. Map showing surficial geology used in the San Gorgonio Pass watershed model, California

9. Map showing estimated soil thickness used in the San Gorgonio Pass watershed model, California

10. Map showing estimated layer 6 thickness used in the San Gorgonio Pass watershed model, California.

11. Map showing spatially distributed average annual precipitation estimated for water years 1913-2012 by using the San Gorgonio Pass watershed model, California

12. Map showing spatially distributed average air temperature and snowfall estimated for water years 1913-2012 using the San Gorgonio Pass watershed model, California 


\section{Figures}

13. Map showing spatially distributed average annual potential evapotranspiration simulated for water years 1913-2012 using the San Gorgonio Pass watershed model, California.

14. Graphs showing annual basin-wide averages for water years 1913-2012 using the San Gorgonio Pass watershed model, California, for $A$, estimated precipitation; $B$, estimated air temperature; $C$, simulated snowfall; and $D$, simulated potential evapotranspiration.

15. Graphs showing basin-wide averages for water years 1913-2012, using the San Gorgonio Pass watershed model, California, for $A$, estimated monthly precipitation; $B$, estimated air temperature; $C$, simulated snowfall; and $D$, simulated potential evapotranspiration

16. Map showing location of five streamgages used for model calibration, San Gorgonio Pass watershed model, California..

17. Graphs showing comparison of simulated and measured streamflow at the Little San Gorgonio Creek streamgage using the San Gorgonio Pass watershed model, California: $A$, monthly mean discharge; $B$, water year mean discharge; $C$, average monthly mean discharge; $D$, scatterplot of simulated to measured monthly mean discharge; and $E$, scatterplot of simulated to measured water year mean discharge .

18. Graphs showing comparison of simulated and measured streamflow at the San Timoteo Creek near Redlands streamgage using the San Gorgonio Pass watershed model, California: $A$, monthly mean discharge; $B$, water year mean discharge; $C$, average monthly mean discharge; $D$, scatterplot of simulated against measured monthly mean discharge; and $E$, scatterplot of simulated against measured water year mean discharge...

19. Graphs showing comparison of simulated and measured streamflow at the Snow Creek near White Water streamgage using the San Gorgonio Pass watershed model, California: $A$, monthly mean discharge; $B$, water year mean discharge; $C$, average monthly mean discharge; $D$, scatterplot of simulated to measured monthly mean discharge; and $E$, scatterplot of simulated to measured water year mean discharge

20. Graphs showing comparison of simulated and measured streamflow at the Chino Canyon Creek below Tramway streamgage using the San Gorgonio Pass watershed model, California; $A$, monthly mean discharge; $B$, water year mean discharge; $C$, average monthly mean discharge; $D$, scatterplot of simulated to measured monthly mean discharge; and $E$, scatterplot of simulated to measured water year mean discharge

21. Graphs showing comparison of simulated to measured streamflow at the Tahquitz Creek near Palm Springs streamgage using the San Gorgonio Pass watershed model, California: $A$, monthly mean discharge; $B$, water year mean discharge; $C$, average monthly mean discharge; $D$, scatterplot of simulated versus measured monthly mean discharge; and $E$, scatterplot of simulated versus measured water year mean discharge

22. Map showing average annual evapotranspiration simulated for water years 1913-2012 using the San Gorgonio Pass watershed model, California.

23. Map showing average annual runoff simulated for water years 1913-2012 using the San Gorgonio Pass watershed model, California 


\section{Figures}

24. Map showing average annual recharge simulated for water years 1913-2012 using the San Gorgonio Pass watershed model, California

25. Graph showing simulated annual water budgets for water years 1913-2012 showing inflows, outflows, and changes in storage, using the San Gorgonio Pass watershed model, California.

26. Graphs showing annual simulation results for water years 1913-2012, using the San Gorgonio Pass watershed model: $A$, evapotranspiration; $B$, recharge; and C, runoff.

27. Graphs showing cumulative departure from the mean using the San Gorgonio Pass watershed model, California, for $A$, estimated precipitation and simulated evapotranspiration; and $B$, simulated recharge and runoff .

28. Map showing simulated recharge using the San Gorgonio Pass watershed model, California, for $A$, water year 1993; and $B$, water year 2004.

29. Graphs showing monthly simulation results for selected components of the water budget using the San Gorgonio Pass watershed model, California: $A$, average monthly results for water years 1913-2012; $B$, monthly results for water year 1993; and $C$, monthly results for water year 2004.

30. Map showing san Bernardino and San Jacinto mountain block areas used to simulate mountain-front recharge for the Banning and Cabazon hydrographic areas of the San Gorgonio Pass groundwater study area, San Gorgonio Pass watershed model, California

31. Graphs showing annual simulation results for the San Gorgornio Pass groundwater study area and the San Bernardino and San Jacinto mountain blocks using the San Gorgonio Pass watershed model, California: $A$, recharge; and $B$, runoff.

32. Graphs showing average monthly simulation results for water years 1913 to 2012 for the San Gorgornio Pass groundwater study area and the San Bernardino and San Jacinto mountain blocks using the San Gorgonio Pass watershed model, California: $A$, recharge; and $B$, runoff.

33. Map showing difference in simulated runoff for imperviousness-included minus imperviousness-excluded simulations using the San Gorgonio Pass watershed model, California

34. Map showing difference in simulated recharge for imperviousness-included minus imperviousness-excluded simulations using the San Gorgonio Pass watershed model, California.

35. Map showing difference in simulated recharge results from the updated model minus results from the previous model using the San Gorgonio Pass watershed model, California

36. Graphs showing comparison of annual results for updated and previous models, water years 1930-2001, using the San Gorgonio Pass watershed model, California: $A$, estimated precipitation; $B$, estimated air temperature; $C$, simulated snowfall; $D$, simulated potential evapotranspiration; $E$, simulated evapotranspiration; $F$, simulated recharge; and $G$, simulated runoff.. 


\section{Tables}

1. Vegetation parameters used in the San Gorgonio Pass watershed model, California

2. Soil parameters developed from State Soil Geographic Database (STATSG0) soil map units, root-zone layers 1-5, San Gorgonio Pass watershed model, California

3. Geologic parameters assigned to root-zone layers 6 and 7, San Gorgonio Pass watershed model, California

4. Climate stations having records of daily precipitation or records both of daily precipitation and daily maximum and minimum air temperatures, 1909-2012, used in the San Gorgonio Pass watershed model, California.

5. Parameters for regression models used to spatially interpolate maximum and minimum daily air temperature for the San Gorgonio Pass watershed model, California

6. Monthly values of atmospheric parameters used to simulate solar radiation and potential evapotranspiration with the San Gorgonio Pass watershed model, California

7. Streamflow records used for model testing, San Gorgonio Pass watershed model, California

8. Simulated 100-year water budget using the San Gorgonio Pass watershed model, California: long-term averages for water years 1913-2012

9. Simulated 100-year water budget using the San Gorgonio Pass watershed model, California: results for water year 1993

10. Simulated 100-year water budget using the San Gorgonio Pass watershed model, California: results for water year 2004 


\section{Conversion Factors}

\begin{tabular}{|c|c|c|}
\hline Multiply & By & To obtain \\
\hline \multicolumn{3}{|c|}{ Length } \\
\hline millimeter (mm) & 0.03937 & inch (in.) \\
\hline meter $(\mathrm{m})$ & 3.281 & foot $(\mathrm{ft})$ \\
\hline meter $(\mathrm{m})$ & 1.094 & yard (yd) \\
\hline \multicolumn{3}{|c|}{ Area } \\
\hline hectare (ha) & 2.471 & acre \\
\hline square kilometer $\left(\mathrm{km}^{2}\right)$ & 0.3861 & square mile $\left(\mathrm{mi}^{2}\right)$ \\
\hline \multicolumn{3}{|c|}{ Volume } \\
\hline cubic meter $\left(\mathrm{m}^{3}\right)$ & 264.2 & gallon (gal) \\
\hline cubic meter $\left(\mathrm{m}^{3}\right)$ & 35.31 & cubic foot $\left(\mathrm{ft}^{3}\right)$ \\
\hline cubic meter $\left(\mathrm{m}^{3}\right)$ & 0.0008107 & acre-foot (acre-ft) \\
\hline \multicolumn{3}{|c|}{ Flow rate } \\
\hline cubic meter per second $\left(\mathrm{m}^{3} / \mathrm{s}\right)$ & 70.07 & acre-foot per day (acre-ft/d) \\
\hline meter per year $(\mathrm{m} / \mathrm{yr})$ & 3.281 & foot per year (ft/yr) \\
\hline cubic meter per day $\left(\mathrm{m}^{3} / \mathrm{d}\right)$ & 35.31 & cubic foot per day $\left(\mathrm{ft}^{3} / \mathrm{d}\right)$ \\
\hline cubic meter per day $\left(\mathrm{m}^{3} / \mathrm{d}\right)$ & 264.2 & gallon per day (gal/d) \\
\hline milligrams per day $(\mathrm{mm} / \mathrm{d})$ & 0.0016 & inch per hour (in/h) \\
\hline millimeter per year (mm/yr) & 0.03937 & inch per year (in/yr) \\
\hline
\end{tabular}

\section{Supplemental Information}

Temperature in degrees Celsius $\left({ }^{\circ} \mathrm{C}\right)$ may be converted to degrees Fahrenheit $\left({ }^{\circ} \mathrm{F}\right)$ as ${ }^{\circ} \mathrm{F}=\left(1.8 \times{ }^{\circ} \mathrm{C}\right)+32$.

\section{Datum}

Horizontal coordinate information is referenced to the North American Datum of 1983 (NAD 83). Altitude, as used in this report, refers to distance above the vertical datum. 


\section{Abbreviations}

\begin{tabular}{ll} 
CCCT & Chino Canyon Creek below Tramway \\
CIMIS & California Irrigation Management Information System \\
CIWMC & California Interagency Watershed Mapping Committee \\
D-8 & eight direction \\
DWR & California Department of Water Resources \\
ET & Evapotranspiration \\
ETo & Reference Evapotranspiration \\
GIS & Geographic Information System \\
GSFLOW & Groundwater and Surface water Flow model \\
HA & hydrographic area \\
HSA & hydrographic subarea \\
INFILV3 & INFILtration code version 3.0 \\
LCMMP & California Land Cover Mapping and Monitoring Program \\
LOWESS & Locally Weighted Scatterplot Smoothing \\
LSGC & Little San Gorgonio Creek \\
NED & National Elevation Dataset \\
NLCD & National Land Cover Data \\
NSME & Nash-Sutcliffe Model Efficiency \\
PAEE & percent average estimation error \\
PET & potential evapotranspiration \\
PRISM & Parameter Regression on Independent Slopes Model \\
PTC & Potrero Creek \\
SCWW & Snow Creek near White Water \\
SGPGSA & San Gorgonio Pass groundwater study area \\
SGPWA & San Gorgonio Pass Water Agency \\
SGPWM & San Gorgonio Pass watershed model \\
SGR & San Gorgonio River \\
STATSG0 & State Soil Geographic Database \\
STC & San Timoteo Creek \\
STCR & San Timoteo Creek near Redlands \\
USGS & U.S. Geological Survey \\
\hline ST
\end{tabular}




\title{
Estimating Natural Recharge in San Gorgonio Pass Watersheds, California, 1913-2012
}

\author{
By Joseph A. Hevesi and Allen H. Christensen
}

\section{Abstract}

A daily precipitation-runoff model was developed to estimate spatially and temporally distributed recharge for groundwater basins in the San Gorgonio Pass area, southern California. The recharge estimates are needed to define transient boundary conditions for a groundwater-flow model being developed to evaluate the effects of pumping and climate on the long-term availability of groundwater. The area defined for estimating recharge is referred to as the San Gorgonio Pass watershed model (SGPWM) and includes three watersheds: San Timoteo Creek, Potrero Creek, and San Gorgonio River. The SGPWM was developed by using the U.S. Geological Survey INFILtration version 3.0 (INFILv3) model code used in previous studies of recharge in the southern California region, including the San Gorgonio Pass area. The SGPWM uses a 150-meter gridded discretization of the area of interest in order to account for spatial variability in climate and watershed characteristics. The high degree of spatial variability in climate and watershed characteristics in the San Gorgonio Pass area is caused, in part, by the high relief and rugged topography of the area.

Daily climate data developed from a network of monitoring sites and published average monthly precipitation maps were used to develop the climate inputs for the SGPWM. Geographic Information System (GIS) data defining land surface altitude, vegetation, soils, surficial geology, and land cover were used to define input parameters representing the physical characteristics of the land surface, root zone, and shallow subsurface underlying the root zone. Model parameterization was based on a previous INFILv3 model developed for an area including the upper parts of the San Timoteo Creek and Potrero Creek drainages and the western part of the San Gorgonio River watershed. The previous INFILv3 model was calibrated by using available streamflow records from the model area. The SGPWM uses an updated INFILv3 version to represent shallow groundwater flow better beneath the root zone that contributes to lateral, downslope seepage rather than deep recharge. The SGPWM calibration was tested by using available streamflow records in the San Gorgonio Pass region.
The SGPWM was used to simulate a 100 -year water budget, including recharge and runoff, for water years 1913 through 2012. Results indicated that most recharge came from episodic infiltration of surface-water runoff in the larger stream channels. Results also indicated periods of great variability in recharge and runoff in response to variability in precipitation. More recharge was simulated for the area of the groundwater basin underlying the more permeable alluvial fill of the valley floor compared to recharge in the neighboring upland areas of the less permeable mountain blocks. The greater recharge was in response to the episodic streamflow that discharged from the mountain block areas and quickly infiltrated the permeable alluvial fill of the groundwater basin. Although precipitation at the higher altitudes of the mountain block was more than double precipitation at the lower altitudes of the valley floor, recharge for inter-channel areas of the mountain block was limited by the lower permeability bedrock underlying the thin soil cover, and most of the recharge in the mountain block was limited to the main stream channels underlain by alluvial fill.

\section{Introduction}

The San Gorgonio Pass Water Agency (SGPWA) is a regional water agency, established in 1961, that helps protect local groundwater basins in the San Gorgonio Pass region of southern California (http://www.sgpwa.com). The SGPWA is concerned with meeting water demands from Calimesa to Cabazon, California. The SGPWA service area is about 554 square kilometers $\left(\mathrm{km}^{2}\right)$ of semi-arid badlands, alluvial plains, benches, and canyon watersheds that are in the San Gorgonio Pass region of southern California, about 137 kilometers $(\mathrm{km})$ east of Los Angeles (fig. 1A). The SGPWA (fig. $1 B$ ) includes areas in the San Gorgonio Pass and the San Timoteo groundwater subbasins (California Department of Water Resources, 2003). The SGPWA also includes areas in the Noble Creek, Cherry Valley, Beaumont, Banning, Cabazon, and Gilman Hot Springs Hydrographic Subareas (HSAs) defined by the California Interagency 
Watershed Mapping Committee (CIWMC; 2004). This study, by the U.S. Geological Survey (USGS) in cooperation with the SGPWA, is a component of studies to evaluate the groundwater resources in the areas of the San Timoteo and San Gorgonio Pass groundwater subbasins, including a small part of the westernmost edge of the Indio groundwater subbasin (fig. $1 B$ ). This area includes the groundwater storage units identified by Bloyd (1971). The area of interest for these groundwater studies is referred to as the San Gorgonio Pass groundwater study area (SGPGSA) in this report. The SGPGSA is bounded by the San Bernardino Mountains to the north, the Whitewater River drainage to the east, the San Jacinto Mountains to the south, the San Timoteo Badlands and the Potrero Creek drainage to the southwest, and the San Timoteo Creek drainage to the west (fig. $1 A$ ). The primary directions of surface-water and groundwater outflow from the SGPGSA are eastward toward the downstream parts of the San Gorgonio and Whitewater River drainages on the east and westward towards the San Timoteo drainage on the west. A minor amount of outflow also goes southward toward the downstream part of the Potrero Creek drainage along the southwestern boundary. The drainage divide between the San Timoteo Creek drainage and the San Gorgonio River drainage is defined by the boundary between the Noble Creek and Cabazon HSAs. The drainage divide between the San Timoteo Creek drainage and the Potrero Creek drainage is defined by the boundary between the Beaumont and Gilman Hot Springs HSAs. The drainage divide between the San Gorgonio River drainage and the Potrero Creek drainage is defined by the boundary between the Banning and Gilman Hot Springs HSAs.

Groundwater has been the only source of potable water supply for residential, industrial, and agricultural users in the Beaumont and Banning areas of the San Gorgonio Pass region (Rewis and others, 2006). The SGPWA has developed an extensive groundwater database to help manage and protect the local groundwater-storage units identified by Bloyd (1971). Groundwater levels near Beaumont declined by as much as 100 feet (ft) between the early 1920s and early 2000s, and numerous natural springs have stopped flowing in the San Timoteo subbasin (Bloyd, 1971). Because of the ongoing concerns regarding future availability of groundwater resources, the SGPWA is evaluating groundwater storage in the San Gorgonio Pass area, including the San Gorgonio Pass and San Timoteo subbasins.

Much of the area served by the SGPWA is experiencing groundwater overdraft, where more water is pumped out of the ground each year than is replaced by nature through rain and snowmelt (http://www.sgpwa.com/faq/). Since 2003, the SGPWA has been importing water through the California Aqueduct to recharge local groundwater basins used by retail water companies, by private companies, and by individuals for domestic and other purposes. According to the SGPWA, without the imported water and with continued groundwater usage at rates similar to past rates, groundwater levels would likely continue to decline (in some areas, water levels have decreased nearly 90 feet in the past 70 years). A continued decline in groundwater levels would likely cause some wells to dry up, and the power required to pump the water to the surface would also likely continue to increase each year. The overall objective of the groundwater studies is to evaluate the groundwater resources of the SGPGSA and, additionally, to determine the hydrologic response of the groundwater system to future climatic conditions and projected land use. The future climatic conditions could change the amount of available recharge, while the projected land uses could require more water.

The availability of groundwater in the SGPWA service area has been evaluated by using groundwater-flow models (Bloyd, 1971; Rewis and others, 2006). An important component of groundwater models is the inflow to the groundwater system from natural recharge (Reichard and others, 2003; Nishikawa and others, 2004; Rewis and others, 2006; Belcher and Sweetkind, 2010. Natural recharge includes recharge in direct response to precipitation, snowmelt, and infiltration of surface runoff and streamflow.

Estimates of natural recharge have been made in the southern California region by using precipitation-runoff models, including in the Death Valley region (Hevesi and others, 2003), the Joshua Tree area (Nishikawa and others, 2004), Big Bear Valley (Flint and Martin, 2012), and the western part of the SGPGSA (Rewis and others, 2006). The precipitation-runoff models in these studies were developed by using the INFIL version 3.0 (INFILv3) model code (U.S. Geological Survey, 2008), and recharge was simulated as a component of the water budget. Results for the previous INFILv3 model developed for the western SGPGSA (Rewis and others, 2006), referred to here as the Rewis model, consisted of the spatially and temporally distributed recharge and runoff for water years 1930-2001, and included natural recharge simulated in the area of a groundwater model developed for the western SGPSA as well as natural recharge simulated for drainages in the mountain block areas upstream of and bordering the boundary of the groundwater model. A portion of the total recharge simulated by the INFILv3 model for the upstream drainages was included as a mountainfront recharge boundary condition for the groundwater model (Rewis and others, 2006).

\section{Purpose and Scope}

The purpose of this report is to document a study done to provide updated estimates of transient areal and mountainfront recharge for the SGPGSA by using a deterministic precipitation-runoff modeling approach. The study presented in this report is an enhancement of the Rewis model developed by Rewis and others (2006). The model enhancement was done (1) to cover the total area of the SGPGSA, including the eastern extent of the Cabazon Hydrographic Area (HA); (2) to include more recent climate records to enable a longer 


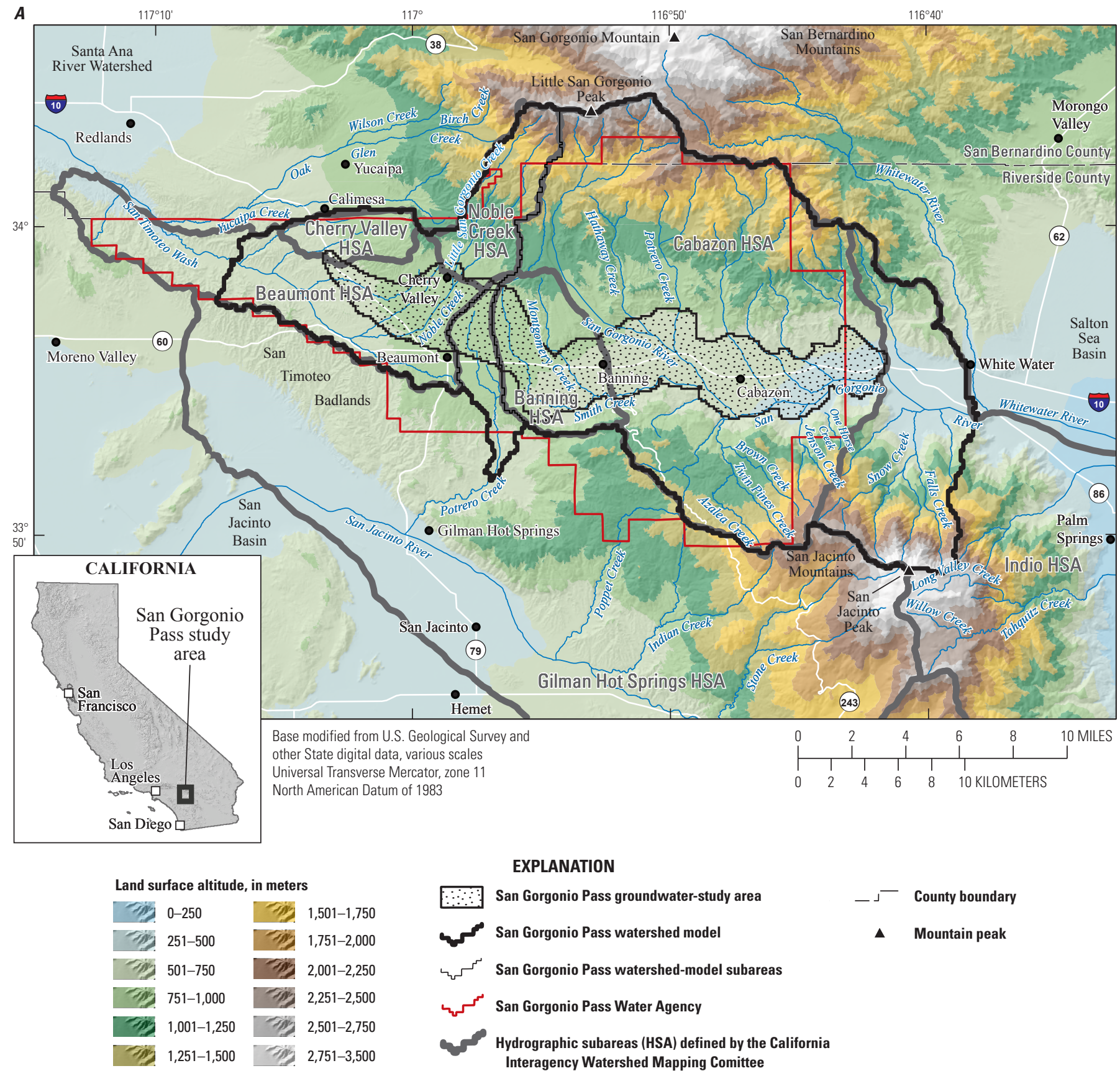

Figure 1. Study area for the San Gorgonio Pass watershed model, southern California region, California: $A$, hydrographic areas and land-surface altitude; and $B$, groundwater subbasins. 


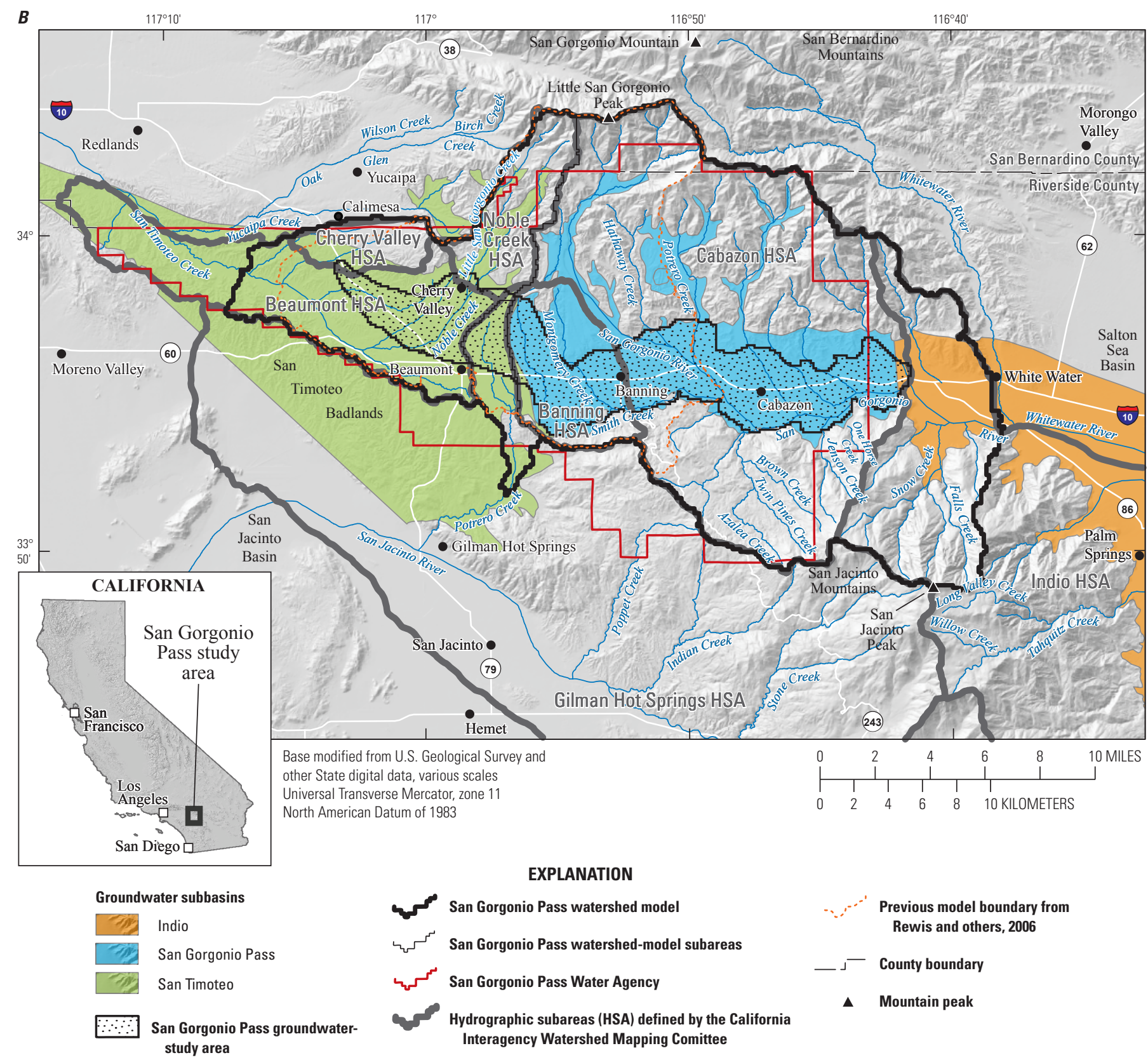

Figure 1. - Continued

simulation period; (3) to include the INFILv3 seepage-flow modification developed in Flint and Martin (2012); and (4) to use a model grid matched to the grid being considered for groundwater modeling studies. The model was developed primarily as an expansion and update of the Rewis model (Rewis and others, 2006). A limited calibration was performed on the model for selected parameters by comparing simulated and measured streamflow at streamgage locations.

In contrast to transient recharge estimated by using empirical precipitation-scaling methods (Reichard and others, 2003; Farrar and others, 2006), the precipitationrunoff modeling approach provides a more physically based method for estimating the spatial and temporal distribution of recharge. The advantage of the precipitation-runoff method is that it provides a process-based representation of variations in recharge caused by the spatially varying physical characteristics of the watersheds being modeled. The precipitation-runoff modeling method also provides a process-based representation of variations in all components of the water budget, including recharge and runoff, caused by the effects of temporal and spatial differences in temperature and precipitation. In general, deterministic precipitation-runoff models are more applicable to evaluating hydrologic responses to variations in climate and watershed characteristics compared to empirical methods and provide a more appropriate tool for evaluating the effects of potential management scenarios. Model results can be mapped and subsequently used to evaluate the integrated effect of spatially distributed climate, terrain, and watershed 
characteristics (for example, land cover, soils, and geology) on the spatial and temporal distribution of runoff and potential recharge.

The INFILv3 application presented in this report included an expanded model domain that contains all surface-water drainages potentially contributing runoff and recharge inflows to the SGPGSA. The model used a simulation period of 100 years, starting with water year 1913 and ending with water year 2012. The 100-year simulation period was used to evaluate temporal and spatial variability in natural recharge as well as long-term average recharge rates. To provide a more efficient coupling between the INFILv3 model and a groundwater-flow model being developed for the SGPGSA, the model grid size was increased from 30 to 150 meters (m), and the grid orientation was matched to the grid size and orientation used for the groundwater-modeling studies of the SGPGSA. This updated model was used to develop monthly and daily recharge results in the SGPGSA as well as for the surrounding drainages that had the potential to contribute inflows to the SGPGSA. To represent shallow subsurfaceflow paths beneath the root zone that can result in a seepage inflows to downslope areas, the updated model used a version of INFILv3 that included a seepage-flow component (Flint and Martin, 2012). The seepage-flow component allows for the lateral redistribution of potential recharge (where potential recharge is infiltration through the root zone). To more directly represent the effect of impervious areas on simulated recharge and runoff, the INFILv3 code was modified to allow for the partitioning of grid cells into pervious and impervious components.

The precipitation-runoff model does not account for induced recharge from retention basins, spreading grounds, and injection wells. To help evaluate potential effects of urbanization on the hydrologic system, however, the model was applied to evaluate changes in runoff and recharge in response to impervious areas associated with urban-land uses. Model results were also compared to results obtained by using the Rewis model (Rewis and others, 2006).

\section{Study Area}

The study area for this report is defined as the San Gorgonio Pass watershed model (SGPWM), and covers $688 \mathrm{~km}^{2}$ (fig. 1). The SGPWM is in the western parts of San Bernardino and Riverside counties. The SGPWM consists of three separate model domains that were simulated separately: (1) The San Timoteo Creek drainage, (2) the Potrero Creek drainage, and (3) the San Gorgonio River drainage. The SGPWM area was defined on the basis of the need to include all surface-water drainages that could potentially affect the natural recharge boundary condition for the SGPGSA, including spatially distributed recharge in the SGPGSA and mountain-front recharge from the drainages bordering the SGPGSA.
The SGPWM is bounded by Little San Gorgonio Peak and the San Bernardino Mountains to the north and San Jacinto Peak and the San Jacinto Mountains to the south (fig. 1A). The northern part of the SGPWM includes the rugged terrain of the San Bernardino Mountains. Land-surface altitudes range from a low of $200 \mathrm{~m}$ in the valley of the Indio subbasin along the eastern boundary of the SGPWM to a high of 2,900 m at the summit of Little San Gorgonio Peak. The southern part of the SGPWM includes the very steep and rugged terrain of the San Jacinto Mountains, which reach an altitude of 3,300 m at the summit of San Jacinto Peak, the highest location in the SGPWM. The upland terrain of the mountain block areas to the north and south of the SGPGSA has land cover consisting primarily of natural vegetation. The soil cover is generally thin in the upland areas, and the underlying bedrock consists primarily of low-permeability crystalline rocks. The lower altitudes of the valley floor are underlain by thicker soils and alluvial deposits. Urban development is limited primarily to the lower altitudes of the valley floor.

The SGPWM includes three main surface-water drainages: San Timoteo Creek draining to the west, San Gorgonio River draining toward the east, and Potrero Creek draining toward the south (fig. 1A). The San Timoteo Creek and Potrero Creek drainages are tributaries of the Santa Ana River watershed, which drains westward into the Pacific Ocean, and the San Gorgonio River drainage is a tributary of the Whitewater River watershed, which drains southeastward into the Salton Sea basin. The three surface-water drainages were modeled separately by using the three SGPWM model domains.

Streamflow in the SGPWM is generally ephemeral to intermittent; however, low flows are maintained by spring discharge for some of the smaller tributaries in the mountain blocks. Prolonged streamflow of several weeks and longer can also be maintained in some channels by snowmelt. The San Timoteo Creek drainage includes three HSAs defined by the California Interagency Watershed Mapping Committee (2004): Noble Creek, Cherry Valley, and Beaumont (fig. 1). The Noble Creek and Cherry Valley HSAs are tributaries to the Beaumont HSA, which includes areas downstream and outside of the San Timoteo Creek drainages. The San Gorgonio River drainage also includes three HSAs defined by the CIWMC: Banning, Cabazon, and Indio. The Banning HSA is upstream of the Cabazon HSA, the Cabazon HSA is upstream of the Indio HSA, and the Indio HSA includes areas downstream of the San Gorgonio River drainage.

Climate is a critical characteristic of the hydrologic system represented by the SGPWM. Variations in the timing, frequency, amount, and spatial distributions of precipitation are important factors affecting the hydrologic system. Spatial and temporal variations in air temperature, including diurnal differences between maximum and minimum daily temperature, are critical factors affecting the energy available for evapotranspiration (ET) and the form of precipitation (rain or snow). In the southern California region, precipitation falls primarily during the cooler months of October through May. 
The months of June through September are generally hot and dry for most locations. Notable spatial variability in climate is based on distance from the coastline and topography; these both affect precipitation and air temperature. Inland locations are generally hotter during the summer and colder during the winter compared to locations closer to the coastline. Higher elevations are generally colder and wetter compared to the low-lying coastal plane and interior valleys. Temperature inversions, where colder, denser air sinks to the valley floor, are common in the interior basins of southern California.

The San Gorgonio Pass area is in a transition zone of higher precipitation and lower potential evapotranspiration (PET) toward the west and lower precipitation and higher PET to the east. Potential evapotranspiration, also referred to as reference evapotranspiration $\left(\mathrm{ET}_{\mathrm{o}}\right.$ ), is estimated throughout California by the California Irrigation Management and Information System (CIMIS) using a network of field monitoring stations (California Irrigation Management and Information System, (CIMIS), 2005). The ET estimate represents the maximum amount or rate of evapotranspiration under fully saturated conditions (California Irrigation Management and Information System, (CIMIS), 2005). According to CIMIS, $\mathrm{ET}_{\mathrm{o}}$ for the general area of the SGPWM is about 1,600 millimeters per year $(\mathrm{mm} / \mathrm{yr})$. The SGPWM is mostly in the CIMIS ET zone number 16, with a minimum average monthly PET of about 40 millimeters $(\mathrm{mm})$ for December and January and a maximum average monthly PET of about $240 \mathrm{~mm}$ for July (California Irrigation Management and Information System,(CIMIS), 2005). The easternmost part of the SGPWM is in CIMIS ET zone $^{18}$, with a higher annual $\mathrm{ET}_{\mathrm{o}}$ of about $1,800 \mathrm{~mm} / \mathrm{yr}$. The westernmost part of the SGPWM is within CIMIS ET zone 9, with a lower annual PET of about $1,400 \mathrm{~mm} / \mathrm{yr}$.

\section{Model Description}

The SGPWM was developed by using the INFILv3 code (U.S. Geological Survey, 2008). INFILv3 is a deterministic, grid-based, distributed-parameter, precipitation-runoff modeling application that calculates the temporal and spatial distribution of daily net infiltration at the lower boundary of the root zone. The bottom of the root zone is the estimated maximum depth below ground surface affected by ET. In many field applications, net infiltration can be assumed to equal recharge to an underlying water-table aquifer and can be used to define the recharge boundary condition for groundwater-flow models (Hevesi and others, 2003; Nishikawa and others, 2004; Rewis and others, 2006). A more detailed description of INFILv3 modeling code is provided in Hevesi and others (2003) and USGS (2008). The INFILv3 code and documentation are available at http://water.usgs.gov/ nrp/gwsoftware/Infil/Infil.html.
The INFILv3 code requires the discretization of the watershed being simulated into a horizontal grid-based network of model cells (fig. 2). The grid-based discretization is used to spatially distribute daily climate inputs and model parameters representing the physical characteristics of the watersheds in the model domain. The model cells are connected into a drainage network, and runoff generated by a cell is routed across the grid by using a simple cascading flowrouting process (U.S. Geological Survey, 2008).

The INFILv3 code provides an estimate of recharge based on simulated daily net infiltration, where net infiltration is defined as the percolation of water below the maximum depth of the root zone (or the zone of ET) in response to infiltration from rain, snowmelt, and surface-water inflows (Hevesi and others, 2003; Nishikawa and others, 2004; Rewis and others, 2006; U.S. Geological Survey, 2008; Flint and Martin, 2012). Daily net infiltration and evapotranspiration are simulated by INFILv3 using a multi-layered representation of the root zone, and simulated daily runoff is allowed to infiltrate back into the root zone during the process of surface-water flow routing, thereby accounting for the effects of streamflow on recharge (fig. $2 A$ ).

\section{Root-Zone Water Balance}

INFILv3 uses six layers to simulate the root-zone water balance, including net infiltration through the root zone. Five upper layers are used to represent the soil component of the root zone, and a lower, sixth layer is used to represent the geologic unit (either bedrock or unconsolidated deposits) underlying the soil zone (fig. $2 A$ ). All root-zone layers can have either uniform or variable thicknesses and are parameterized by using maps of geology, soils, and vegetation. The bottom of the root zone is the estimated maximum depthbelow-ground surface affected by ET.

INFILv3 uses a daily time step for simulating the water balance of the root zone and an hourly time step for simulating solar radiation and PET. The simulated daily water balance of the root zone includes precipitation (as either rain or snow), snow accumulation, sublimation, snowmelt, infiltration into the root zone, ET, percolation through the root zone, water-content changes for each root-zone layer, surfacewater runoff, and net infiltration from the root zone (defined as drainage from the bottom root-zone layer; fig. 2). PET is simulated by using an hourly time step to better represent the shading effects of rugged terrain relative to changes in solar position throughout the year (Flint and Childs, 1987). By using a modified form of the Priestley-Taylor equation (equations 10-14, U.S. Geological Survey, 2008), daily ET is simulated as a combined function of daily PET, the vertical distribution of available water in the root-zone layers, and the root-zone density, where the root-zone density represents the characteristics of vegetation. 
$\boldsymbol{A}$

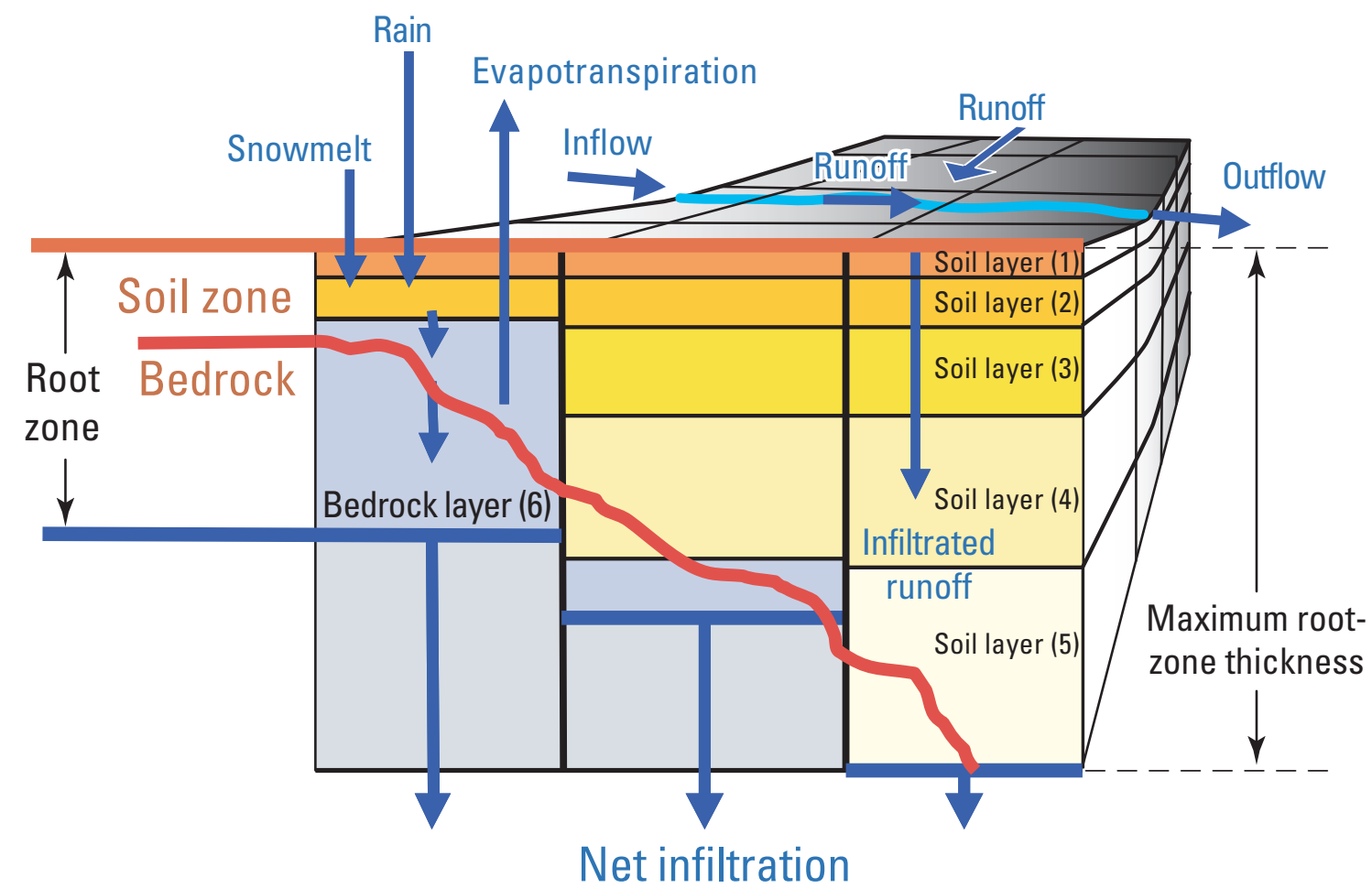

B

Evapotranspiration

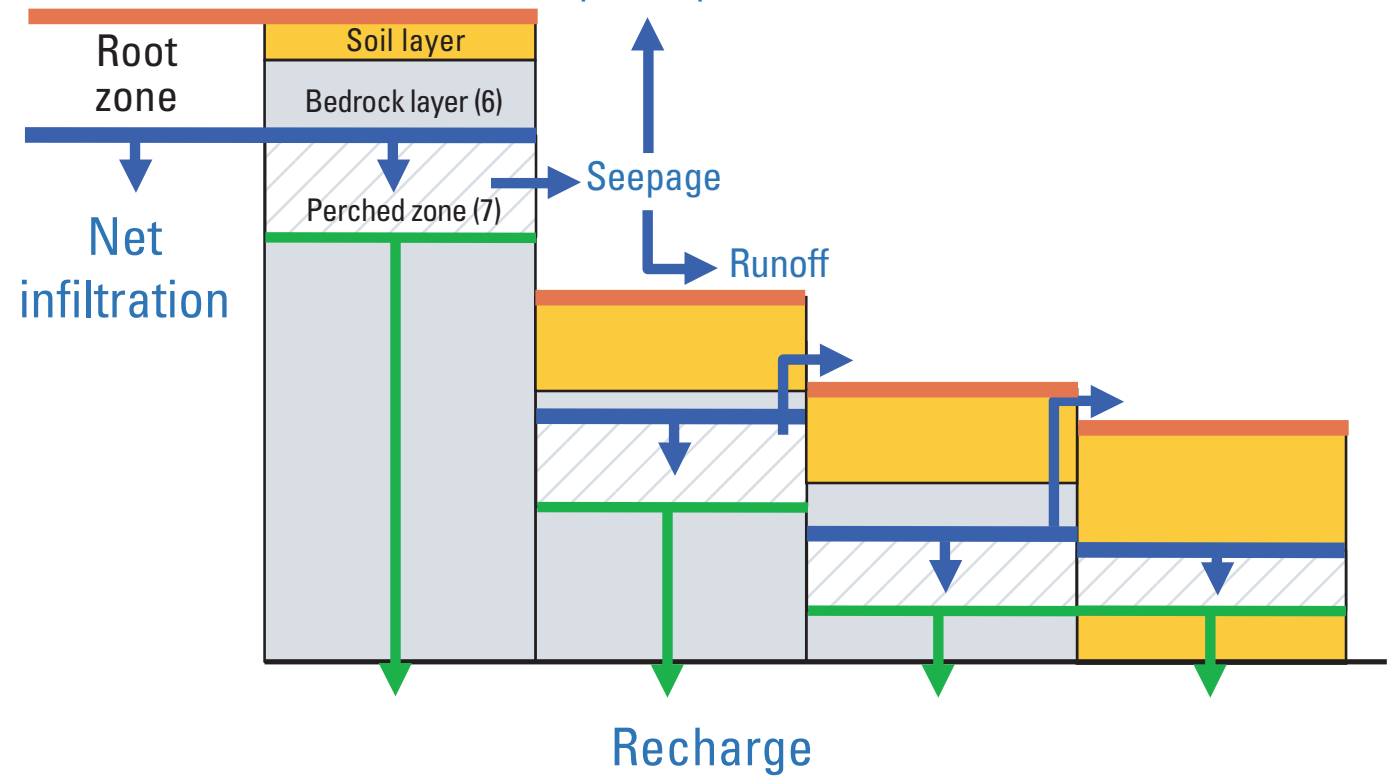

Figure 2. Representations of the soil zones by the INFILv3 code used for the San Gorgonio Pass watershed model, California, of $A$, the multi-layered root zone; and $B$, the perched zone. 


\section{Shallow Perched Groundwater Zone}

Following the approach used in Flint and Martin (2012), a modified version of the INFILv3 code was applied in this study in order to include a shallow perched-groundwater zone (layer 7) beneath the bottom layer of the root zone (fig. 2B). The shallow perched zone is used to partition net infiltration through the root zone into two separate flow components: (1) lateral flux (seepage) and (2) downward flux (recharge), with the lateral-flux component contributing to the inflows of the downstream cell (Flint and Martin, 2012). The amount of seepage flow is dependent on the water content of layer 7 , the land-surface slope, and the effective lateral hydraulic conductivity assigned to layer 7 . The amount of recharge is dependent on the water content of layer 7 after the calculation of seepage and on the effective vertical hydraulic conductivity assigned to layer 7 .

Seepage flow is considered to be potentially important in rugged mountainous areas with steep slopes (Flint and Martin, 2012). The inclusion of seepage flow allows for a portion of simulated net infiltration to flow laterally to the active root zone of the downstream grid cell. In general, the net effect of seepage flow is to reduce recharge for the upstream grid cell, while increasing ET for downstream cells. Recharge for downstream cells can also be increased in response to seepage flow. The increased seepage flow generally causes an increase in runoff during dry periods, which represents the baseflow component of streamflow. Lateral subsurface flow tends to cause more rapid drainage and, thus, drier antecedent conditions in the root zone of upstream cells, and this, in-turn, can reduce runoff.

\section{Model Development}

Development of the SGPWM by using the INFILv3 code was done by defining (1) the simulation period; (2) the initial conditions; (3) the model layout and spatial discretization; (4) the grid-cell parameters representing the physical characteristics of the model domain; (5) the climate inputs, consisting of daily climate records and model parameters for spatially interpolating daily precipitation and air temperature over the model domain; and (6) model coefficients.

\section{Simulation Period}

The target simulation period for the SGPWM was a continuous 100-year period, starting with water year 1913 and ending with water year 2012. The target simulation period was used to develop and analyze simulation results, including recharge and all components of the water budget. Simulations were started on January 1, 1909, to allow for a 45-month (3.75 year) model initialization period prior to the start of the target period. Precipitation-runoff models, including INFILv3, generally require at least some initialization period in order to help minimize uncertainties associated with the assumed or estimated initial conditions. A 1-year initialization period is considered adequate for modeled storage components (rootzone layers and snowpack storage) for study areas where measurable snow cover does not persist through the summer months (Markstrom and others, 2008). Previous INFILv3 applications for the San Gorgonio Pass study area indicated that a 3-year initialization period for the root-zone water content was sufficient to generate results independent of the initial conditions assumed for most locations (Rewis and others, 2006). The 45-month initialization period used in the SGPWM was assumed to be sufficient for reducing uncertainty associated with the initial conditions (see following section). The initialization period was excluded in the calculation of simulation results, such as the long-term average recharge and runoff rates.

\section{Initial Conditions}

Initial conditions consisted of the starting water contents of the root-zone layers (layers 1 through 6 ), of the perched zone (layer 7), and of the snowpack. Initial conditions for the SGPWM were made equivalent to initial conditions used in previous INFILv3 studies (Flint and Martin, 2012). The initial conditions consisted of an initial water content for soil layers in the root zone (layers 1 through 5) equal to 1.5 times the wilting-point water content. An initial water content of zero was assumed for root-zone layer 6 , for the perched zone (layer 7), and for the snowpack.

\section{Model Layout and Discretization}

Spatial discretization is used to represent the heterogeneity of the model domain and includes both horizontal and vertical discretization. With the INFILv3 code, horizontal discretization is defined by the grid-cell spacing, orientation, and extent. Vertical discretization is defined by the thickness of the seven model layers (six layers for the root zone and one layer for the perched zone), which can vary from cell to cell.

The INFILv3 code requires that the area modeled is discretized into a horizontal two-dimensional grid of equal-area (square) cells that are linked to create a cascading-flow routing network used to represent the mapped drainages and streamlines. The gridded discretization is similar to the approach used in other models, such as the Precipitation Runoff Modeling System (PRMS; Jeton and Maurer, 2011), Topmodel (Beven and Kirkbys, 1979), the Basin Characterization Model (BCM; Flint and Flint, 2007), and the Groundwater and Surface-water Flow model (GSFLOW; Markstrom and others, 2008; Hevesi and others, 2011; Woolfenden and Nishikawa, 2014). In addition to defining the streamlines, the gridded discretization is used to represent heterogeneities in climate and the physical characteristics of the watershed. Each cell in the two-dimensional grid represents a homogeneous hydrologic 
response unit. For the SGPWM, a grid-cell geometry of 150 by $150 \mathrm{~m}$ was used, aligned according to the Universal Transverse Mercator, zone 11 projection, North American Datum of 1983. The grid-cell size and geometry was selected to match the grid used for groundwater modeling of the SGPGSA.

The SGPWM model domain and layout are defined by the flow-routing connections, the watershed boundaries, and the model subdomains. The SGPWM model domain includes 30,595 active model cells covering an area of 68,832 hectares $\left(688.3 \mathrm{~km}^{2}\right)$ and consists of three separate subdomains. Gridcell connections defining the downstream cell for surfacewater and seepage-flow routing were developed by using a combination of grid-cell altitudes and mapped hydrographic features. The average grid-cell altitudes were defined in a geographic information system (GIS) by using a 10-m digital elevation model compiled from the National Elevation Dataset (NED, Gesch and others, 2009) obtained from http://nationalmap.gov/elevation.html. Initial flow directions defining the downstream cell were defined in GIS by using the standard eight-direction (D-8) routing method (Maidment, 2002). The D-8 "many-to-one" routing method specifies a single downstream cell for each grid cell, but a given cell can receive inflows from multiple upstream cells (to a maximum of eight). For some parts of the SGPWM, the flow directions were modified to provide a better match of the simulated drainage network to the mapped hydrography.

The total number of cells upstream of each cell, calculated in GIS by using the D-8 flow directions, was used to provide a visual representation of the SGPWM cascadingflow routing network (fig. 3). Locations with more than 200-upstream cells indicate the larger channels represented by the model, such as Noble Creek, San Timoteo Creek, Potrero Creek, Smith Creek, San Gorgonio River, and Snow Creek. Locations with 11 to 100 upstream cells indicate the smaller, first-order streams.

The three SGPWM subdomains represent the three topographically defined surface-water drainages, each with a single cell at the lowest altitude of the subdomain defining the location of all surface-water and seepage discharge. The San Gorgonio River (SGR) subdomain has 23,291 model cells and an area of 52,405 hectares (524 square kilometers), the San Timoteo Creek (STC) subdomain has 6,362 model cells and an area of 14,315 hectares (143 square kilometers), and the Potrero Creek (PTC) subdomain has 939 model cells and an area of 2,113 hectares (21 square kilometers; figs. 1A, 3).

The INFILv 3 code requires vertical discretization of the root zone into six layers, which are used to account for differences as a function of depth in root density, storage capacity, and vertical hydraulic conductivity. In addition to the six rootzone layers, the INFILv3 code used in the SGPWM includes a seventh layer that represents a perched zone beneath the root zone (Flint and Martin, 2012; fig. 2B). The seventh layer is used to simulate lateral flow in the unsaturated zone, referred to in this study as seepage flow. The model version used in the previous INFILv3 recharge study (Rewis and others, 2006) did not include a seventh layer or a seepage-flow component. In the INFILv3 version used in the SGPWM, seepage flow is routed from upstream to downstream cells by using the same D-8 cascade-routing network used for surface-water runoff (Flint and Martin, 2012).

The vertical discretization enables the simulation of differences in the root-zone water content and ET as a function of depth and allows for the representation of differences in the characteristics of the root zone between soil and bedrock. Model layers 1 through 5 represent the soil-zone component of the root zone, whereas the sixth model layer represents consolidated bedrock for locations with thin soils. For locations with thick soils, layer 6 can have a thickness of zero; however, net infiltration through the root zone is limited by the vertical hydraulic conductivity defined for layer 6 . The layer 6 vertical hydraulic conductivity is used to represent the permeability of unconsolidated geologic units underlying the soil component of the root zone.

The model layers are assigned a storage capacity and a vertical hydraulic conductivity. The storage capacity is calculated by using an estimated porosity and layer thickness for each cell (Rewis and others, 2006; U.S. Geological Survey, 2008, Flint and Martin, 2012). For a given cell, a layer can be assigned a thickness of zero, in which case the storage capacity of the layer is also zero. The layer thicknesses are determined on the basis of the total estimated root-zone and soil thicknesses, which, in turn, are estimated by using a combination of vegetation, soil, and geology maps. For this study, root-zone layer thicknesses were based on the Rewis model in the Beaumont and Banning subbasins (Rewis and others, 2006) and were extended to the Cabazon and Indio subbasins. A more detailed discussion of layer thicknesses defined for the SGPWM is given in the following section.

\section{Grid-Cell Parameters}

Grid-cell parameters defining the physical characteristics of watersheds, including the land surface, the underlying root zone, and the shallow perched zone beneath the root zone, can be grouped into parameters representing (1) topography, (2) land cover, (3) soils, (4) geology, and (5) soil and rootzone layer thicknesses. These parameters were estimated for all model grid cells by using GIS and preprocessing routines.

\section{Topography}

The 10-m resolution USGS NED data (Gesch and others, 2009) used in the development of the flow-routing network also was used to define topographic parameters used to simulate PET. The parameters used to simulate PET include cell altitude, slope, aspect, the sky view parameter (used to simulate incoming solar radiation), and a set of 36 blocking ridge angles (used to simulate the effects of shading on PET in rugged areas; U.S. Geological Survey, 2008). 


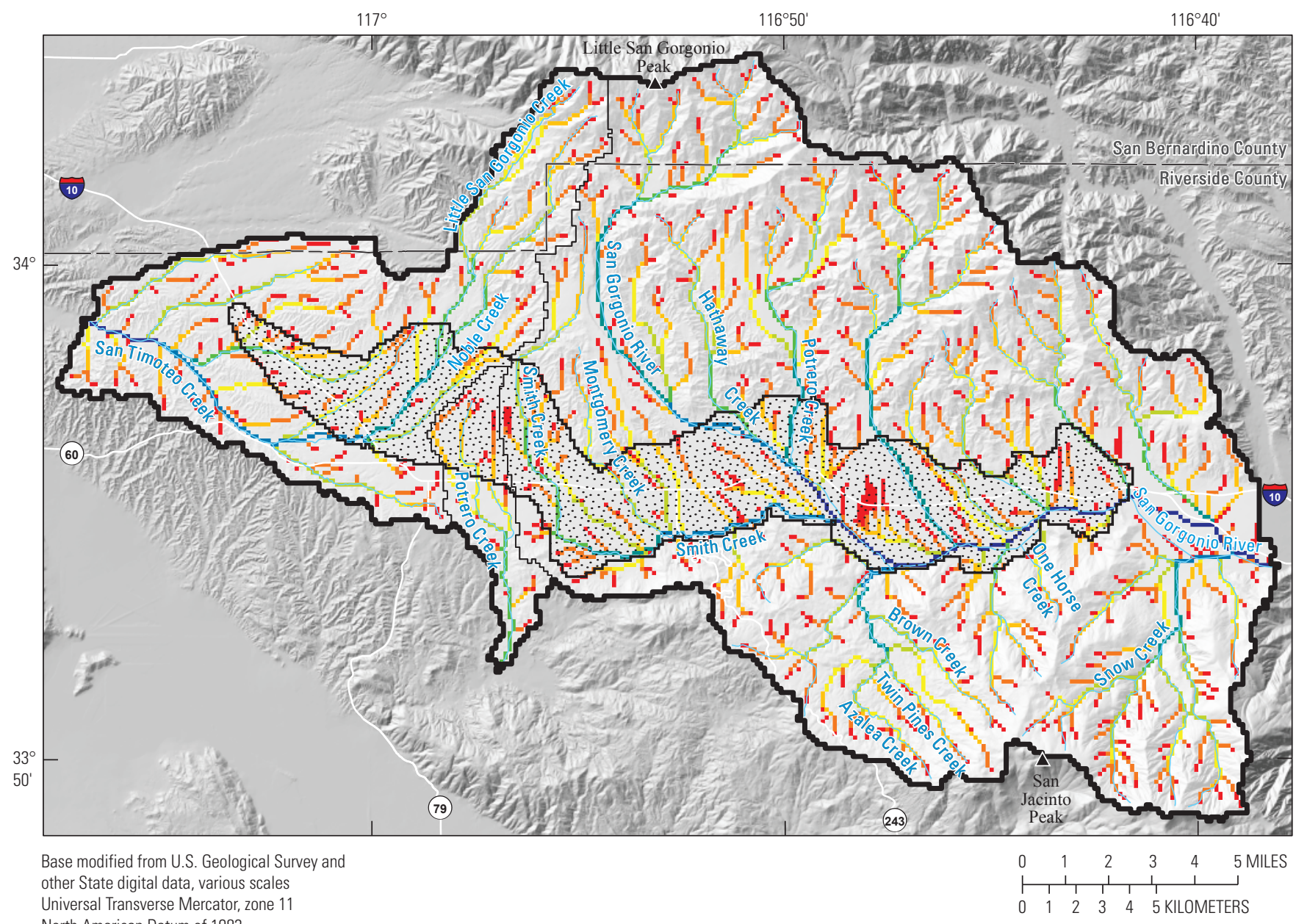

al Transverse Mercator, zone 11 North American Datum of 1983

EXPLANATION
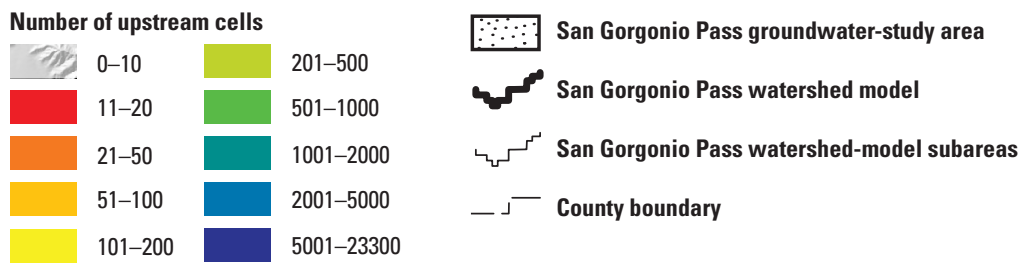

Figure 3. Number of upstream cells indicating the cascade flow-routing network for the San Gorgonio Pass watershed model, California.

Grid-cell altitudes for the SGPWM range from a minimum of $332 \mathrm{~m}$ along the eastern boundary, in the Indio subbasin, to a maximum of 3,293 $\mathrm{m}$ at the summit of San Jacinto Peak (fig. $1 A$ ). The average altitude for the SGPWM is $1,059 \mathrm{~m}$. The SGR subdomain has the highest average altitude at $1,108 \mathrm{~m}$, and the PTC subdomain has the lowest average altitude at $784 \mathrm{~m}$. The SGPGSA includes the lowest altitudes in the SGPWM, having an average altitude of $740 \mathrm{~m}$, a maximum altitude of $960 \mathrm{~m}$, and a minimum altitude of $332 \mathrm{~m}$.

Average grid-cell slope was defined by calculating the slope in degrees of the10-m NED grid and, then, calculating the average $10-\mathrm{m}$ NED slope in the area of each cell. The calculated average slope for the SGPWM is 12 degrees in the SGPGSA, with a maximum slope of 50 degrees for a cell on the upper northern slope of San Jacinto Peak and a minimum slope of zero degrees for a cell on the valley floor, (fig. 4). The SGR subdomain has the highest average slope at 14 degrees, and the PTC subdomain has the lowest average slope at 3 degrees.

Grid-cell aspect is the direction of maximum slope and was defined as the majority aspect value of the 10-m digital elevation model in the area of each cell. The northern part of the SGPWM includes the southern part of the San Bernardino Mountains and is dominated by southeast, south, and southwest facing aspects, whereas, the southern part of the SGPWM includes the northern part of Mount San Jacinto and is dominated by north, northeast, and northwest facing aspects. In the SGPGSA, southeast, south, and southwest aspects are the most prevalent. 


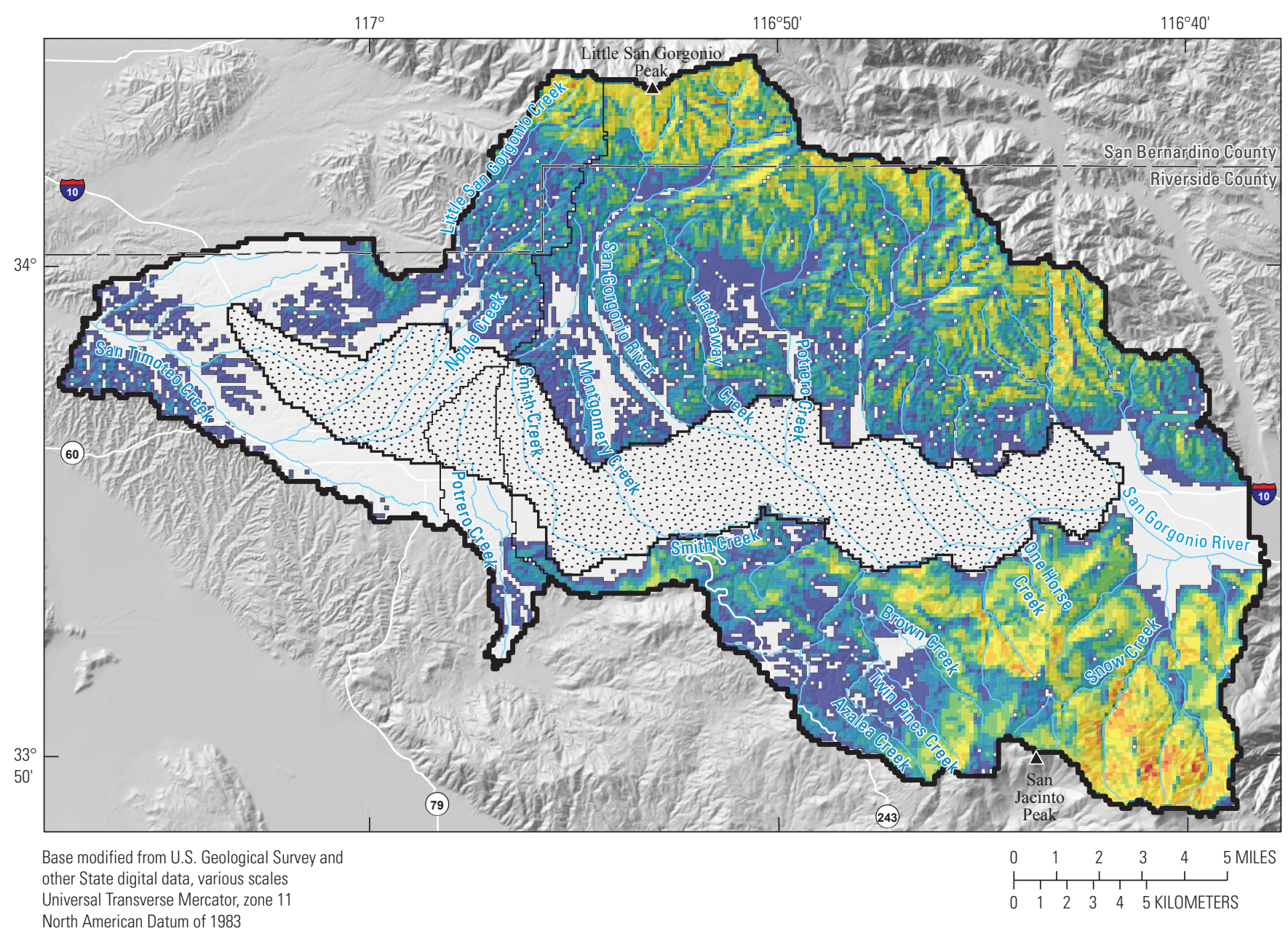

EXPLANATION

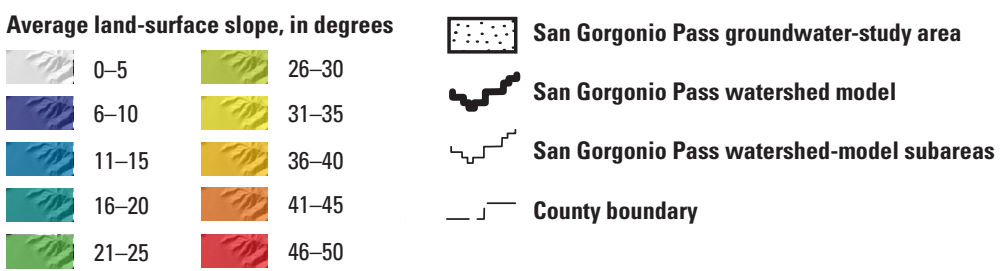

Figure 4. Calculated land surface slope used in the San Gorgonio Pass watershed model, California.

In addition to slope and aspect, shading and reflection of sunlight from surrounding terrain can have a big effect on calculated PET (Flint and Childs, 1987). To account for the shading effect of surrounding terrain, model input includes 36 blocking-ridge angles that were calculated at each 10-degree azimuth direction by using methods described in Hevesi and others (2003). In general, simulated PET is lowest for steep, north-facing valleys and gullies that have persistent shading from higher ridges and is highest for south-facing slopes and ridges not affected much by shading from surrounding topography.

\section{Land Cover}

Three land-cover parameters are used in the SGPWM: (1) percent imperviousness, (2) percent canopy cover, and (3) land cover type. The percentage of imperviousness and of canopy cover were estimated by using the 2001 National Land Cover Data (NLCD), which has a grid resolution of $30 \mathrm{~m}$ (Homer and others, 2007). Land-cover type was defined by using the "whrtyp" attribute of the California Land Cover Mapping and Monitoring Program (LCMMP; California Department of Forestry and Fire Protection, 2002). 
The NLCD percent imperviousness is defined as the percentage of the cell area that is covered by an artificial, impervious surface such as roadways, rooftops, and parking lots. As used in the SGPWM, imperviousness does not represent locations that have relatively low permeability caused by exposed bedrock or by thin soils underlain by bedrock. The average imperviousness for each model cell was calculated in GIS. The average imperviousness for the SGPWM was about 2 percent. About 85 percent of the cells in the SGPWM had an imperviousness value of 0 to 1 percent (fig. 5). Only about 1 percent of the cells had imperviousness of 50 percent or greater. The maximum imperviousness value was 71 percent per cell and was in the valley of the Cabazon subbasin. In general, the areas with greater imperviousness ( 20 percent and more) were along the main roadways and were indicative of areas characterized by urbanization and land development.

Estimates of the average percentage of canopy cover for the SGPWM were also calculated in GIS. The percentage of canopy cover represented by NLCD is defined as the percentage of the cell area covered by natural forest canopy. The NLCD forest canopy map does not represent vegetation cover for urban or agricultural landscapes. A maximum forest canopy cover of 83 percent was calculated for a model cell on an upper north-facing slope of Little San Gorgonio Peak, and

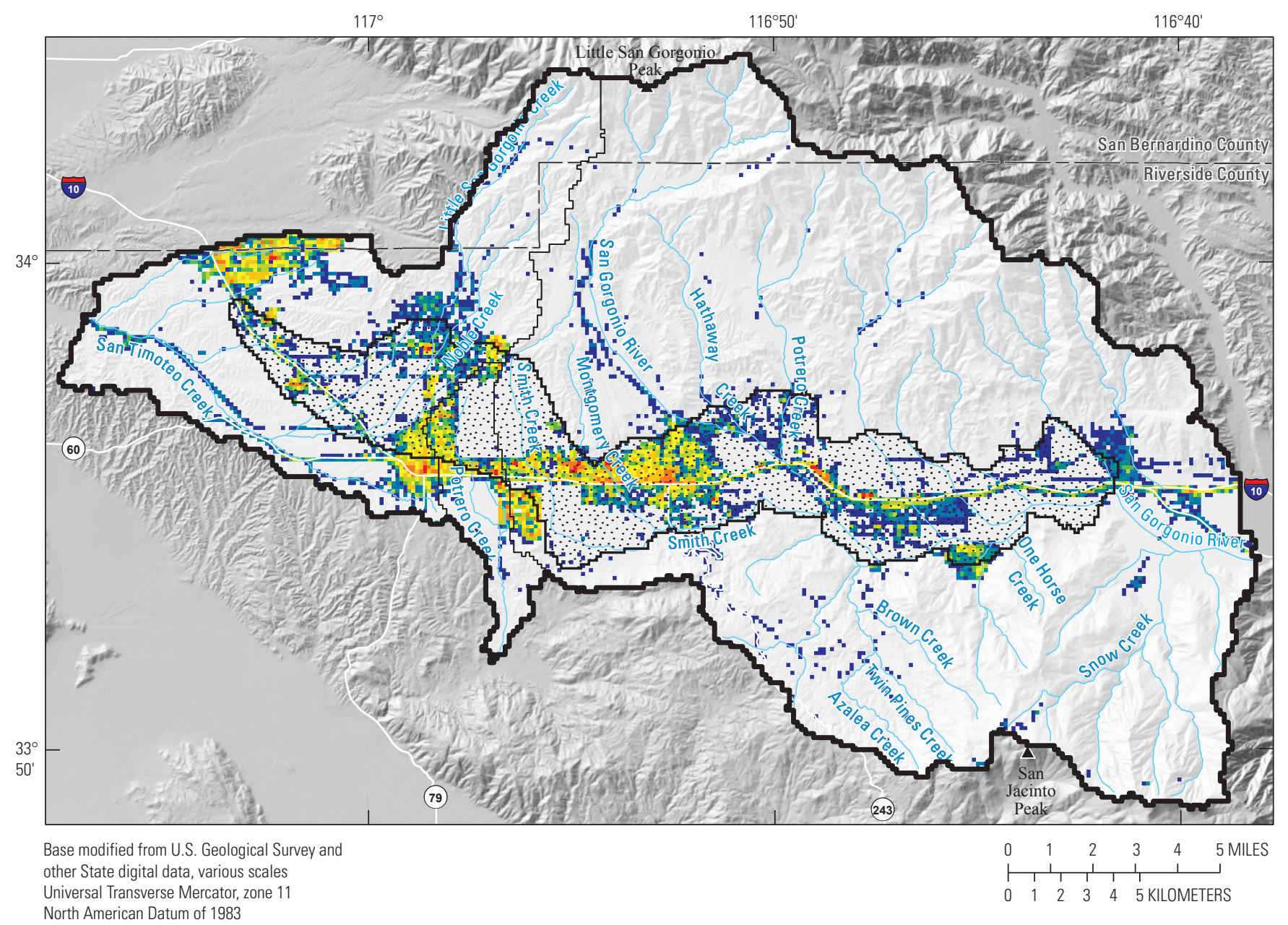

EXPLANATION
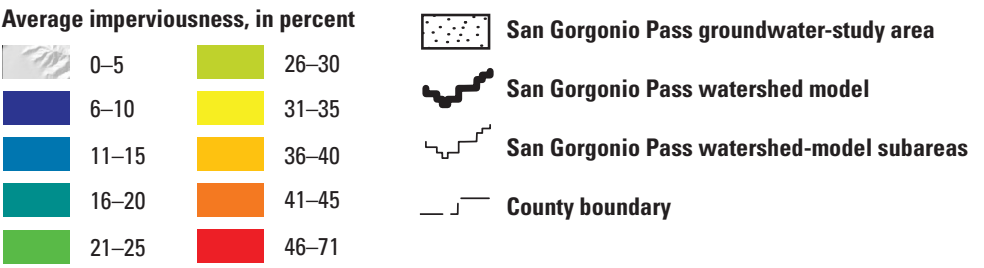

Figure 5. Percent impervious area, defined as the percentage of the cell area that is covered by an artificial surface such as roadways, rooftops, and parking lots, used in the San Gorgonio Pass watershed model, California. 
an average value of 9.4 percent was calculated for the entire SGPWM domain. Forest canopy values of 0 percent were obtained for most of the developed and urbanized lowland areas and throughout the SGPGSA.

A total of 28 different land-cover types were identified for the SGPWM by using the LCMMP (fig. 6; table 1). Estimated root densities for soil layer 2 , which had a maximum estimated thickness of $0.4 \mathrm{~m}$, ranged from high values of 97 percent for
Ponderosa Pine and for White Fir, and 82 percent for Sierran Mixed Conifer, to low values of 8 percent for barren ground, 28 percent for annual grass, and 44 percent for sagebrush. Estimated root densities for soil layer 5, which had a maximum estimated thickness of $4 \mathrm{~m}$, varied from maximum values of 68 percent for Ponderosa Pine and White Fir to minimum values of 6 percent for desert scrub, barren ground, and annual grass.

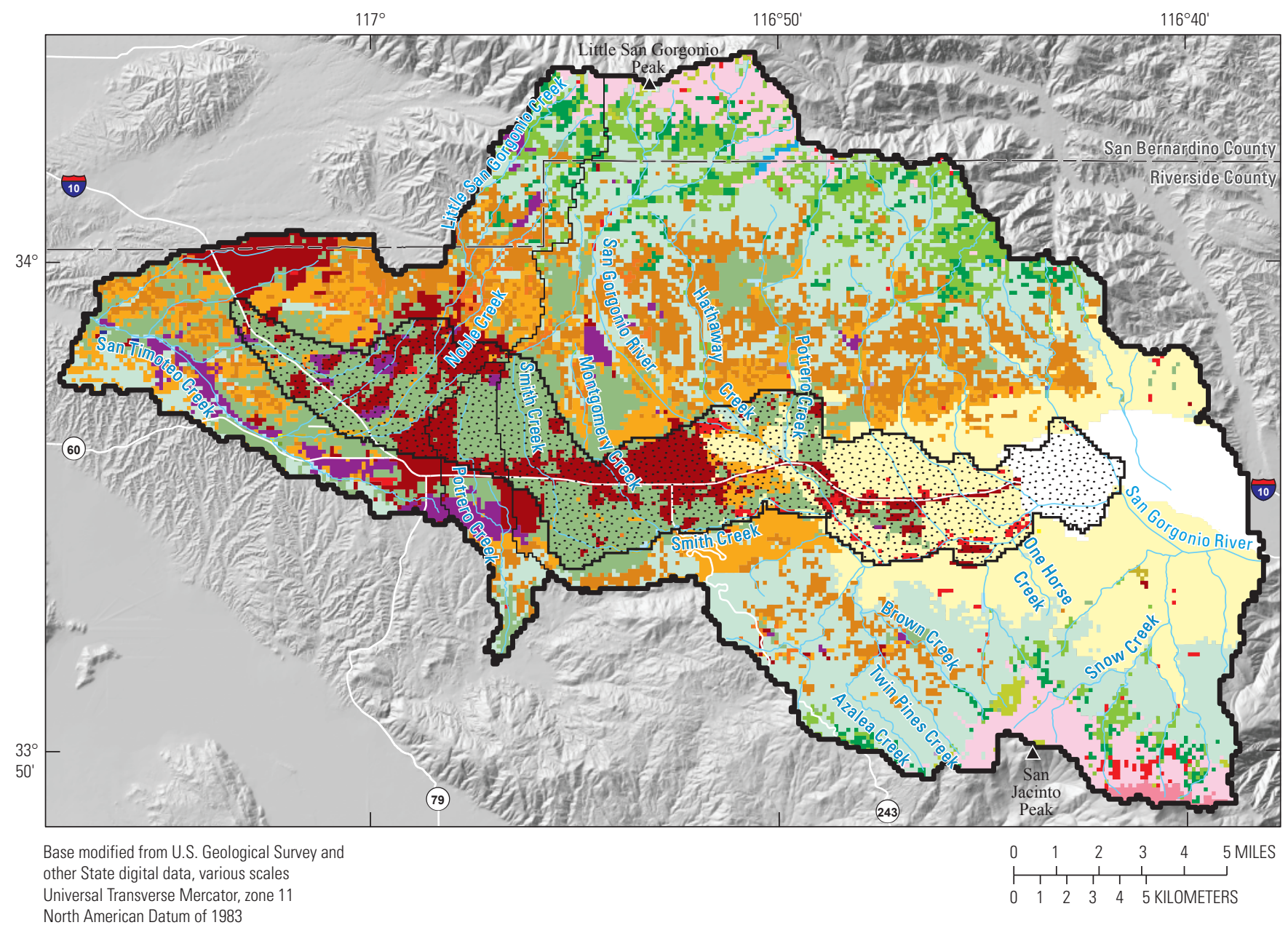

EXPLANATION

\begin{tabular}{|l}
\hline Dominant vegetation type \\
\hline Agricultural crops \\
\hline Annual grass \\
\hline Barren \\
\hline Chamise-redshank chaparral \\
Coastal oak woodland \\
\hline Coastal scrub \\
\hline Desert riparian \\
\hline Desert scrub \\
Desert wash \\
Eucalyptus
\end{tabular}
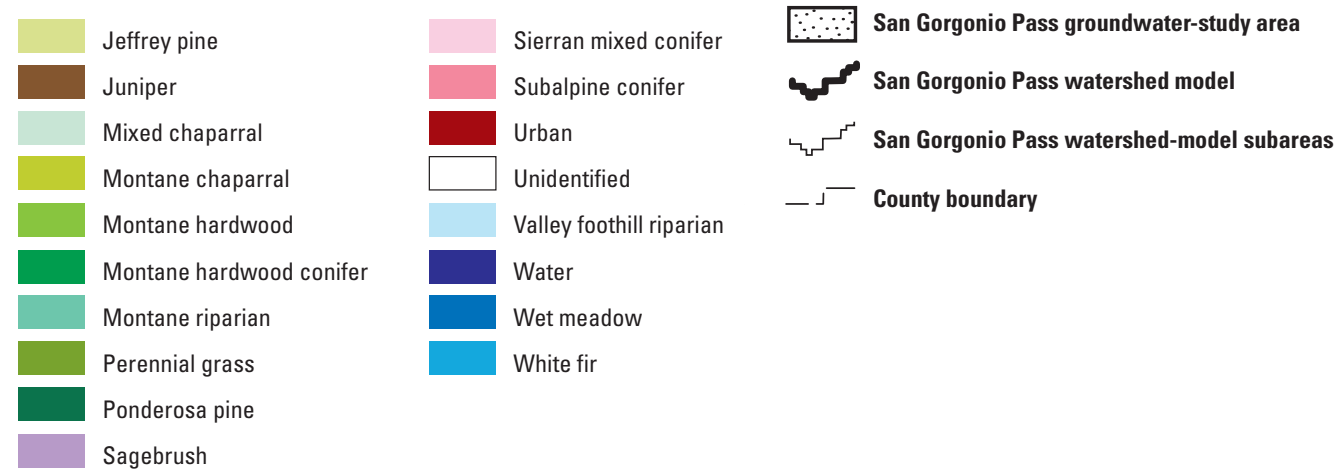

Figure 6. Land-cover type, San Gorgonio Pass watershed model, California. 
Table 1. Vegetation parameters used in the San Gorgonio Pass watershed model, California.

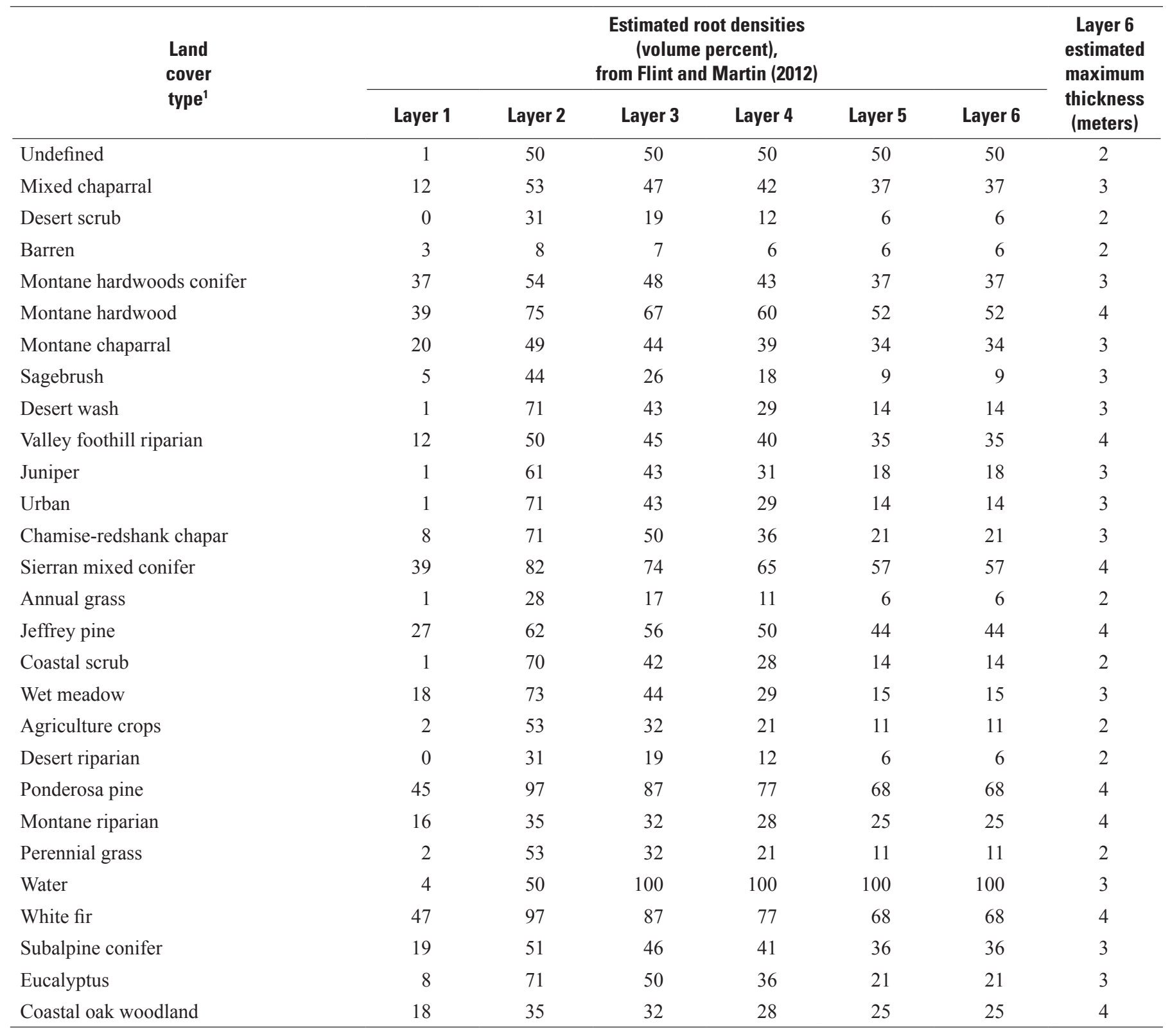

${ }^{1}$ From California Land Cover Mapping and Monitoring Program (LCMMP) Geographic Information System data (http://frap.cdf.ca.gov/projects/land_cover/ index.html). 


\section{Soil}

Soil parameters were estimated for each model cell by using the State Soil Geographic Database (STATSGO) digital map and associated attribute tables (U.S. Department of Agriculture,1994). A total of 10 different soil types, or soil map units (MUIDs) as defined by STATSGO, are included in the SGPWM (fig. 7; table 2). Soil parameters calculated by using the STATSGO data include soil porosity, residual water content, a drainage function coefficient, and an upper and lower vertical saturated hydraulic conductivity (Hevesi and others, 2003). Porosity and residual water content is used with the estimated soil depth to define the root-zone storage capacities for the five soil layers. For the SGPWM, soil porosities varied from a minimum of 0.35 to a maximum of 0.43 . The soil drainage function coefficients and the vertical saturated hydraulic conductivities are used in the drainage and ET calculations for the soil component of the root zone. For the SGPWM, the saturated hydraulic conductivities ranged from a minimum of 179 millimeters per day ( $\mathrm{mm} /$ day) for soil CA624 to a maximum of $7,376 \mathrm{~mm} /$ day for soil CA601 on the valley floor of the Indio subbasin, on the eastern side of the SGPWM (fig. 7; table 2).

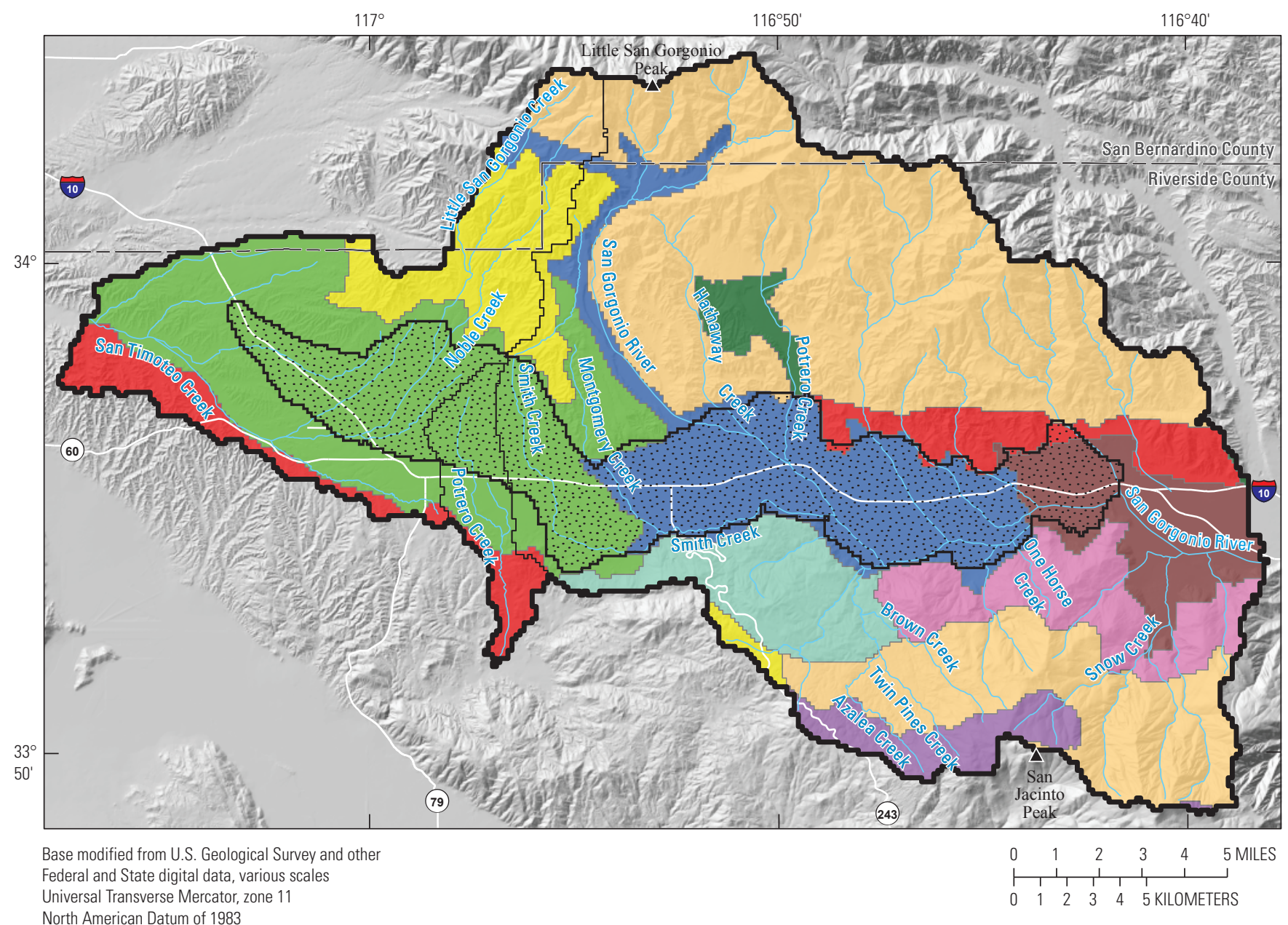

Universal Transverse Mercator, zor North American Datum of 1983

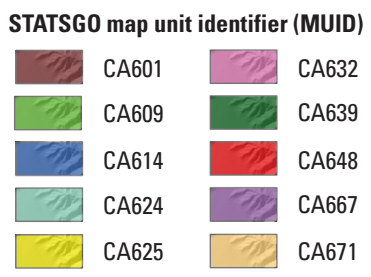

EXPLANATION

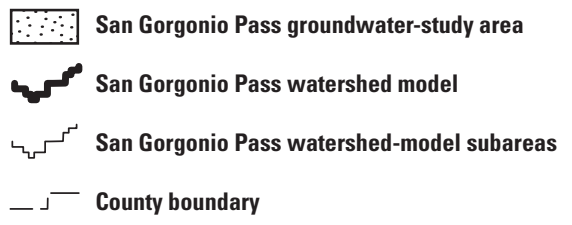

Figure 7. State Soil Geographic Database (STATSG0) soil map units used in the San Gorgonio Pass watershed model, California. 
Table 2. Soil parameters developed from State Soil Geographic Database (STATSG0) soil map units, root-zone layers 1-5, San Gorgonio Pass watershed model, California.

\begin{tabular}{|c|c|c|c|c|c|}
\hline \multirow{2}{*}{$\begin{array}{l}\text { STATSGO } \\
\text { map-unit } \\
\text { identifier }^{1} \\
\text { (MUID) }^{2}\end{array}$} & \multicolumn{5}{|c|}{ Estimated parameter values } \\
\hline & $\begin{array}{c}\text { Soil } \\
\text { Porosity }\end{array}$ & $\begin{array}{l}\text { Residual } \\
\text { water } \\
\text { content }\end{array}$ & $\begin{array}{c}\text { Drainage } \\
\text { function } \\
\text { coefficient }\end{array}$ & $\begin{array}{c}\text { Layer } 6 \text { lower } \\
\text { hydraulic conductivity } \\
\text { (millimeters/day) }\end{array}$ & $\begin{array}{c}\text { Layer } 6 \text { upper } \\
\text { hydraulic conductivity } \\
\text { (millimeters/day) }\end{array}$ \\
\hline CA667 & 0.35 & 0.030 & 4.21 & 752 & 4,655 \\
\hline${ }^{3} \mathrm{CA} 639$ & 0.36 & 0.026 & 3.71 & 919 & 5,026 \\
\hline CA671 & 0.43 & 0.014 & 3.54 & 977 & 4,780 \\
\hline${ }^{3} \mathrm{CA} 648$ & 0.37 & 0.067 & 5.33 & 385 & 1,196 \\
\hline${ }^{3} \mathrm{CA} 609$ & 0.36 & 0.070 & 5.73 & 363 & 925 \\
\hline${ }^{3} \mathrm{CA} 625$ & 0.37 & 0.031 & 3.89 & 936 & 2,728 \\
\hline${ }^{3} \mathrm{CA} 624$ & 0.38 & 0.103 & 7.18 & 179 & 923 \\
\hline
\end{tabular}

${ }^{1}$ State Soil Geographic database, U.S. Department of Agriculture, 1994, State Soil Geographic (STATSGO) Data Base-Data use information: Natural Resource Conservation Service, Miscellaneous Publication no. 1492: Soil Survey Staff, Natural Resources Conservation Service, United States Department of Agriculture U.S. General Soil Map (STATSGO) for California.

${ }^{2}$ MUID is the mapped area and identifier used by STATSGO.

${ }^{3}$ Gray shading indicates values for porosity, residual water content, and drainage function coefficient that are the same as in Rewis and others (2006). Layer 6 residual water content is wilting point in Rewis and others (2006). Lower hydraulic conductivity is approximately one tenth of the values in Rewis and others (2006).

\section{Geology}

Parameters for layers 6 and 7 are used to represent the properties of geologic materials (consolidated and unconsolidated rock types) underlying the soil zone and were estimated for each of the five generalized geologic types defined for the SGPWM (table 3; fig. 8). The generalized geologic types were based on the surficial-geology map units defined by Jennings (1977). The parameters for layer 6 are the effective porosity and upper and lower saturated hydraulic conductivity (table 3 ). The parameters for layer 7 are the thickness (table 3 ) and two drainage function coefficients. In this study, the drainage function coefficients were set to one for all geologic types. Estimates of effective porosity and upper and lower saturated hydraulic conductivity for layer 6 were based on a general knowledge of the characteristics of the different geologic units (Rewis and others, 2006). For example, unconsolidated deposits were assumed to have greater effective porosity and saturated hydraulic conductivity compared to consolidated rocks, and sedimentary rocks were assumed to have greater saturated hydraulic conductivity relative to igneous and metamorphic rocks. Following a previous application of the modified INFILv3 code (Flint and Martin, 2012), the thickness of layer 7 was defined by assuming a water-storage capacity of $0.6096 \mathrm{~m}$ ( 24 inches) and by using the estimated effective porosity defined for layer 6 to calculate a thickness for layer 7 . For example, if the effective porosity for layer 6 is 0.1 , the thickness of layer 7 needs to be 240 inches in order to have a storage capacity of 24 inches.
Table 3. Geologic parameters assigned to root-zone layers 6 and 7, San Gorgonio Pass watershed model, California.

\begin{tabular}{|c|c|c|c|}
\hline \multirow[b]{2}{*}{$\begin{array}{c}\text { Surficial } \\
\text { geology } \\
(\text { fig. 8) }\end{array}$} & \multirow[b]{2}{*}{$\begin{array}{l}\text { Layer } 6 \\
\text { effective } \\
\text { porosity }^{2}\end{array}$} & \multicolumn{2}{|c|}{ Estimated model parameters } \\
\hline & & $\begin{array}{c}\text { Layer } 6 \text { upper and } \\
\text { lower saturated } \\
\text { hydraulic conductivity } \\
\text { (millimeters/day) }\end{array}$ & $\begin{array}{c}\text { Layer } 7 \\
\text { thickness } \\
\text { (meters) }\end{array}$ \\
\hline Mixed sediments & 0.35 & 100 & 3.4 \\
\hline Alluvium & 0.35 & 50 & 3.4 \\
\hline $\begin{array}{l}\text { Continental } \\
\text { sediments }\end{array}$ & 0.25 & 25 & 4.8 \\
\hline Cretaceous granite & 0.05 & 0.5 & 24.0 \\
\hline $\begin{array}{l}\text { Precambrian } \\
\text { mixed rock, } \\
\text { metamorphic } \\
\text { rocks }\end{array}$ & 0.05 & 0.25 & 24.0 \\
\hline
\end{tabular}

${ }^{1}$ Jennings, C.W., 1977, Geologic map of California: California Division of Mines and Geology Geologic Data Map no. 2, scale 1:750,000.

${ }^{2}$ Layer 6 porosity from Rewis and others (2006). 


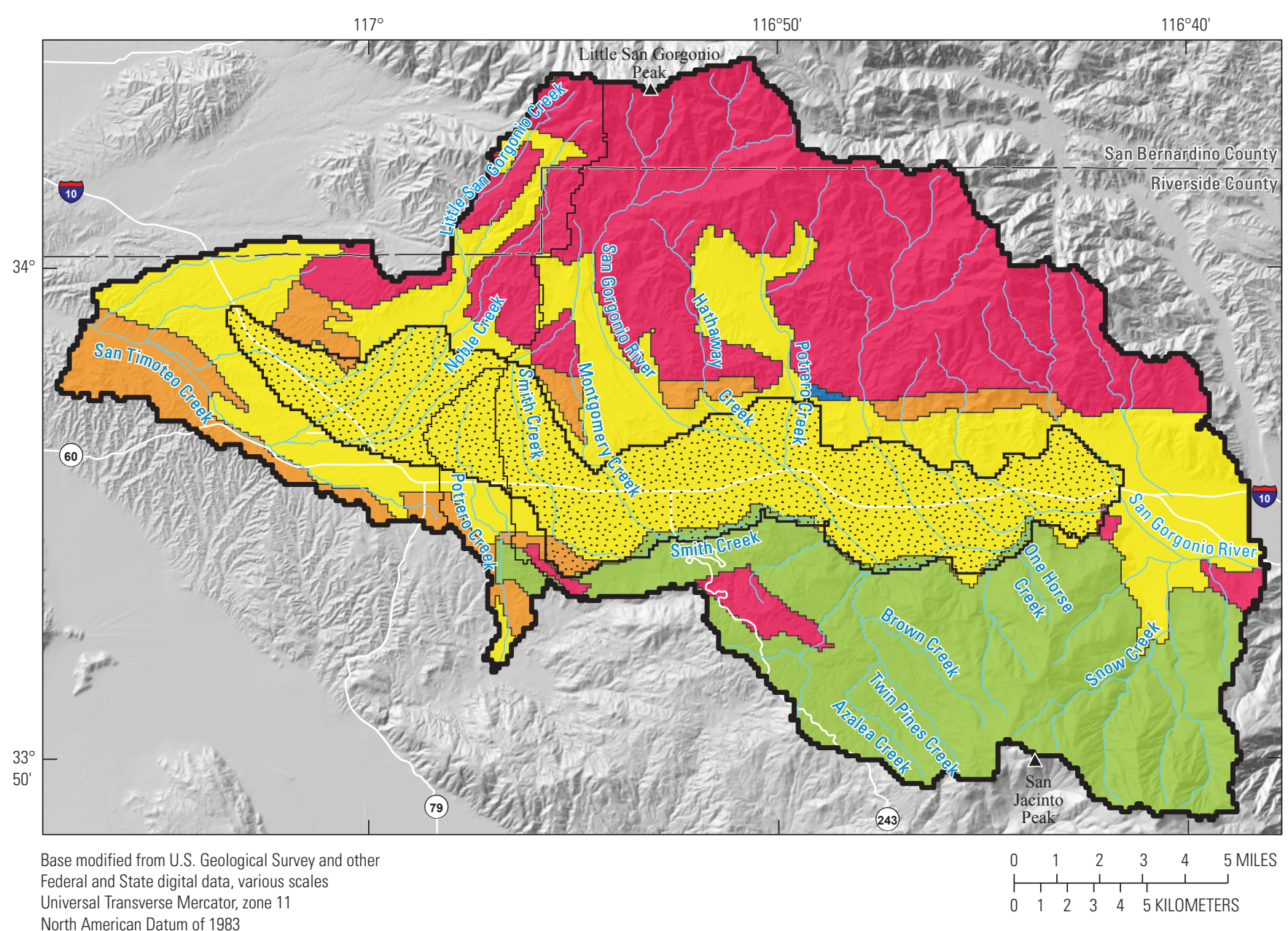

North American Datum of 1983

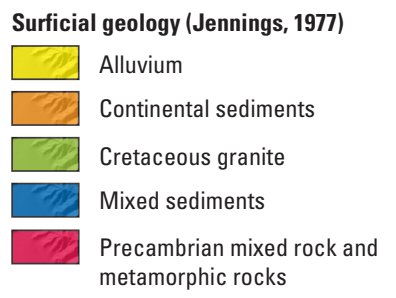

EXPLANATION

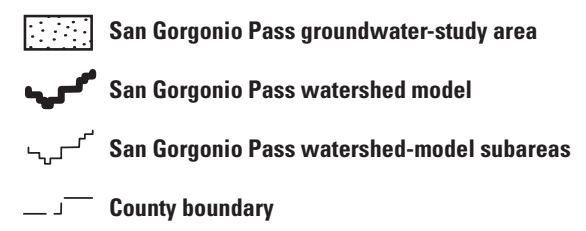

Figure 8. Surficial geology used in the San Gorgonio Pass watershed model, California.

\section{Soil and Root-Zone Layer Thicknesses}

Soil thickness (fig. 9) was estimated by using surficial geology (fig. 8) and the STATSGO soils data (fig. 7). Locations with thick soils (greater than $3 \mathrm{~m}$ ) were defined by using the unconsolidated alluvium geology type. Soil thickness was increased for all grid cells representing important channels. Cells having a minimum of 100 upstream cells (fig. 3) were assumed to represent important channels and were assigned a maximum soil thickness of $7.5 \mathrm{~m}$ for channels in alluvium. The increased soil thickness for stream channels was done to represent deeper root zones that were assumed for locations receiving runoff from upstream areas. Additionally, the increased soil thickness assigned for channels in upland areas that had surficial geology consisting of consolidated rock types was done to represent narrow bands of alluvial fill in upland channels.

Root-zone layer 6 is a layer that extends below the soil zone and is used mostly to represent the extension of the root zone into weathered and fractured consolidated-rock types (fig. 10). Layer 6 can also be used to represent the extension of the root zone into unconsolidated deposits in areas that have thick soils; however, the thickness of layer 6 is generally set to zero for these locations. The thickness for layer 6 was estimated on the basis of soil thickness and vegetation type (fig. 6). If the soils are thin and vegetation is dense (for example, mountain forested areas), layer 6 is thick (less than or equal to $7.5 \mathrm{~m}$ ). For areas underlain with thick alluvium 


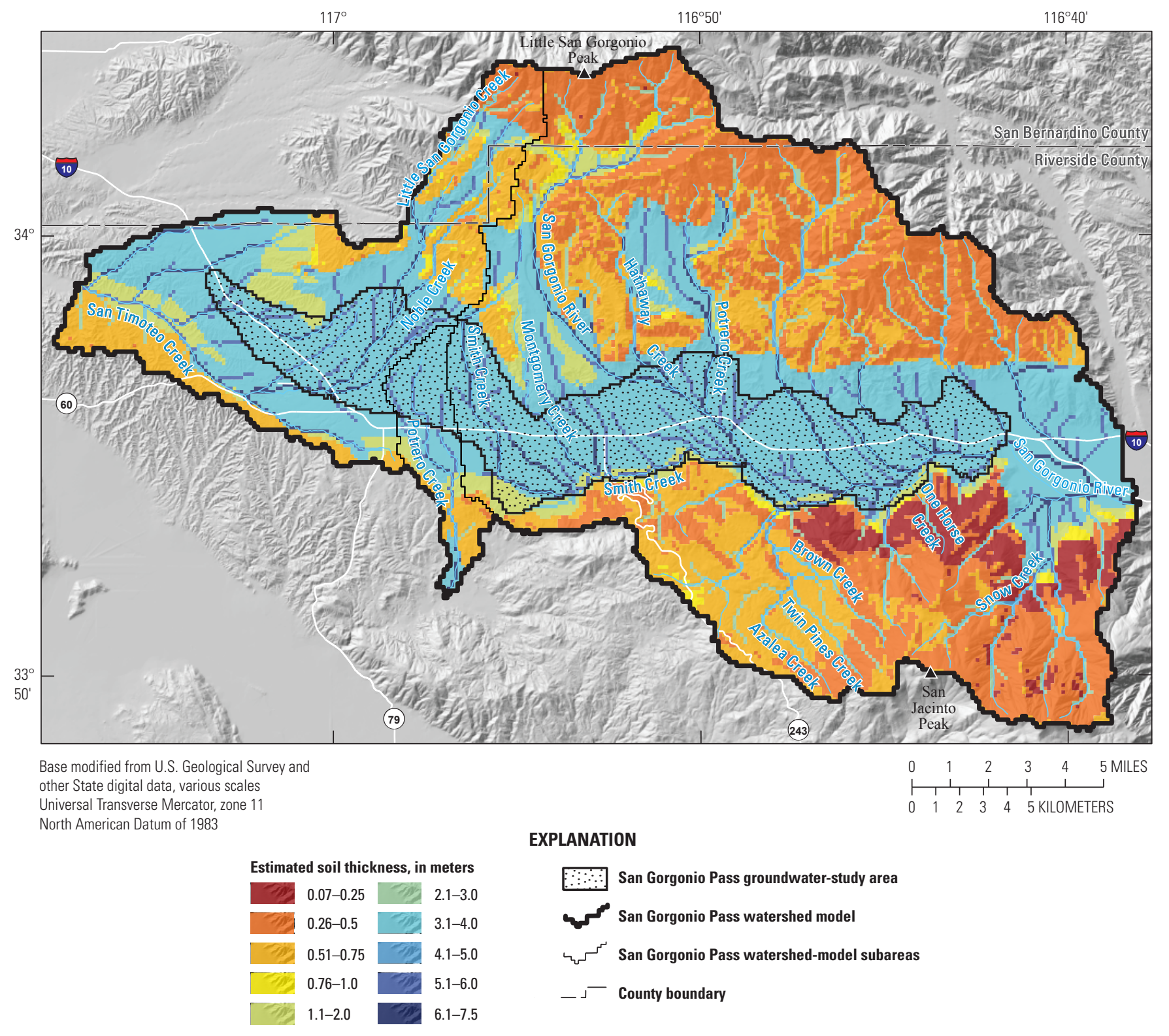

Figure 9. Estimated soil thickness used in the San Gorgonio Pass watershed model, California. 


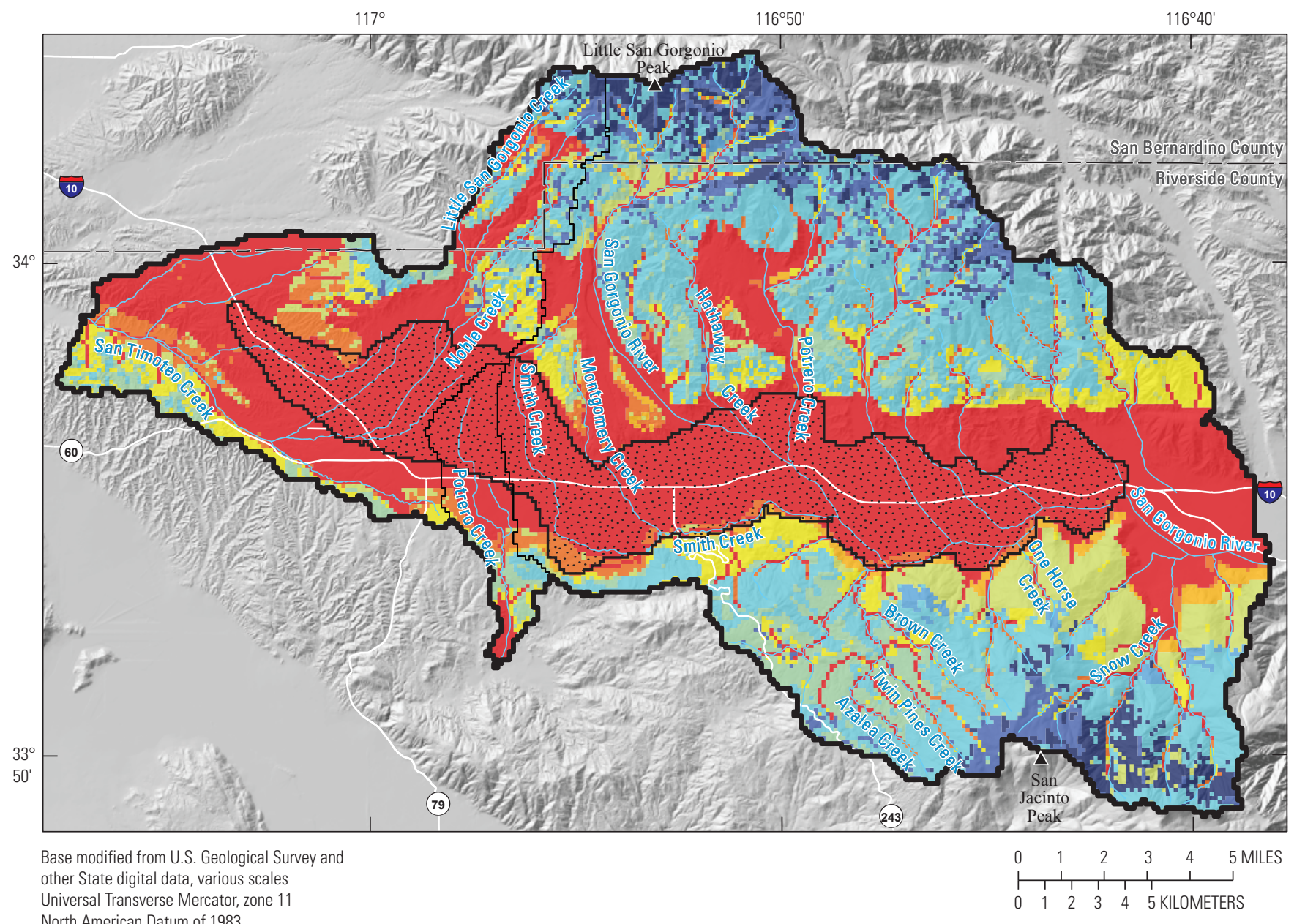

Universal Transverse Mercator, zone 11 North American Datum of 1983

\section{EXPLANATION}
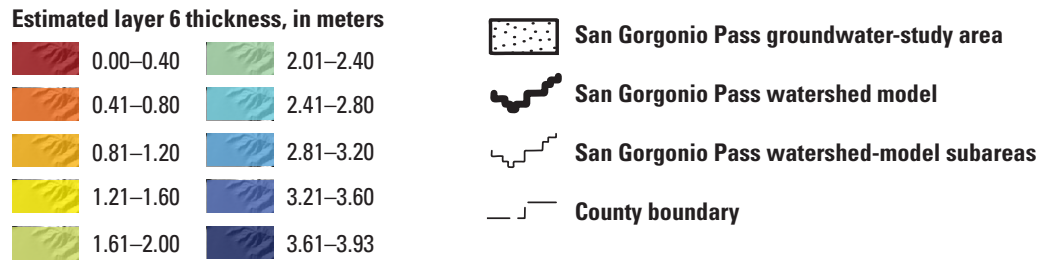

Figure 10. Estimated layer 6 thickness used in the San Gorgonio Pass watershed model, California.

(fig. 8), a maximum soil thickness of $7.5 \mathrm{~m}$ was used, and the thickness of layer 6 was set to zero (Rewis and others, 2006). Transpiration was simulated in only the five top-most soil layers, and layer 6 was used only to define the saturated hydraulic conductivity at the bottom of the root zone for the areas with thick alluvium.

The total root-zone thickness is the combined thickness of layers 1 through 6 , and it was assumed to vary from a minimum of $2.0 \mathrm{~m}$ to a maximum of $7.5 \mathrm{~m}$ for grid cells representing the main channels. The total root-zone thickness ranged from 3.2 to $3.5 \mathrm{~m}$ for the intra-channel locations throughout the lowlands and valley floor mapped as unconsolidated alluvium. These locations had five soil layers representing the root zone, and layer 6 was assigned a thickness of zero m. For upland areas underlain by consolidated rock types, the total root-zone thickness ranged from
$2 \mathrm{~m}$ throughout the lower altitudes of the mountain blocks, where vegetation cover is sparse, to more than $3.8 \mathrm{~m}$ at locations mapped as having forest cover (generally the higher altitudes of the mountain blocks). The root-zone thickness for the non-forested locations of the upland areas varied from 2.9 to $3.2 \mathrm{~m}$.

The total root-zone storage capacity is calculated by using the porosity and thickness of the six root-zone layers, and it defines the maximum water-storage capacity of the root zone. The total root-zone storage capacity is an important component of the SGPWM; more runoff tends to be simulated for grid cells that have less storage capacity, whereas more ET tends to be simulated for grid cells with more storage capacity. Recharge can either increase or decrease, depending on the hydraulic conductivity of layer 6 . The highest root-zone storage capacities of 2,510 to $3,080 \mathrm{~mm}$ were estimated for 
the main channels, where the thickest root zones and highest porosities were defined. High storage capacities of 1,000 to 2,000 $\mathrm{mm}$ also were estimated for the intra-channel areas mapped as having thick soils underlain by unconsolidated alluvium. Storage capacities were much less for the upland areas underlain by metamorphic rocks and granite, ranging from a minimum of $125 \mathrm{~mm}$ to a maximum of $600 \mathrm{~mm}$.

\section{Climate Inputs}

Climate inputs used for the SGPWM consist of three components: (1) daily climate records for precipitation, maximum air temperature, and minimum air temperature from a network of climate stations centered over the SGPWM; (2) estimates of average monthly precipitation and maximum and minimum air temperature for all model cells and all climate stations; and (3) atmospheric parameters used in simulating daily PET.

\section{Daily Climate Records}

Daily climate inputs were developed by using available climate records. The SGPWM requires that the daily climate records consist of a minimum of two records of precipitation and one record each for maximum and minimum air temperature for all days of the simulation period. Daily climate records (precipitation and air temperature) were available from a network of 134 climate stations in the southern California region centered on the SGPWM (table 4). Of these, records from 112 stations are collected and stored by the National Climatic Data Center (NCDC), which were acquired from two different sources: (1) Earth-Info Summary of the Day (EISD) data files (Earth Info, 2011) and (2) data files downloaded by using the Downsizer application (Ward-Garrison and others, 2009). Records from 22 stations were collected and stored by the National Interagency Fire Center's Remote Automated Weather Stations (RAWS). The RAWS data were accessed in January 2008 from http://www.raws.dri.edu/wraws/scaF. $\mathrm{html}$. The 134 climate records were compiled to develop the daily climate inputs required for a simulation period beginning January 1, 1909, and ending December 31, 2012.

\section{Average Monthly Precipitation and Air Temperature}

The SGPWM spatially interpolates daily precipitation and daily maximum and minimum air temperature for each grid cell by using a modified inverse-distance-squared interpolation (Hevesi and others, 2003). The interpolation method requires an estimate of average monthly precipitation and maximum and minimum air temperature at all grid cells and at all climate stations with records used in the interpolation. Following the methods used in Flint and Martin (2012), average monthly precipitation estimated by the Parameter-elevation Regressions on Independent Slopes
Model (PRISM) data (Daly and others, 1994, 2004) was used to define the estimates of average monthly precipitation both for grid cells and climate stations. The monthly PRISM data used in the SGPWM consist of average monthly precipitation maps developed for the area of the United States on an approximate $800-\mathrm{m}$ grid spacing for the 30 -year period from 1971 to 2000 (Daly and others, 1994, 2004). The monthly PRISM estimates incorporate multiple variables in order to account for complex orographic effects on precipitation, such as rain shadows, adiabatic cooling, average storm trajectory, and distance from moisture sources (Daly and others, 1994, 2004).

Following the approach used in Hevesi and others (2003) and Rewis and others (2006), estimates of average monthly maximum and minimum air temperature were calculated by using a linear regression model, where altitude was the dependent variable. The monthly regression models were developed by using daily air-temperature records from 14 stations (table 4) that ranged in altitude from $130 \mathrm{~m}$ (station identifier 46635, Palm Springs) to 2,077 m (station identifier 40742, Big Bear Lake dam). The months of November through February showed the strongest correlation with altitude for monthly maximum air temperature, with R-squared values of 0.95 or greater (table 5). The months of May and June showed the weakest correlation between monthly maximum air temperature and altitude, with $\mathrm{R}$-squared values of 0.77 for May and 0.71 for June. The overall correlation between average monthly minimum air temperature and altitude was weaker than the correlation with maximum air temperature. March and April showed the strongest correlation, with R-squared values of 0.92 for both those months. July and December showed the weakest correlation, with R-squared values of 0.64 for July and 0.68 for December. The weaker correlation for minimum air temperature was likely caused by temperature inversions, frequently during night and early morning, the time when the minimum daily air temperature is usually recorded.

\section{Atmospheric Parameters}

Monthly atmospheric parameters are used by the SGPWM to simulate solar radiation on an hourly basis. Hourly solar radiation is used to simulate daily PET on the basis of an energy balance calculation that also incorporates the daily air temperature inputs. The atmospheric parameters used for the SGPWM are from the USGS (2008) and are the same as values used in the previous INFILv3 application for San Gorgonio Pass (Rewis and others, 2006), as well as the INFILv3 application in the nearby Big Bear Lake and Baldwin Lake watersheds, north of the SGPWM (Flint and Martin, 2012). The monthly atmospheric parameters include (1) the ozone-layer thickness (ozone), in centimeters; (2) precipitable water in the atmosphere (wp), in centimeters; (3) the dimensionless mean atmospheric turbidity (beta); and (4) the dimensionless circumsolar radiation (csr). The monthly ozone parameter varied from 0.27 to $0.33 \mathrm{~cm}$, the wp parameter 
Table 4. Climate stations having records of daily precipitation or records both of daily precipitation and daily maximum and minimum air temperatures, 1909-2012, used in the San Gorgonio Pass watershed model, California.

[Station identifications (IDs) for Earth-Info Summary of the Day (EISD) and Downsizer data sources are National Weather Service-National Climatic Data Center (NWS-NCDC) station identifiers; Station IDs for Remote Automated Weather Service Stations (RAWS) are National Environmental Satellite Service (NESS) station identifiers. Data Sources: EISD: EarthInfo, Inc., 2011, NCDC Summary of the Day, West: Boulder, Colorado, Earth Info, Inc., CD ROM; Downsizer: Ward-Garrison, C., Markstrom, S.L., and Hay, L.E., 2009; Downsizer-A graphical user interface-based application for browsing, acquiring, and formatting time-series data for hydrologic modeling: U.S. Geological Survey Open-File Report 2009-1166, 27 p.; RAWS: Remote Automated Weather Service, http://www.raws.dri.edu/wraws/scaF.html. Gray shading indicates stations used for developing the altitude-air temperature regression model.

Abbreviations: ${ }^{\circ}$, degree; ', minutes; ", seconds]

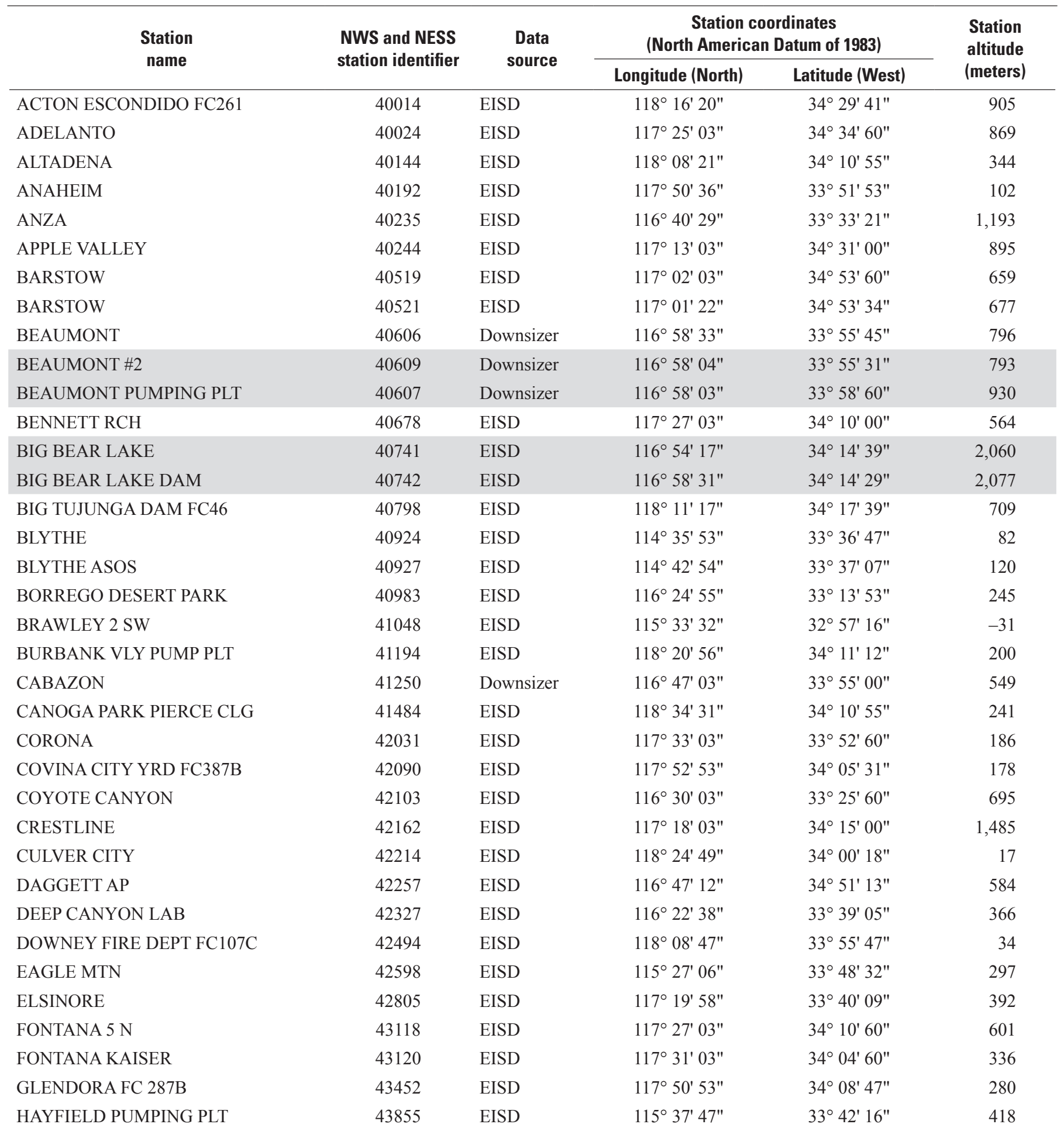


Table 4. Climate stations having records of daily precipitation or records both of daily precipitation and daily maximum and minimum air temperatures, 1909-2012, used in the San Gorgonio Pass watershed model, California.-Continued

[Station identifications (IDs) for Earth-Info Summary of the Day (EISD) and Downsizer data sources are National Weather Service-National Climatic Data Center (NWS-NCDC) station identifiers; Station IDs for Remote Automated Weather Service Stations (RAWS) are National Environmental Satellite Service (NESS) station identifiers. Data Sources: EISD: EarthInfo, Inc., 2011, NCDC Summary of the Day, West: Boulder, Colorado, Earth Info, Inc., CD ROM; Downsizer: Ward-Garrison, C., Markstrom, S.L., and Hay, L.E., 2009; Downsizer-A graphical user interface-based application for browsing, acquiring, and formatting time-series data for hydrologic modeling: U.S. Geological Survey Open-File Report 2009-1166, 27 p.; RAWS: Remote Automated Weather Service, http://www.raws.dri.edu/wraws/scaF.html. Gray shading indicates stations used for developing the altitude-air temperature regression model.

Abbreviations: ${ }^{\circ}$, degree; ', minutes; ", seconds]

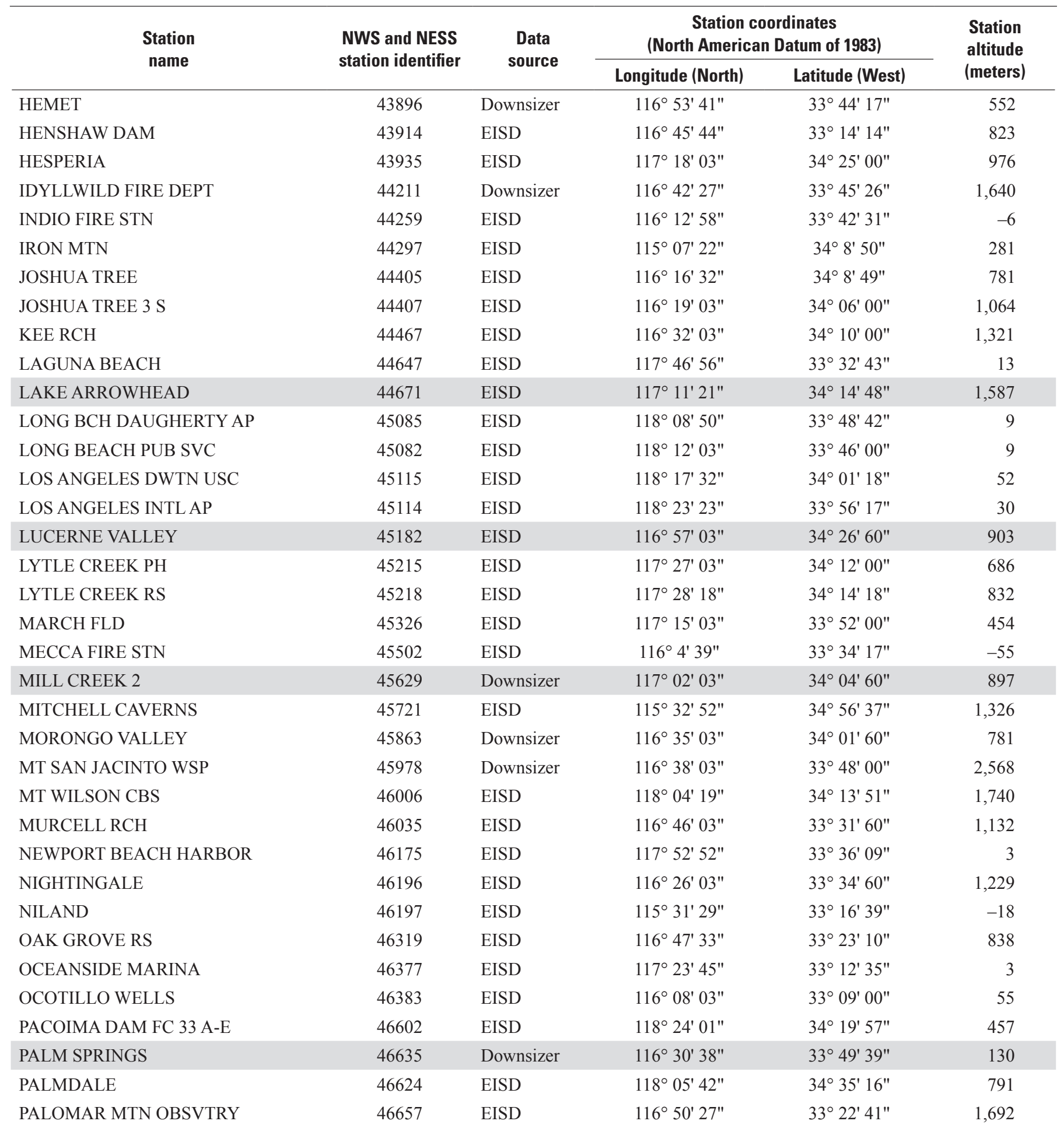


Table 4. Climate stations having records of daily precipitation or records both of daily precipitation and daily maximum and minimum air temperatures, 1909-2012, used in the San Gorgonio Pass watershed model, California._Continued

[Station identifications (IDs) for Earth-Info Summary of the Day (EISD) and Downsizer data sources are National Weather Service-National Climatic Data Center (NWS-NCDC) station identifiers; Station IDs for Remote Automated Weather Service Stations (RAWS) are National Environmental Satellite Service (NESS) station identifiers. Data Sources: EISD: EarthInfo, Inc., 2011, NCDC Summary of the Day, West: Boulder, Colorado, Earth Info, Inc., CD ROM; Downsizer: Ward-Garrison, C., Markstrom, S.L., and Hay, L.E., 2009; Downsizer-A graphical user interface-based application for browsing, acquiring, and formatting time-series data for hydrologic modeling: U.S. Geological Survey Open-File Report 2009-1166, 27 p.; RAWS: Remote Automated Weather Service, http://www.raws.dri.edu/wraws/scaF.html. Gray shading indicates stations used for developing the altitude-air temperature regression model.

Abbreviations: ${ }^{\circ}$, degree; ', minutes; ", seconds]

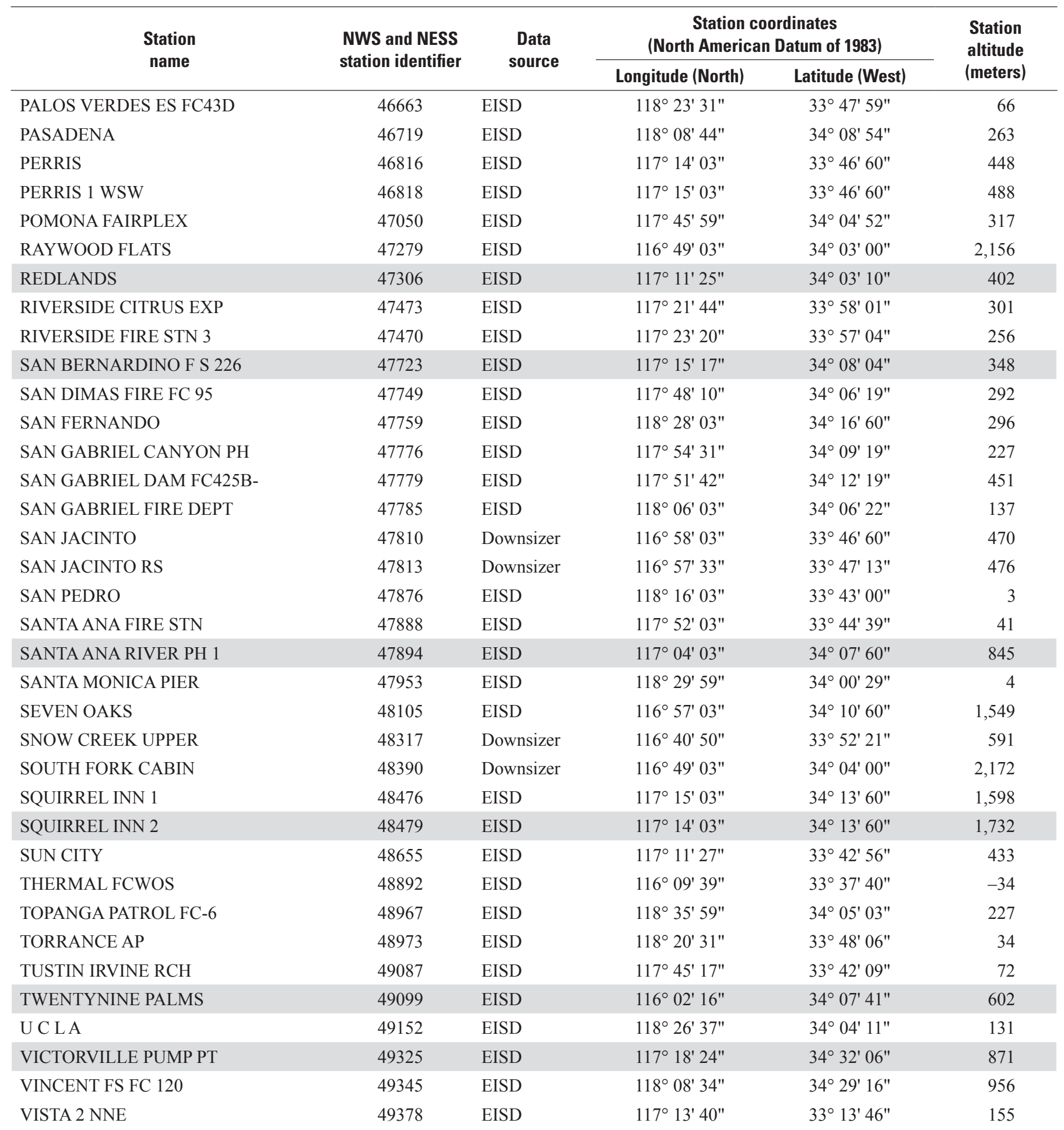


Table 4. Climate stations having records of daily precipitation and/or maximum and minimum air temperature used as input for the San Gorgonio Pass watershed model, California.-Continued

[Station identifications (IDs) for Earth-Info Summary of the Day (EISD) and Downsizer data sources are National Weather Service-National Climatic Data Center (NWS-NCDC) station identifiers; Station IDs for Remote Automated Weather Service Stations (RAWS) are National Environmental Satellite Service (NESS) station identifiers. Data Sources: EISD: EarthInfo, Inc., 2011, NCDC Summary of the Day, West: Boulder, Colorado, Earth Info, Inc., CD ROM; Downsizer: Ward-Garrison, C., Markstrom, S.L., and Hay, L.E., 2009; Downsizer-A graphical user interface-based application for browsing, acquiring, and formatting time-series data for hydrologic modeling: U.S. Geological Survey Open-File Report 2009-1166, 27 p.; RAWS: Remote Automated Weather Service, http://www.raws.dri.edu/wraws/scaF.html. Gray shading indicates stations used for developing the altitude-air temperature regression model.

Abbreviations: `, degree; ', minutes; ", seconds]

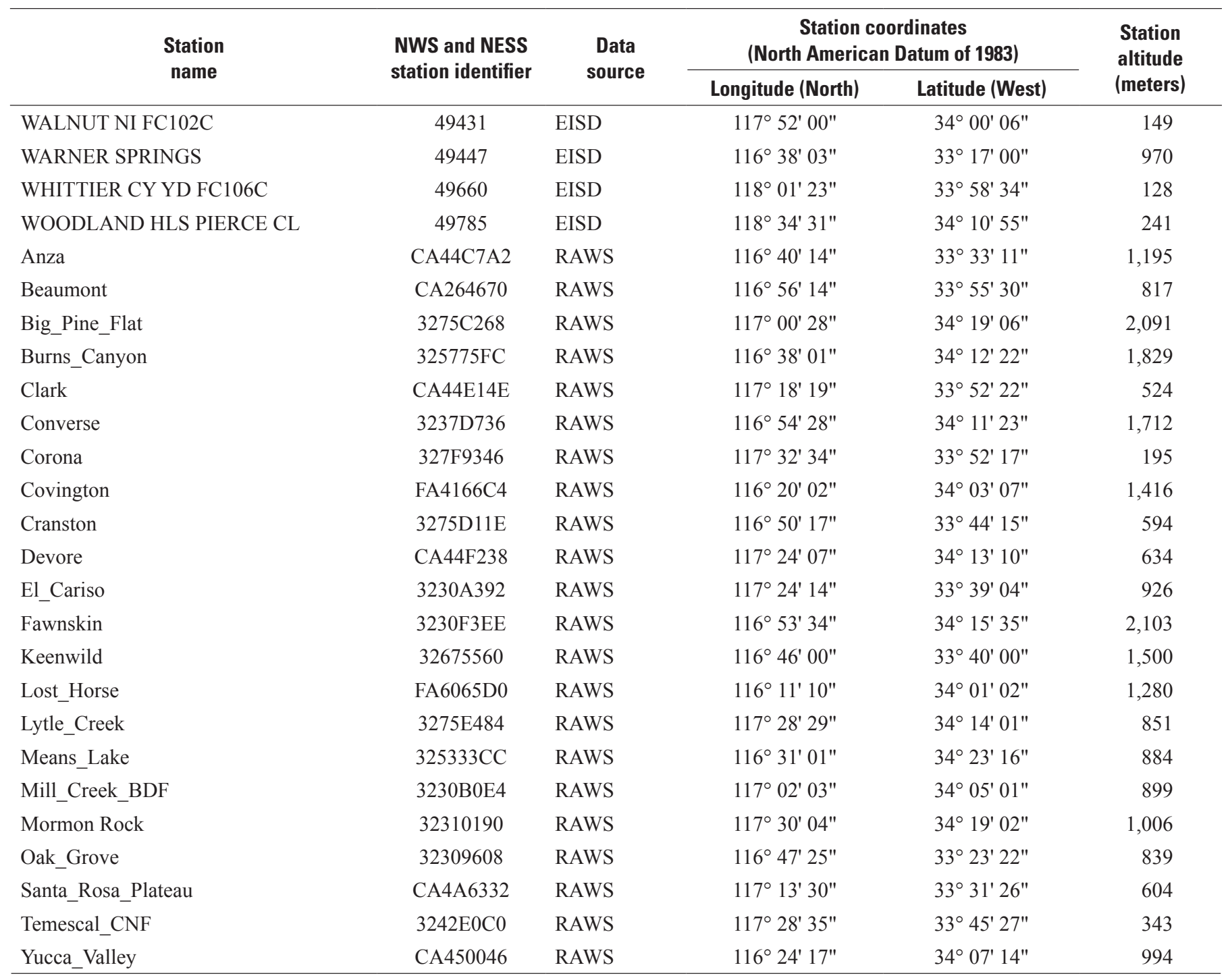


Table 5. Parameters for regression models used to spatially interpolate maximum and minimum daily air temperature for the San Gorgonio Pass watershed model, California.

[Abbreviations: deg. C, temperature in degrees Celsius; m, meters]

\begin{tabular}{|c|c|c|c|c|c|c|}
\hline \multirow{2}{*}{ Month } & \multicolumn{3}{|c|}{$\begin{array}{l}\text { Average monthly maximum air temperature } \\
\text { regression model coefficients and statistics }\end{array}$} & \multicolumn{3}{|c|}{$\begin{array}{l}\text { Average monthly minimum air temperature } \\
\text { regression model coefficients and statistics }\end{array}$} \\
\hline & $\begin{array}{c}\text { Slope } \\
\text { (deg. } \mathrm{C} / \mathrm{m})\end{array}$ & $\begin{array}{l}\text { Intercept } \\
\text { (deg. C) }\end{array}$ & $\begin{array}{c}\text { R-squared } \\
\text { (dimension-less) }\end{array}$ & $\begin{array}{c}\text { Slope } \\
\text { (deg. C/m) }\end{array}$ & $\begin{array}{l}\text { Intercept } \\
\text { (deg. C) }\end{array}$ & $\begin{array}{c}\text { R-squared } \\
\text { (dimension-less) }\end{array}$ \\
\hline Jan & -0.0075 & 21.5 & 0.95 & -0.0064 & 6.9 & 0.75 \\
\hline Feb & -0.0078 & 23.6 & 0.96 & -0.0066 & 8.4 & 0.83 \\
\hline Mar & -0.0082 & 25.8 & 0.93 & -0.0068 & 9.7 & 0.92 \\
\hline Apr & -0.0080 & 29.2 & 0.88 & -0.0067 & 12.0 & 0.92 \\
\hline May & -0.0075 & 32.5 & 0.77 & -0.0064 & 14.7 & 0.88 \\
\hline Jun & -0.0072 & 37.1 & 0.71 & -0.0057 & 17.6 & 0.76 \\
\hline Jul & -0.0076 & 41.4 & 0.81 & -0.0055 & 21.3 & 0.64 \\
\hline Aug & -0.0077 & 41.0 & 0.85 & -0.0057 & 21.3 & 0.70 \\
\hline Sep & -0.0077 & 38.4 & 0.90 & -0.0062 & 19.2 & 0.72 \\
\hline Oct & -0.0076 & 32.8 & 0.93 & -0.0063 & 14.8 & 0.73 \\
\hline Nov & -0.0077 & 26.6 & 0.96 & -0.0061 & 9.9 & 0.70 \\
\hline Dec & -0.0074 & 22.2 & 0.95 & -0.0058 & 6.9 & 0.68 \\
\hline
\end{tabular}

varied from 1.0 to $2.44 \mathrm{~cm}$, the beta parameter varied from 0.075 to 0.09 , and csr parameter varied from 0.57 to 0.9 (table 6). A more complete description of these parameters is provided in Rewis and others (2006), Hevesi and others (2003), and U.S. Gelogical Survey (2008).

\section{Model Coefficients}

Model coefficients include parameters used to model snowmelt and sublimation, to define stream-channel characteristics, and to define precipitation intensity by using specified winter and summer storm durations. For the SGPWM, model coefficients were based on previous applications of the INFILv3 code in the Southern California region (Rewis and others, 2006; Flint and Martin, 2012). Model coefficients for simulating snowmelt and sublimation were from Hevesi and others (2003) for the Death Valley region and were assumed to be applicable for the San Gorgonio Pass region because of the similar climate characteristics.

Model coefficients used to represent stream-channel characteristics included the minimum number of upstream cells used to define the main-stream channels and the saturated hydraulic-conductivity multiplier for soils in the main stream channels. The minimum number of upstream cells was set to 100 (approximately 9 hectares), and the saturated hydraulicconductivity multiplier was set to 10 . This configuration assumed coarser soils in active channels that had upstream areas of 9 hectares or greater as well as a 10-fold increase in the saturated hydraulic conductivity of the channel bed relative to the surrounding inter-channel areas.
Table 6. Monthly values of atmospheric parameters used to simulate solar radiation and potential evapotranspiration with the San Gorgonio Pass watershed model, California.

\begin{tabular}{lcccc}
\hline Month & \multicolumn{4}{c}{ Monthly atmospheric parameter values $^{\mathbf{1}}$} \\
\cline { 2 - 5 } & $\begin{array}{c}\text { Ozone }^{2} \\
\text { (centimeters) }\end{array}$ & $\begin{array}{c}\text { WP }^{3} \\
\text { (centimeters) }\end{array}$ & $\begin{array}{c}\text { Beta }^{4} \\
\text { (dimensionless) }\end{array}$ & $\begin{array}{c}\text { CSR }^{5} \\
\text { (dimensionless) }\end{array}$ \\
\hline Jan & 0.29 & 1.00 & 0.075 & 0.85 \\
Feb & 0.31 & 1.00 & 0.075 & 0.85 \\
Mar & 0.32 & 1.05 & 0.075 & 0.85 \\
Apr & 0.33 & 1.10 & 0.085 & 0.85 \\
May & 0.33 & 1.50 & 0.085 & 0.74 \\
Jun & 0.32 & 1.80 & 0.090 & 0.74 \\
Jul & 0.30 & 2.20 & 0.090 & 0.57 \\
Aug & 0.29 & 2.44 & 0.084 & 0.57 \\
Sep & 0.28 & 2.00 & 0.077 & 0.66 \\
Oct & 0.27 & 1.40 & 0.075 & 0.74 \\
Nov & 0.27 & 1.05 & 0.075 & 0.90 \\
Dec & 0.28 & 0.95 & 0.075 & 0.90 \\
\hline
\end{tabular}

'Parameter values from U.S. Geological Survey, 2008, Documentation of computer program INFIL3.0-A distributed-parameter watershed model to estimate net infiltration below the root zone: U.S. Geological Survey Scientific Investigations Report 2008-5006, 98 p.

${ }^{2}$ Ozone: ozone-layer thickness.

${ }^{3} \mathrm{WP}$ : precipitable water in the atmosphere.

${ }^{4}$ Beta: mean atmospheric turbidity.

${ }^{5} \mathrm{CSR}$ : circumsolar radiation. 


\section{Modeled Climate, Snowfall, and Potential Evapotranspiration (PET)}

The spatial and temporal distributions of the interpolated climate inputs (precipitation and air temperature), as well as the spatial and temporal distributions of simulated snowfall and PET, were analyzed as part of model development. Snowfall and PET are included as climate components in the SGPWM simulated water budget because snowfall is dependent only on spatially interpolated precipitation and air temperature and PET is dependent only on the interpolated climate inputs (precipitation and air temperature), latitude, topographic parameters (slope, aspect, and blocking ridges), and the atmospheric parameters (U.S. Geological Survey, 2008). Clear sky PET is simulated by the INFILv3 code using maximum and minimum daily air-temperature input and an energy-balance approach that includes hourly simulated solar radiation (Flint and Childs, 1987; Flint and Childs, 1991; U.S. Geological Survey, 2008). To account for cloud cover, PET is reduced on the basis of the amount of precipitation. Precipitation, air temperature, snowfall, and PET were analyzed by using the mapped spatial distribution of the long-term 100-year averages for the target simulation period (1913-2012), the annual (water year) time series, and the 100-year monthly averages.

\section{Precipitation}

Spatially distributed precipitation, averaged for water years 1913-2012, ranged from a minimum of about 230 millimeters per year $(\mathrm{mm} / \mathrm{yr})$, on the valley floor at the Indio subbasin along the eastern boundary, to a maximum of about $970 \mathrm{~mm} / \mathrm{yr}$, at the summit of Little San Gorgonio Peak (fig. 11). Average precipitation in the western and central parts of the SGPGSA was 421 and $480 \mathrm{~mm} / \mathrm{yr}$, respectively. Basinwide average precipitation for the SGPWM was $496 \mathrm{~mm} / \mathrm{yr}$. In general, the distribution of precipitation was similar to the average annual PRISM map (Daly and others, 2004). Unlike PRISM, however, the precipitation - interpolated by the modified inverse distance squared method-was more closely matched to the daily records of the climate stations in and around the SGPWM because the daily data are preserved in the spatial interpolation algorithm (Hevesi and others, 2003; Flint and Martin, 2012).

\section{Air Temperature and Snowfall}

The spatially distributed average daily air temperature, calculated as the average of the maximum and minimum daily air temperature for water years 1913-2012 and interpolated by the SGPWM, varied from a maximum of $20^{\circ} \mathrm{C}$ in the Indio subbasin to a minimum of about $0^{\circ} \mathrm{C}$ for the summit area of Little San Gorgonio Peak (fig. 12). The 100-year average air temperature in the central part of the SGPGSA varied from about 16 to $18{ }^{\circ} \mathrm{C}$. The basin-wide average air temperature for the SGPWM was $14.5^{\circ} \mathrm{C}$. In contrast to the spatial distribution of precipitation, the spatial distribution of interpolated air temperature is largely determined by the air temperature and altitude regression model and, therefore, closely follows the topography.

The spatially distributed average snowfall for water years 1913-2012, calculated by the SGPWM using the spatially interpolated air temperature and precipitation inputs, ranged from a minimum of zero throughout the valley floor to a maximum of about $880 \mathrm{~mm}$ for the summit of Little San Gorgonio Peak (fig. 12). Snowfall amounts of about $51 \mathrm{~mm} / \mathrm{yr}$ and more, or amounts greater than the basin-wide average snowfall of $50 \mathrm{~mm} / \mathrm{yr}$ for the SGPWM, only fell in the higher-altitudes of Little San Gorgonio Peak and San Jacinto Peak, where the average air temperature was about $12{ }^{\circ} \mathrm{C}$ or less. The 100 -year average snowfall in the central part of the SGPGSA was negligible (less than $2 \mathrm{~mm} / \mathrm{yr}$ ).

\section{Potential Evapotranspiration (PET)}

Average annual PET for water years 1913-2012 ranged from a maximum of 2,080 mm/yr for a cell on the southfacing slope of the San Gorgonio River valley floor, close to the eastern boundary of the model domain, to a minimum of $485 \mathrm{~mm} / \mathrm{yr}$ for a cell in an upper ravine on the north-facing slope of Mount Jan Jacinto (fig. 13). The basin-wide average simulated PET for the SGPWM was about 1,620 mm/yr, and was in good agreement with the average value of $1,590 \mathrm{~mm} / \mathrm{yr}$ for CIMIS ET zone 16 that included most of the SGPWM. Simulated PET for most of the north-facing slope of San Jacinto Peak was less than $1,500 \mathrm{~mm} / \mathrm{yr}$ because of shading effects from the rugged topography. In contrast, simulated PET for most of the south-facing slope of Little San Gorgonio Peak was greater than $1,500 \mathrm{~mm} / \mathrm{yr}$, with the exception of the highest altitudes and north-facing slopes of smaller canyons and ravines in the mountain block.

\section{Annual Variability in Climate}

The temporal variability in the basin-wide climate components of the SGPWM was evaluated by using the time series of spatially averaged annual (water year) precipitation, air temperature, snowfall, and PET for water years 1913-2012. The spatially averaged annual values were calculated by summing the annual results for all 30,595 model cells and dividing the sum by the number of model cells. Annual precipitation during the century showed high year-to-year variability relative to the 100 -year average precipitation of $496 \mathrm{~mm} / \mathrm{yr}$, with a maximum annual precipitation of $1,100 \mathrm{~mm}$ for water year 1993 and a minimum annual precipitation of $98 \mathrm{~mm}$ for water year 2007 (fig. 14A). Water years with relatively high precipitation, $800 \mathrm{~mm}$ and greater, were often followed by water years with relatively low precipitation, $400 \mathrm{~mm}$ and less. The annual results indicated a pattern of increasing year-to-year variability, with the 4 wettest and the 3 driest years all after water year 1960. The 5 driest years $(1959,1961$, 


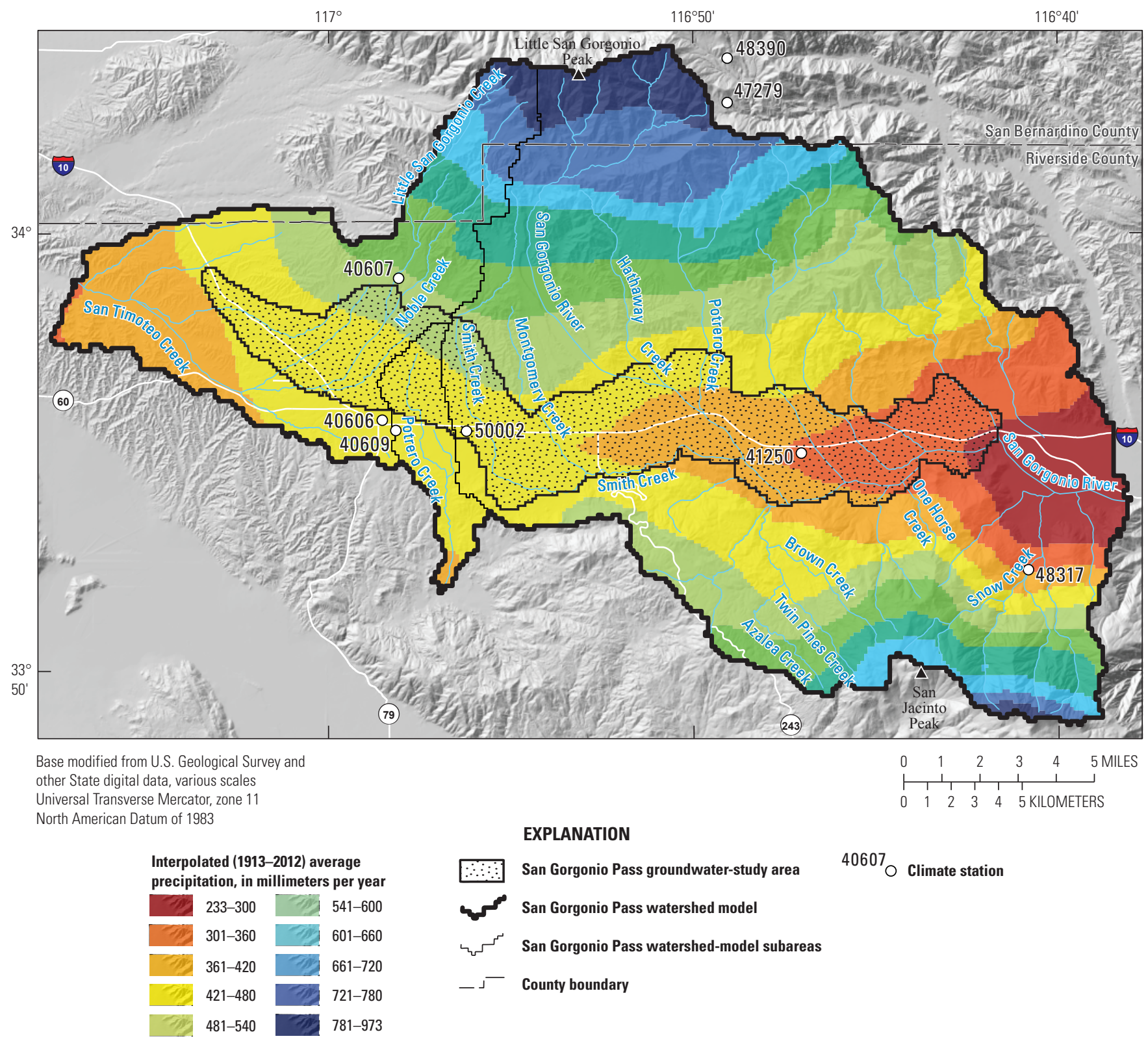

Figure 11. Spatially distributed average annual precipitation estimated for water years 1913-2012 by using the San Gorgonio Pass watershed model, California. 


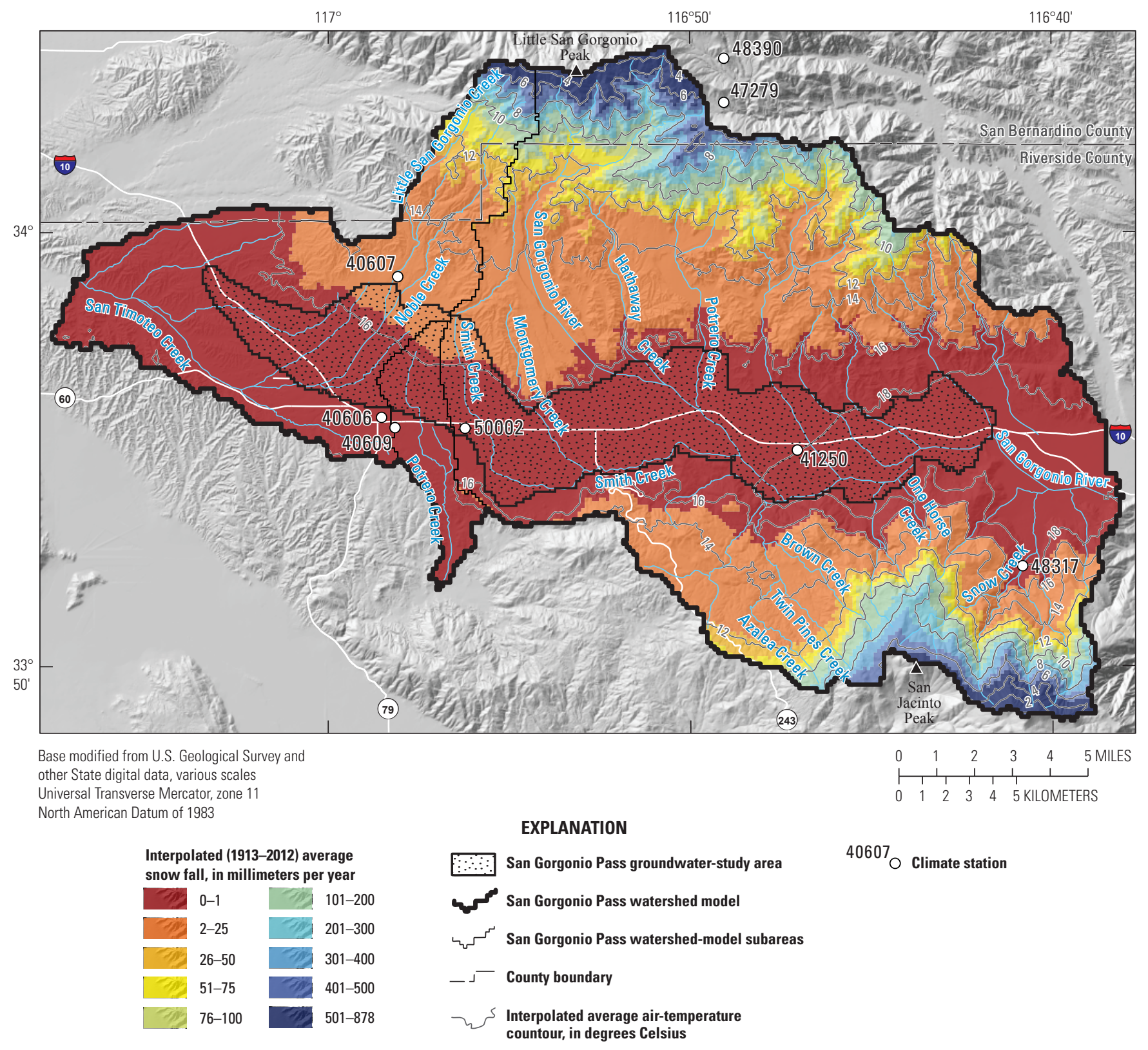

Figure 12. Spatially distributed average air temperature and snowfall estimated for water years 1913-2012 using the San Gorgonio Pass watershed model, California. 


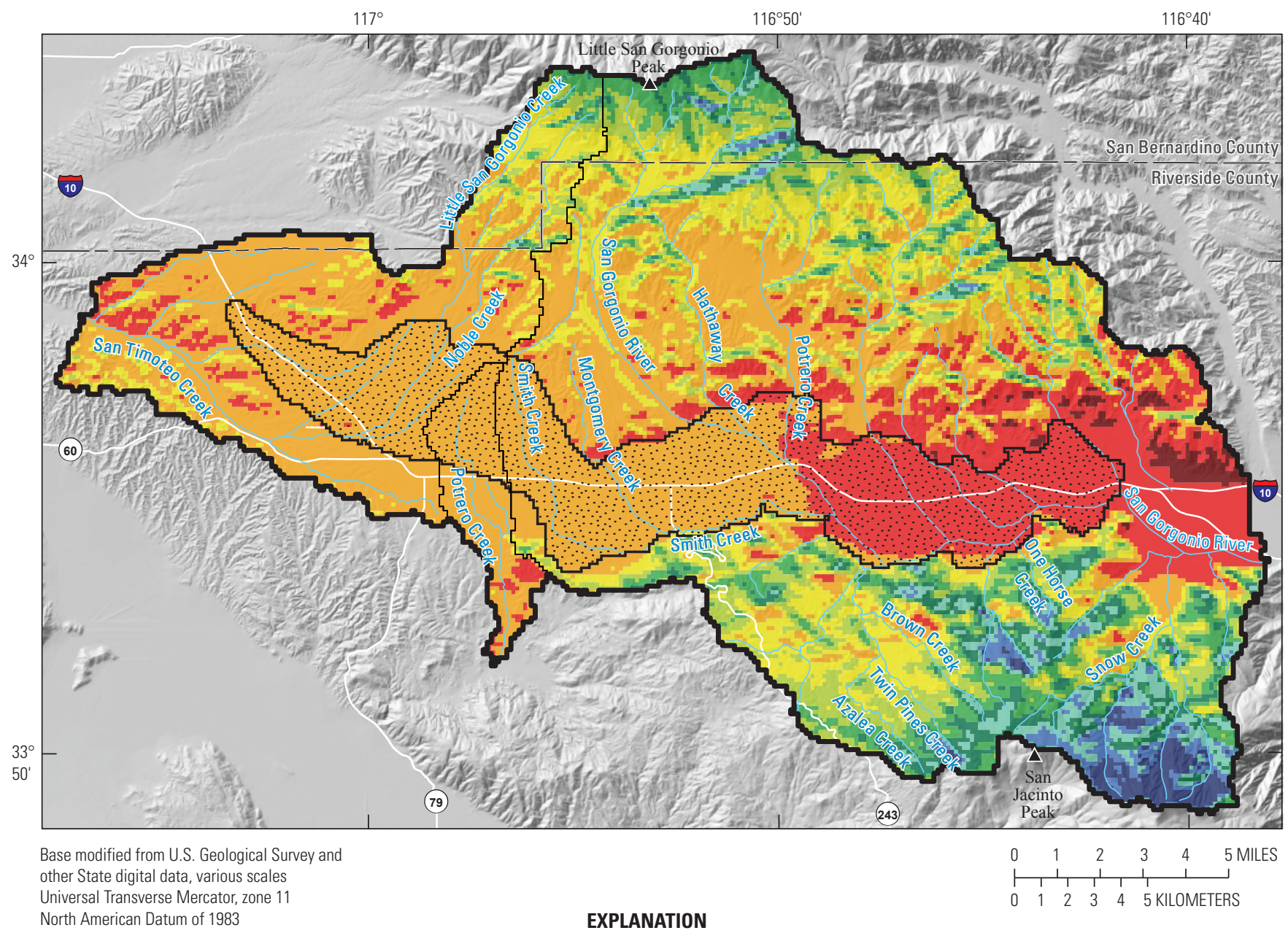

\begin{tabular}{|c|c|c|c|c|}
\hline \multicolumn{3}{|c|}{$\begin{array}{l}\text { Simulated (1913-2012) average potential } \\
\text { evapotranspiration, in millimeters per year }\end{array}$} & \multirow{2}{*}{\multicolumn{2}{|c|}{ San Gorgonio Pass groundwater-study area }} \\
\hline & $485-820$ & $1,381-1,520$ & & \\
\hline & $821-960$ & $1,521-1,660$ & & onio Pass watershed-model subareas \\
\hline & $961-1,100$ & $1,661-1,800$ & & \\
\hline & $1,101-1,240$ & $1,801-1,940$ & & County boundary \\
\hline (3) & $1,241-1,380$ & $1,941-2,080$ & & \\
\hline
\end{tabular}

Figure 13. Spatially distributed average annual potential evapotranspiration simulated for water years 1913-2012 using the San Gorgonio Pass watershed model, California. 

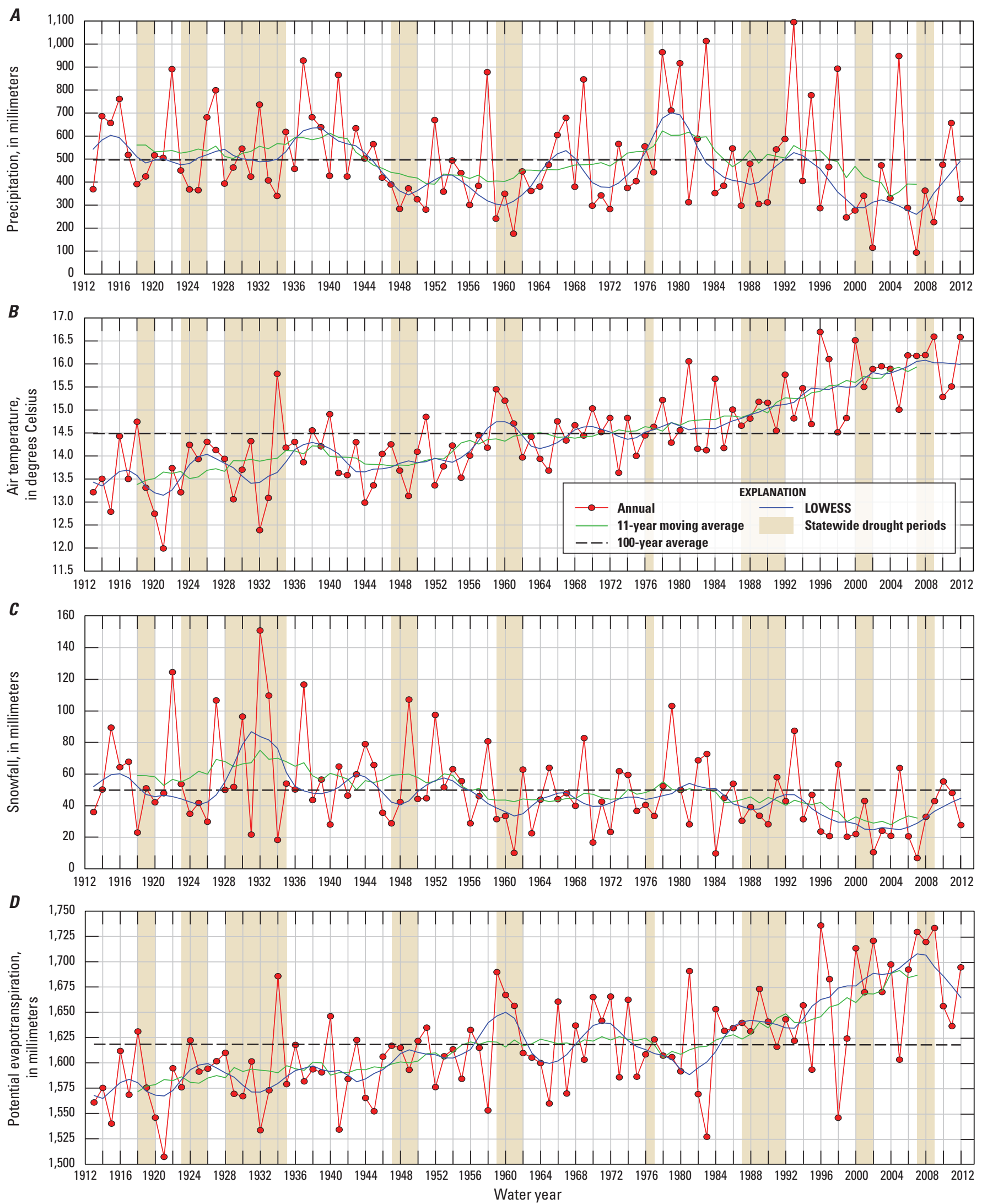

Figure 14. Annual basin-wide averages for water years 1913-2012 using the San Gorgonio Pass watershed model, California, for $A$, estimated precipitation; $B$, estimated air temperature; $C$, simulated snowfall; and $D$, simulated potential evapotranspiration (PET). 
2002, 2007, and 2009) were all during state-wide drought periods (fig. 14) identified by the California Department of Water Resources (2012). Average precipitation for the 37 drought years in the 100-year period was $396 \mathrm{~mm} / \mathrm{yr}$, or about 80 percent of the 100 -year period average of $496 \mathrm{~mm} / \mathrm{yr}$.

To help identify multi-year trends and cycles in the annual time series, two smoothing functions were applied: (1) the 11-year moving mean and (2) the locally weightedscatterplot-smoothing (LOWESS) method (Maidment, 2002). The California Department of Water Resources (DWR) uses the 11-year moving average in the analysis of annual statewide precipitation because precipitation and other climatic variables have been associated with 11-year periods (California Department of Water Resources, 2012). The locally weighted-scatterplot-smoothing (LOWESS) method was applied because it spans the entire domain and is not sensitive to outliers as is the moving average (Maidment, 2002). The smoothed time series of annual precipitation based on the 11 -year moving average indicated relatively wetter than average periods for water years 1915-44, 1973-85, and 1990-97, whereas extended dry periods were indicated for water years 1945-72, and 1998-2008. The LOWESS curve indicated wetter than average periods for water years 1912-44, 1966$68,1976-82$, and 1992-94, and drier than average periods for water years 1945-65, 1983-91, and 1996-2011.

The annual and smoothed time series indicated dry periods that were in good agreement with the DWR state-wide drought periods of 1947-50, 1959-62, 1987-92, 2000-02, and 2007-09. The results showed poor agreement to the state-wide drought periods of 1928-35 and 1976-77, however, and only partial agreement to the drought periods of 1918-20, 1923-26, and 1987-92. In addition, many of the drier years that had less than $300 \mathrm{~mm}$ precipitation (for example, water years 1951, 1970, 1972, 1996, 1999, and 2000) were not during the DWR drought periods. The comparison with the state-wide drought periods indicated that the SGPWM climate might not always follow state-wide climate conditions, and local-scale climate variability is likely to be important. Average precipitation for the 37 DWR drought years was $396 \mathrm{~mm} / \mathrm{yr}$, and annual precipitation was usually less than the long-term average of $496 \mathrm{~mm} / \mathrm{yr}$ for most years identified as drought years. Exceptions included water years 1926, 1932, and 1935; all these had annual precipitation greater than $600 \mathrm{~mm}$.

The annual time series for average air temperature indicated a well-defined trend of increasing air temperature from water year 1913 to 2012 (fig. 14B). Water years with average air temperature less than $13{ }^{\circ} \mathrm{C}$ were all prior to water year 1933 , and water years with average air temperature greater than $16.5^{\circ} \mathrm{C}$ were all after water year 1995 . Both the 11 -year centered moving-average air temperature and the LOWESS average air temperature were about $13.5^{\circ} \mathrm{C}$ during the beginning of the period and both increased to almost $16^{\circ} \mathrm{C}$ by the end of the period.

Variability in estimated annual snowfall indicated the combined effects of estimated precipitation and air temperature (fig. 14C). Similar to precipitation, annual snowfall for the SGPWM showed a high degree of year-to-year variation; however, snowfall also was sensitive to the annual variations in air temperature and to the intra-annual timing of precipitation in a given water year. For example, water year 1932 had the highest basin-wide average snowfall of $150 \mathrm{~mm}$. The high snowfall resulted from above average annual precipitation, with a basin-wide average precipitation of about $725 \mathrm{~mm}$ for water year 1932, at the same time the average air temperature was the second coldest $\left(12.4^{\circ} \mathrm{C}\right)$ in the 100 -year period. Following the trend of increasing air temperature, a slight trend of decreasing snowfall was indicated by both the 11-year moving mean and the LOWESS curve for water year 1933-2012 (fig. 14C). With the exception of water year 1979, all years that had high annual snowfall amounts of $100 \mathrm{~mm}$ or greater were prior to water year 1950, whereas most of the years that had low annual snowfall amounts of $20 \mathrm{~mm}$ and less were after water year 1950.

The annual variability in basin-wide average PET (fig. 14D) was closely correlated to the annual variability in basin-wide average air temperature; however, there was also some dependency on the variability in annual precipitation. The SGPWM accounts for the effects of cloud cover on PET by using an empirical function that reduces PET as a function of the daily precipitation (U.S. Geological Survey, 2008). Water year 1921 had the lowest PET at about 1,510 mm and also was the water year with the lowest average air temperature at $12{ }^{\circ} \mathrm{C}$. Water years 1983 and 1998 also had the second and fifth lowest annual PET values at about $1,527 \mathrm{~mm}$ and 1,546 $\mathrm{mm}$, respectively, because annual temperatures were near average and annual precipitation was relatively high, second and fourth highest and in water years 1983 and 1998, respectively. Overall, annual PET, the 11-year moving average, and LOWESS showed a trend toward increasing PET. This PET trend was caused primarily by higher air temperatures in the later part of the simulation period.

\section{Average Monthly Variability in Climate}

The basin-wide monthly averages, maximums, and minimums for spatially interpolated precipitation, air temperature, snowfall, and PET indicated the average seasonal variability in the climate components for the SGPWM (fig. 15). The monthly averages were calculated for each month by summing the monthly totals for water years 1913 to 2012 for all 30,595 model cells and dividing by the number of model cells and the number of months in the 100-year period $(1,200)$. On average, monthly precipitation and snowfall were greatest during December through March and least during May through September (figs. 15A, C). All months included a minimum monthly precipitation and snowfall of zero, and maximum monthly values more than three times greater than the mean, indicating a high degree of temporal variability. The seasonal variation in average monthly air temperature and PET was also pronounced; however, in contrast to precipitation and snowfall, air temperature and PET were greatest during summer months and least during winter months. In addition, 

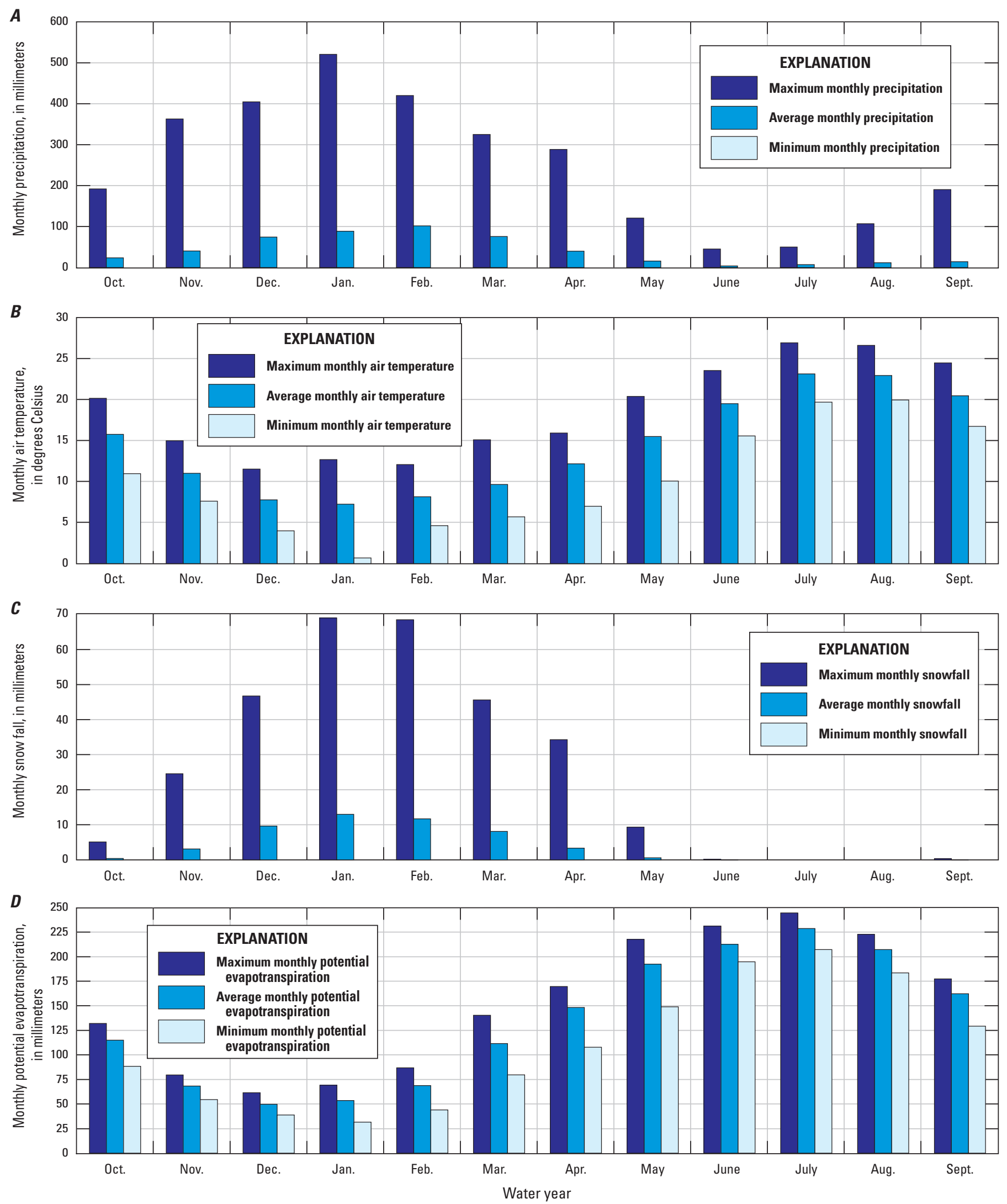

Figure 15. Basin-wide averages for water years 1913-2012, using the San Gorgonio Pass watershed model, California, for $A$, estimated monthly precipitation; $B$, estimated air temperature; $C$, simulated snowfall; and $D$, simulated potential evapotranspiration. 
the temporal variability in air temperature and PET for a given month was much lower compared to precipitation and snowfall, as indicated by the smaller relative difference between maximum and minimum monthly values (figs. $15 B, D$ ). For the winter months of December through February, precipitation exceeded PET, increasing the potential for groundwater recharge and runoff for these months.

\section{Model Calibration}

Precipitation-runoff models typically are calibrated and tested by comparing simulated streamflow to available records of measured streamflow, preferably using continuous records that span multi-year periods (Hevesi and others, 2003; Rewis and others, 2006; Markstrom and others, 2008; Jeton and Maurer, 2011). In the model-calibration procedure, parameters affecting streamflow that have a high degree of uncertainty are adjusted iteratively until an acceptable fit between simulated and measured streamflow is achieved. The model developed for this study is an expanded and updated version of the calibrated INFILv3 model from Rewis and others (2006). Calibration was limited for this study to adjusting parameters that only control seepage flow because this process was not simulated by the Rewis model. Parameters affecting seepage flow include the hydraulic conductivities for layers 6 and 7 . In addition, calibration did not include the use of automated parameter estimation algorithms, such as the parameterestimation (PEST) application (Doherty, 2008).

The model was calibrated both qualitatively and quantitatively by comparing simulated and measured streamflow at five USGS stream streamgages (Little San Gorgonio Creek, LSGC; San Timoteo Creek near Redlands, STCR; Snow Creek near White Water, SCWW; Chino Canyon Creek below Tramway, CCCT; and Tahquitz Creek near Palm Springs, TCNP) in and next to the SGPWM (fig. 16; table 7). The five streamgages were selected on the basis of (1) the location of drainage area either in or directly next to the SGPWM and (2) a length of record of 25 years or longer. The goodness-of-fit between simulated and measured streamflow was evaluated by using monthly mean discharge, annual (water year) mean discharge, and average monthly mean discharge. The qualitative analysis also included scatterplots of simulated against measured monthly and annual streamflow to evaluate residuals. The comparison of average monthly streamflow was done to evaluate model performance in terms of representing the seasonal distribution of streamflow.

A quantitative analysis of the goodness-of-fit between simulated and measured streamflow was done by using the percent-average estimation error (PAEE) and the NashSutcliffe model efficiency (NSME) statistics (Nash and Sutcliffe, 1970; Woolfenden and Nishikawa, 2014). The PAEE statistic provides a measure of model bias, where a value of 0.0 percent indicates a purely unbiased model fit. Values of PAEE in the range of plus or minus 10 percent are usually considered to indicated a good fit. For this study, values of plus or minus 30 percent were considered satisfactory because streamflow in the study area tends to be a small component of the water balance relative to precipitation and evapotranspiration. The NSME statistic is a standardized mean squared error statistic that is often used to compare results between different models (Nash and Sutcliffe, 1970; Markstrom and others, 2008). An NSME value greater than 0.0 indicates the model provides a better match to the measured values than the mean of the measured values. The closer the NSME is to 1.0, the better the match between simulated and measured values. The sample mean provides an NSME of 0.0 , and negative NSME values indicate a model that does not perform as well as the sample mean in terms of predicting observed values. For this study, an NSME of 0.3 was considered a satisfactory fit.

\section{Streamflow Records}

Daily streamflow records for the five streamgages were obtained from NWIS (http://waterdata.usgs.gov/ca/nwis/dv). Monthly and annual mean discharge for each streamgage was calculated by using the daily records; in some cases, months that had missing daily records were still used for the comparison of simulated against measured monthly and annual streamflow. Lengths of record for the streamgages ranged from a maximum of 63 years for streamgage Tahquitz Creek near Palm Springs (TCNP) to a minimum of 25 years for streamgage Chino Canyon Creek below Tramway (CCCT). The drainage areas upstream of the streamgages range from 5 square-km for streamgage Little San Gorgonio Creek (LSGC) to 306 square-km for streamgage San Timoteo Creek near Redlands (STCR). Only two of the five streamgages, LSGC and Snow Creek near White Water (SCWW), have drainage areas completely within the SGPWM. About half of the STCR drainage area is outside of the SGPWM. The STCR streamgage was included in model calibration because of its proximity to the SGPWM and because it includes the entire area of the STC subdomain. Two of the streamgages, TCNP and CCCT, have drainage areas completely outside of the SGPWM, but were included because of their proximity to the SGPWM.

\section{Calibration Results}

\section{Little San Gorgonio Creek (LSGC)}

Comparison of simulated to measured streamflow at streamgage LSGC was done by using results from this model and the Rewis model. The LSGC streamgage was the only streamgage where a comparison of both models could be done.

Comparison of simulated and measured monthly streamflow at streamgage LSGC indicated that the fit-to-measured streamflow was very similar, but not identical, to the Rewis model (fig. 17). The reason for the differences in results was 


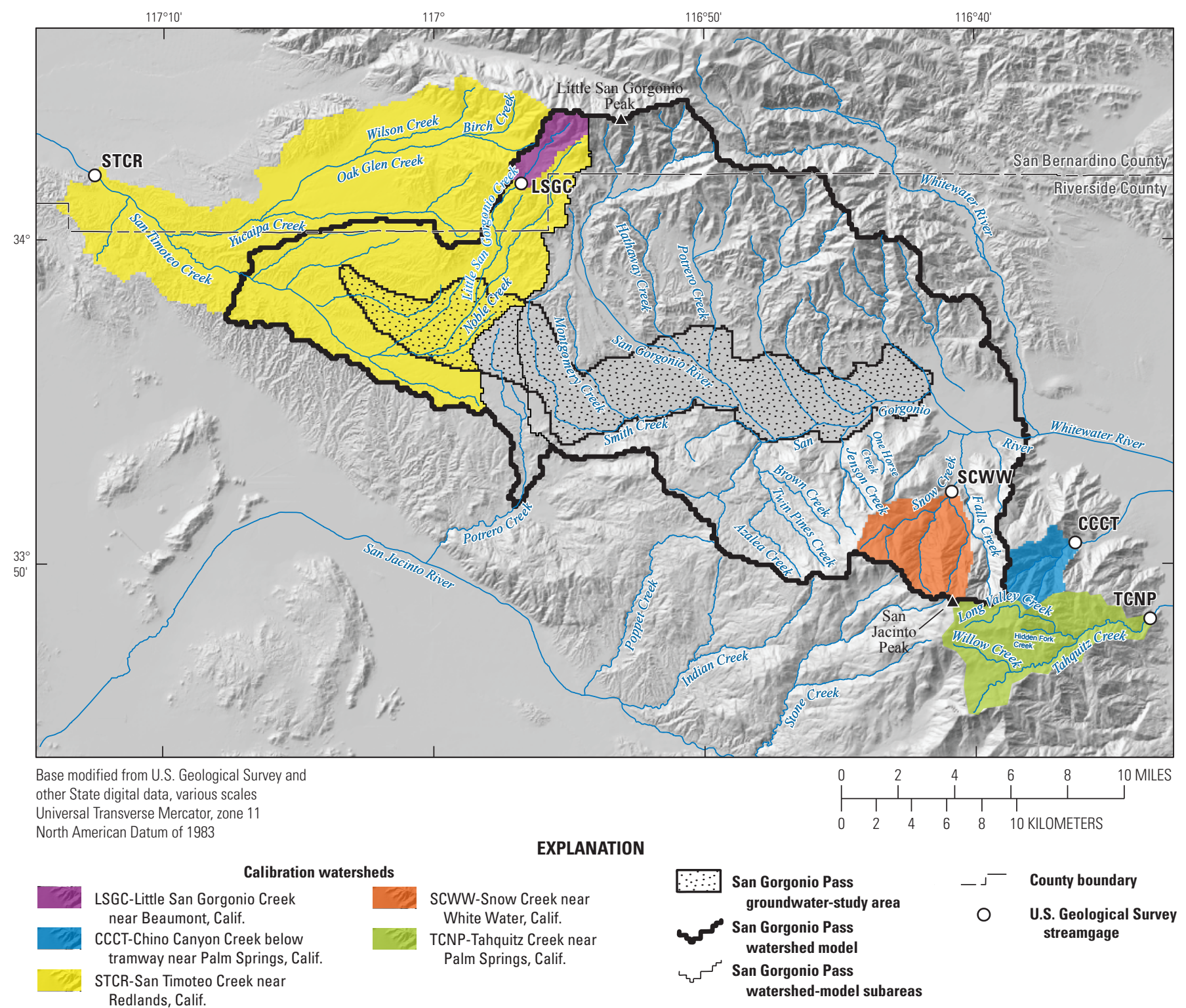

Figure 16. Location of five streamgages used for model calibration, San Gorgonio Pass watershed model, California.

Table 7. Streamflow records used for model testing, San Gorgonio Pass watershed model, California.

[Abbreviations: mm/dd/yyyy, month/day/year; NAD29, North American Datum of 1929; SGPWM, San Gorgonio Pass Watershed Model; sq-km, square kilometers; USGS, U.S. Geological Survey; ` , degree; ', minutes; ", seconds]

\begin{tabular}{|c|c|c|c|c|c|c|c|c|}
\hline \multirow{2}{*}{$\begin{array}{l}\text { SGPWM } \\
\text { station } \\
\text { code }\end{array}$} & \multirow{2}{*}{$\begin{array}{c}\text { USGS } \\
\text { station } \\
\text { identifier }\end{array}$} & \multirow{2}{*}{$\begin{array}{c}\text { USGS } \\
\text { station } \\
\text { name }\end{array}$} & \multicolumn{2}{|c|}{$\begin{array}{l}\text { Station coordinates } \\
\text { (NAD29) }\end{array}$} & \multirow{2}{*}{$\begin{array}{c}\text { Drainage } \\
\text { area } \\
\text { (sq-km) }\end{array}$} & \multicolumn{3}{|c|}{ Records use in this study } \\
\hline & & & $\begin{array}{l}\text { Latitude } \\
\text { (North) }\end{array}$ & $\begin{array}{l}\text { Longitude } \\
\text { (West) }\end{array}$ & & $\begin{array}{l}\text { Begin date } \\
\text { (mm/dd/yyyy) }\end{array}$ & $\begin{array}{c}\text { End date } \\
\text { (mm/dd/yyyy) }\end{array}$ & $\begin{array}{l}\text { Years of } \\
\text { record }\end{array}$ \\
\hline SCWW & 10256500 & Snow Creek near White Water Calif. & $33^{\circ} 52^{\prime} 14^{\prime \prime}$ & $116^{\circ} 40^{\prime} 49^{\prime \prime}$ & 28 & 07/21/1921 & 07/17/2011 & 52 \\
\hline CCCT & 10257720 & $\begin{array}{l}\text { Chino Canyon Creek below tramway } \\
\text { near Palm Springs Calif. }\end{array}$ & $33^{\circ} 50^{\prime} 39^{\prime \prime}$ & $116^{\circ} 36^{\prime} 16^{\prime \prime}$ & 12 & $10 / 01 / 1986$ & $12 / 31 / 2012$ & 25 \\
\hline TCNP & 10258000 & Tahquitz Creek near Palm Spring Calif. & $33^{\circ} 48^{\prime} 18^{\prime \prime}$ & $116^{\circ} 33^{\prime} 30^{\prime \prime}$ & 44 & $10 / 01 / 1947$ & $11 / 04 / 2012$ & 63 \\
\hline LSGC & 11056500 & $\begin{array}{l}\text { Little San Gorgonio Creek near } \\
\text { Beaumont Calif. }\end{array}$ & $34^{\circ} 01^{\prime} 59^{\prime \prime}$ & $116^{\circ} 56^{\prime} 43^{\prime \prime}$ & 5 & $10 / 01 / 1948$ & 09/30/1985 & 37 \\
\hline STCR & 11057000 & San Timoteo Creek near Redland Calif. & $34^{\circ} 01^{\prime} 59^{\prime \prime}$ & $117^{\circ} 12^{\prime} 29^{\prime \prime}$ & 306 & $10 / 01 / 1926$ & 04/07/1979 & 48 \\
\hline
\end{tabular}



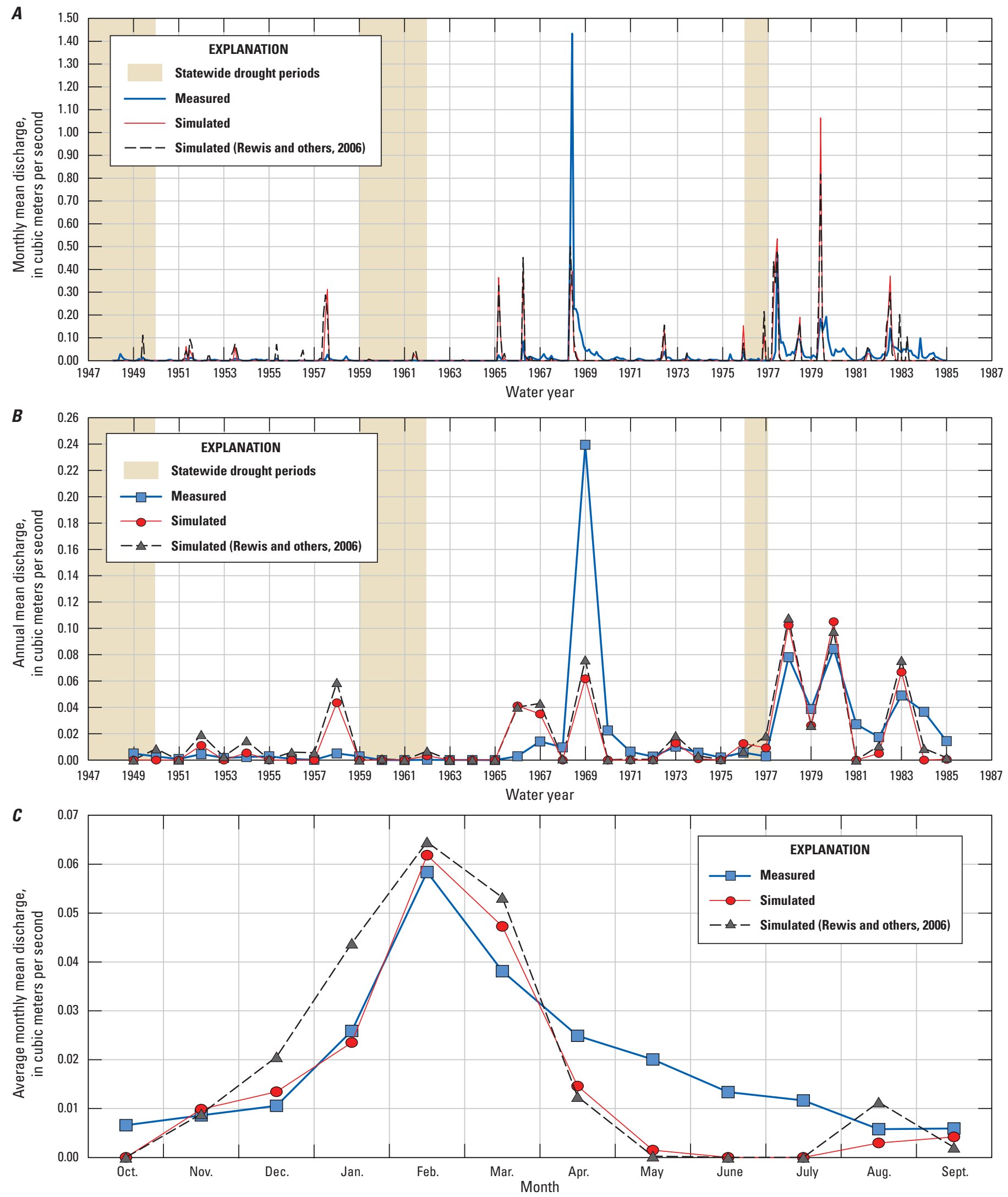

Figure 17. Comparison of simulated and measured streamflow at the Little San Gorgonio Creek (LSGC) streamgage using the San Gorgonio Pass watershed model, California: $A$, monthly mean discharge; $B$, water year mean discharge; $C$, average monthly mean discharge; $D$, scatterplot of simulated to measured monthly mean discharge; and $E$, scatterplot of simulated to measured water year mean discharge. 

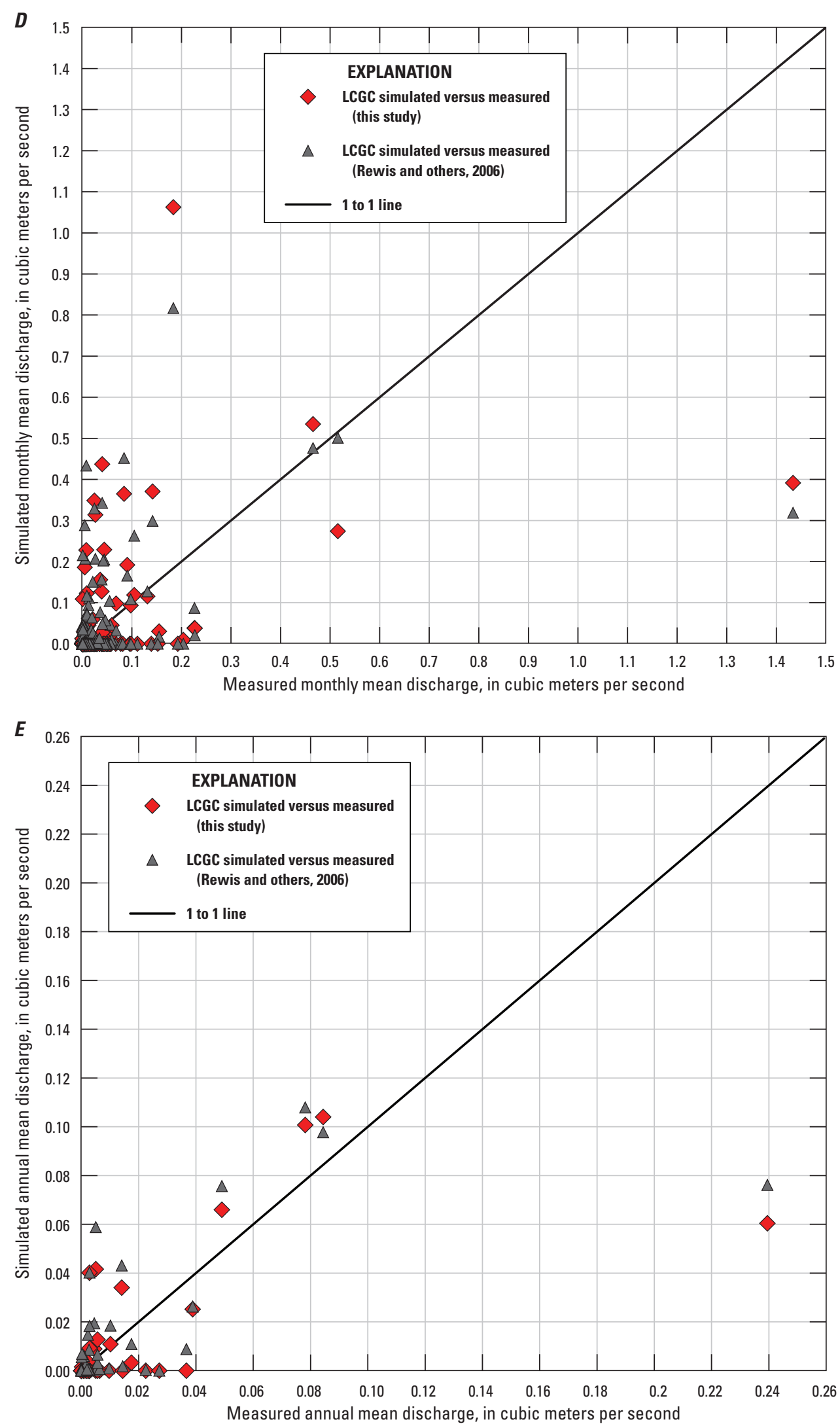

Figure 17. - Continued 
that the SGPWM model developed in this study includes the seepage flow modification to INFILv3, a coarser grid-cell discretization (150-m grid for current study compared to the $30-\mathrm{m}$ grid used in the Rewis model), differences in the daily climate inputs, and modifications to the spatial-interpolation model for the climate inputs (the previous model did not incorporate PRISM maps of average monthly precipitation to interpolate daily precipitation). The overall fit of the SGPWM to the LSGC streamgage was considered adequate on the basis of similarity to results for the Rewis model, which was calibrated in the previous study (Rewis and others, 2006). In terms of estimation bias, the PAEE values of -25 percent for monthly and annual mean discharge indicated a tendency of the model to underestimate streamflow at this site (figs. 17A, $B$ ), whereas the Rewis model indicated less estimation bias, having a PAEE of only -6 percent for mean monthly discharge and -5 percent for mean annual discharge.

The NSME statistics for both models were about zero for monthly flows, indicating a marginal calibration caused mostly by the underestimation of the very high-flow event in 1969, combined with an overestimation of the much smaller peak monthly flows prior to 1969 . The NSME values for annual mean discharge indicated a better match between simulated and measured flows, with a slightly improved fit for the Rewis model $(0.43$ for the Rewis model compared to 0.39 for the SGPWM). The model used in this study provides a better fit to the average monthly mean discharge, however (fig. 17C). The comparison of streamflow at the LSGC streamgage included the very high daily mean discharge value of 33 cubic meters per second $\left(\mathrm{m}^{3} / \mathrm{s}\right)$ measured on February 25, 1969. This high daily mean discharge resulted in a peak monthly mean discharge of about $1.4 \mathrm{~m}^{3} / \mathrm{s}$, as well as a high annual mean discharge of about $0.24 \mathrm{~m}^{3} / \mathrm{s}$. Simulated daily mean discharges for February 25, 1969, were much lower, with about $4 \mathrm{~m}^{3} / \mathrm{s}$ simulated by the Rewis model and about $5 \mathrm{~m}^{3} / \mathrm{s}$ simulated by this model.

The scatterplots of simulated to measured monthly and annual mean discharge indicated the highest estimation error for monthly flows was about $1.0 \mathrm{~m}^{3} / \mathrm{s}$ for both models, and the highest estimation error for annual flows was about $0.16 \mathrm{~m}^{3} / \mathrm{s}$ for both models (figs. 17D, E). The scatterplots indicated a slightly improved fit to measured annual mean discharge by using the previous model, as confirmed by the greater NSME value for the previous model.

\section{San Timoteo Creek near Redlands (STCR)}

Comparison of simulated to measured monthly and annual mean discharge at streamgage STCR indicated an adequate overall fit between simulated and measured streamflow in terms of PAEE, but overestimation of the higher flows during wet years and underestimation of many of the low and intermediate flows during average and dry periods, resulting in poor NSME values of approximately zero for both monthly and annual streamflow (fig. 18A, B). Although the model tended to overestimate the peak monthly flows, resulting in PAEE values of 18 and 19 percent for monthly and annual streamflow, the overall distribution of the average monthly mean discharge was generally represented by the model (fig. 18C). The distribution of annual streamflow for the period of record was also generally represented by the model (fig. 18B). Although there was some overestimation of the largest annual flows and underestimation of the smallest annual flows, the timing and frequency of wet and dry years were sufficiently represented.

The general fit to average monthly streamflow (fig. 18C) showed some deviation from the monthly distribution for January, August, and September. The scatterplots of simulated to measured monthly and annual mean discharge indicated the tendency of the model to overestimate flows at this streamgage, but the overall correlation between simulated and measured streamflow was good, and the model fit was considered sufficient for the purposes of this study (figs. 18D, E).

\section{Snow Creek near White Water (SCWW)}

Comparison of simulated and measured monthly mean discharge at streamgage SCWW indicated an adequate general fit to the wet and dry periods in the monthly streamflow time series (fig. 19A); however, low flows during the spring and summer months was underestimated by the model, as indicated by the comparison of average monthly mean discharge (fig. 19C). In addition, considerable estimation bias was caused by underestimation of streamflow for dry periods, as indicated by the annual mean discharge hydrographs (fig. 19B). The low flows at this streamgage could be springfed baseflows that are difficult for the SGPWM to simulate because there is no deep groundwater discharge component represented by the model. Despite these issues, the monthly and annual streamflow hydrograph (fig. 19A) showed that the model captured the timing and variation in the monthly flows, with a fair match to most, but not all, of the peak flows. The simulation provided acceptable NSME values of 0.42 for monthly flows and of 0.45 for annual flows. The PAEE values of about -40 percent indicated considerable underestimation of streamflow, however.

The scatterplots of monthly and annual streamflow indicated a fair correlation between simulated and measured flows. Comparison of the annual flows indicated a strong model bias in terms of underestimating most of the annual flows, however (figs. 19D, E). The largest absolute estimation errors for annual flows were more than $0.4 \mathrm{~m}^{3} / \mathrm{s}$, for the two greatest measured mean annual discharges of about 0.92 and $0.93 \mathrm{~m}^{3} / \mathrm{s}$.

\section{Chino Canyon Creek below Tramway (CCCT)}

In contrast to the results obtained at SCWW, comparison of simulated to measured monthly and annual mean discharge at streamgage CCCT indicated a tendency of the model to overestimate streamflow at this location, especially for wetter-than-average periods (figs. 20A, B). Although 

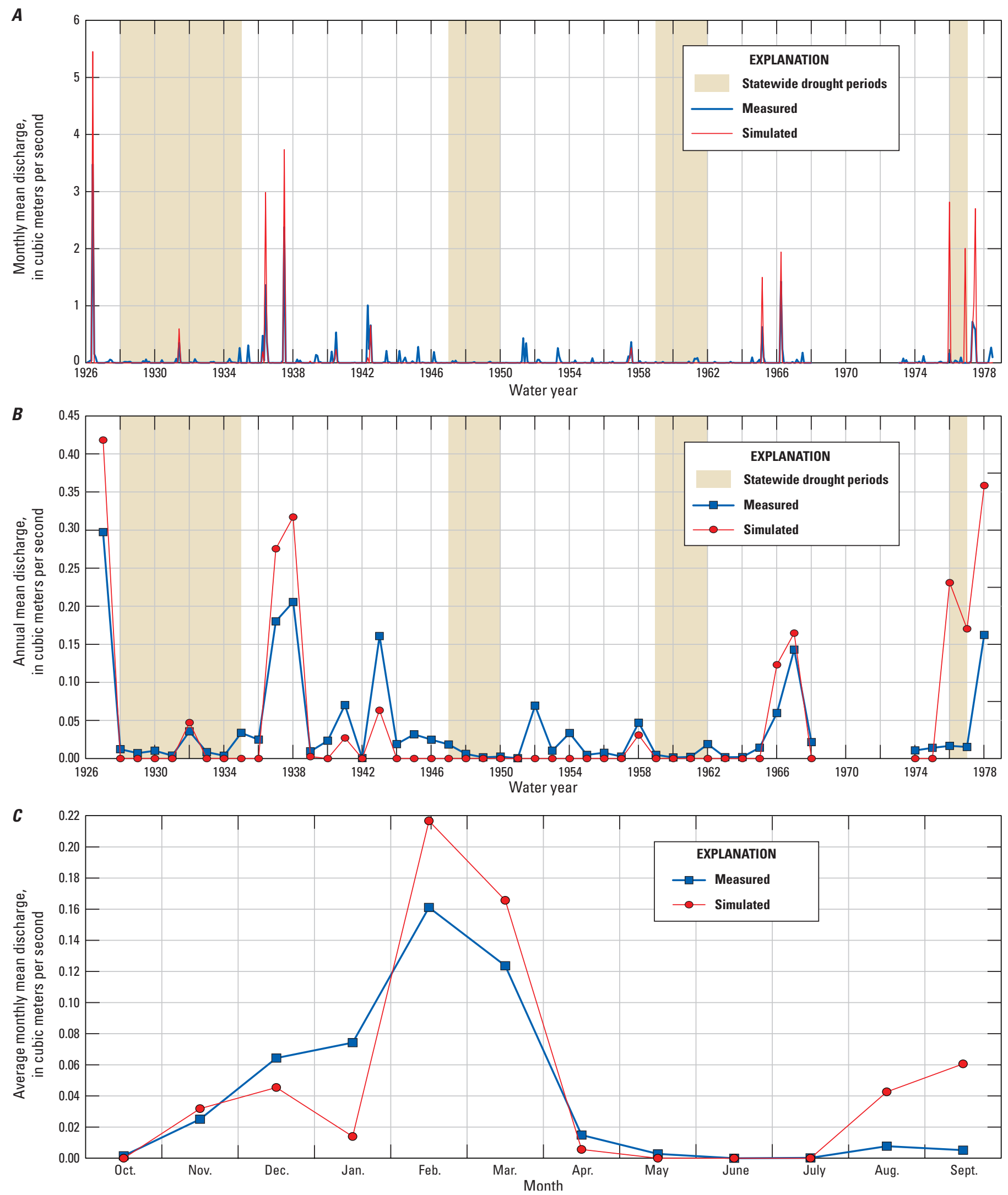

Figure 18. Comparison of simulated and measured streamflow at the San Timoteo Creek near Redlands (STCR) streamgage using the San Gorgonio Pass watershed model, California: $A$, monthly mean discharge; $B$, water year mean discharge; $C$, average monthly mean discharge; $D$, scatterplot of simulated against measured monthly mean discharge; and $E$, scatterplot of simulated against measured water year mean discharge. 

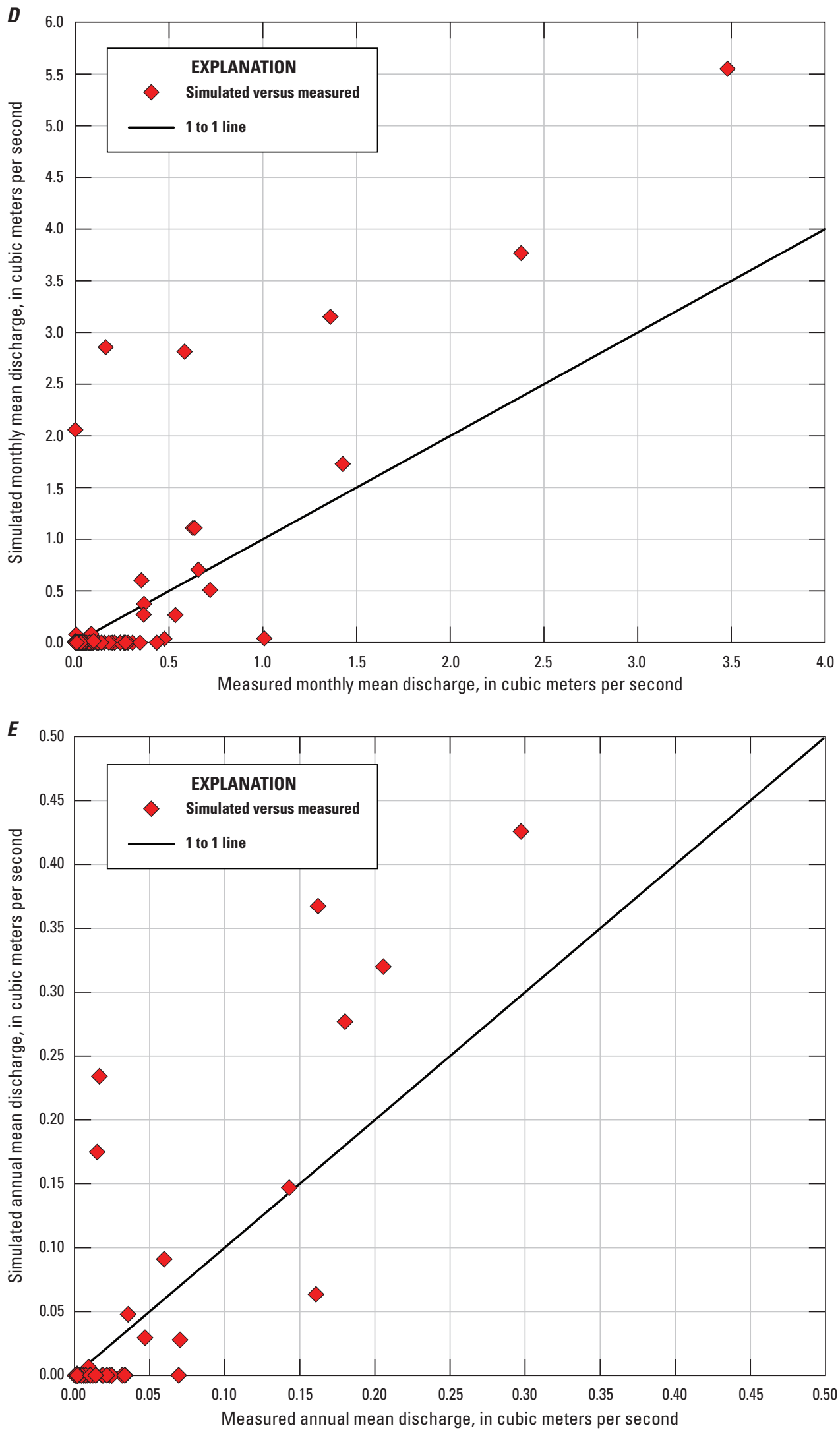

Figure 18. - Continued 

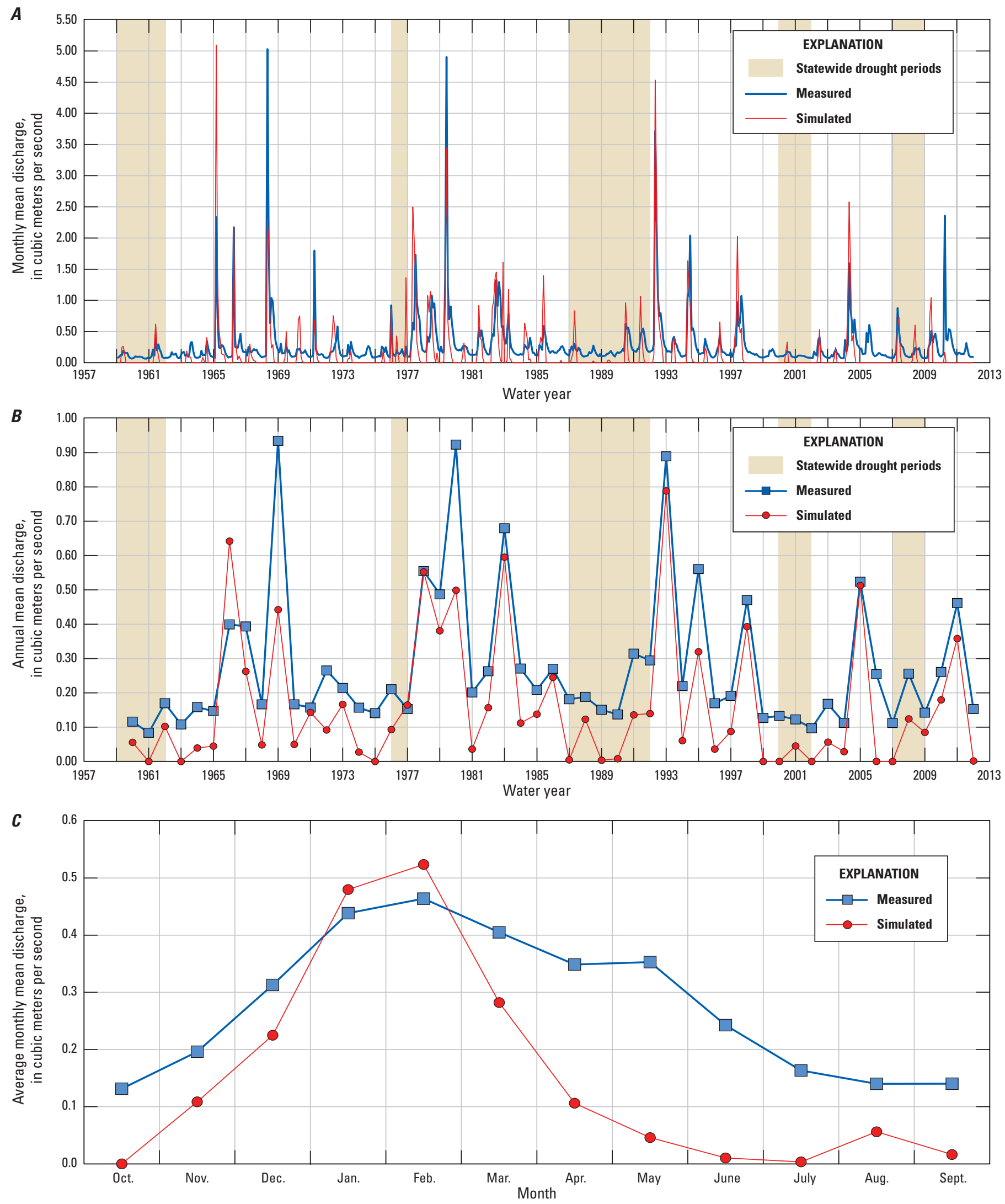

Figure 19. Comparison of simulated and measured streamflow at the Snow Creek near White Water (SCWW) streamgage using the San Gorgonio Pass watershed model, California: $A$, monthly mean discharge; $B$, water year mean discharge; $C$, average monthly mean discharge; $D$, scatterplot of simulated to measured monthly mean discharge; and $E$, scatterplot of simulated to measured water year mean discharge. 

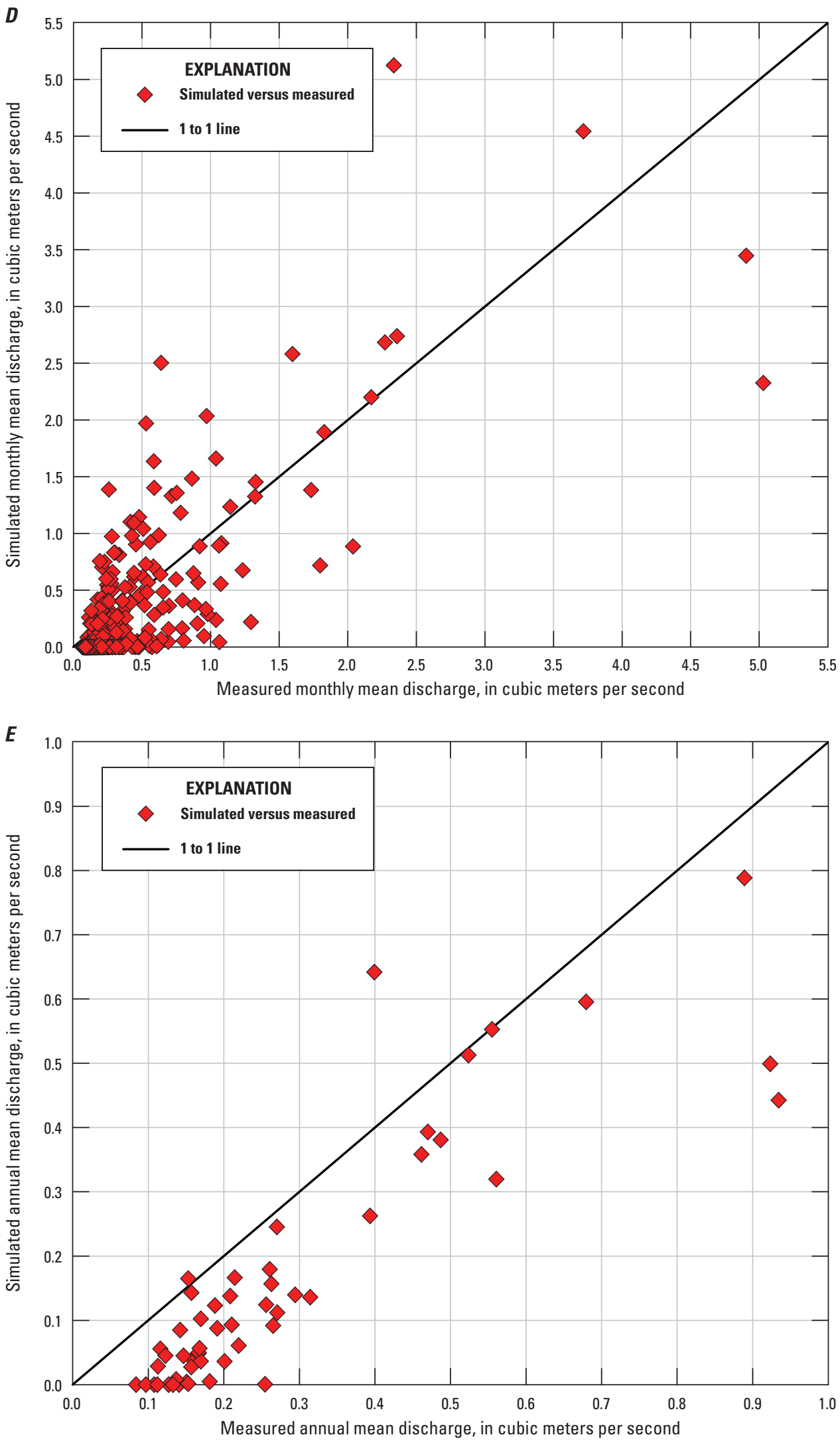

Figure 19. - Continued 

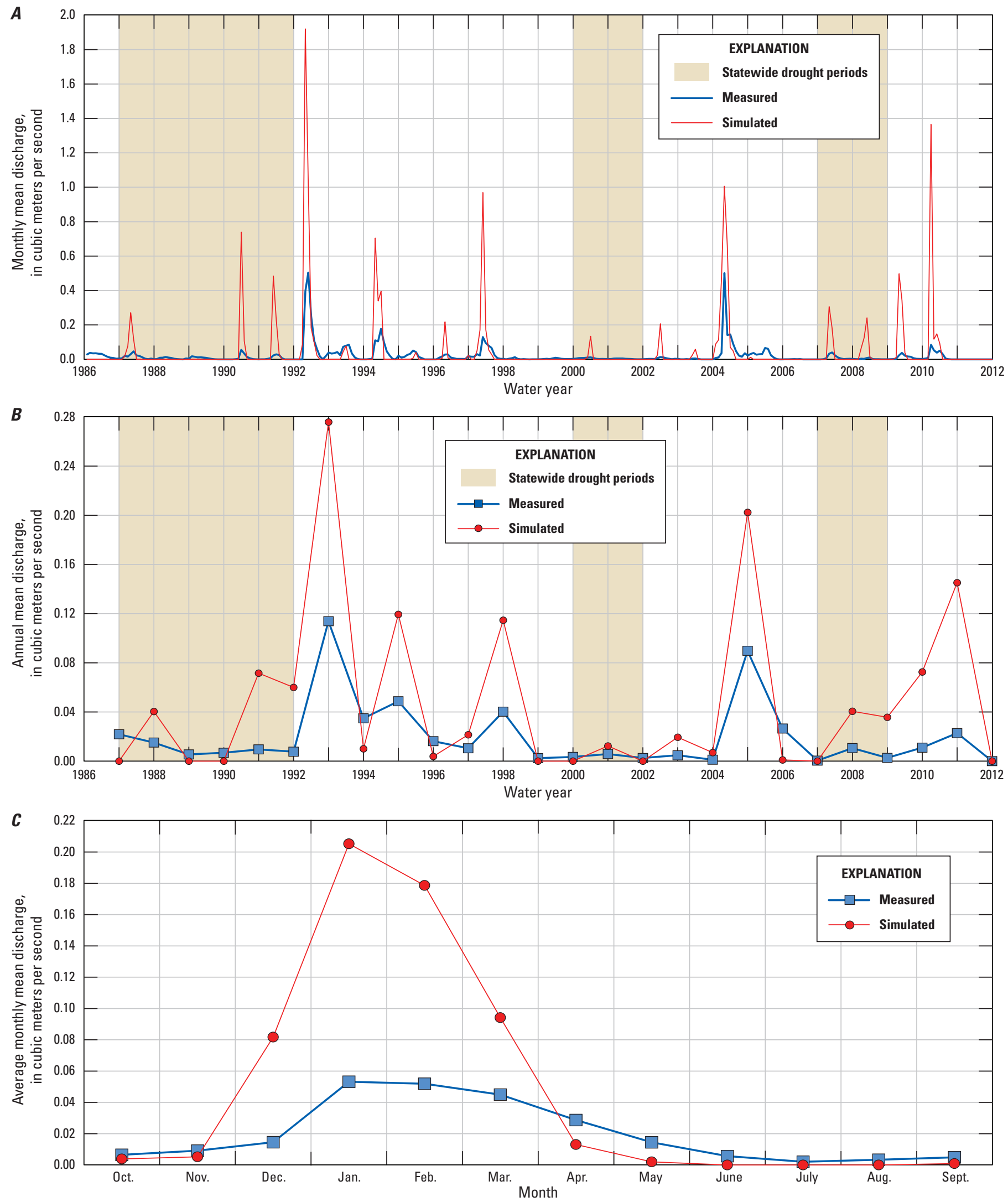

Figure 20. Comparison of simulated and measured streamflow at the Chino Canyon Creek below Tramway (CCCT) streamgage using the San Gorgonio Pass watershed model, California; $A$, monthly mean discharge; $B$, water year mean discharge; $C$, average monthly mean discharge; $D$, scatterplot of simulated to measured monthly mean discharge; and $E$, scatterplot of simulated to measured water year mean discharge. 

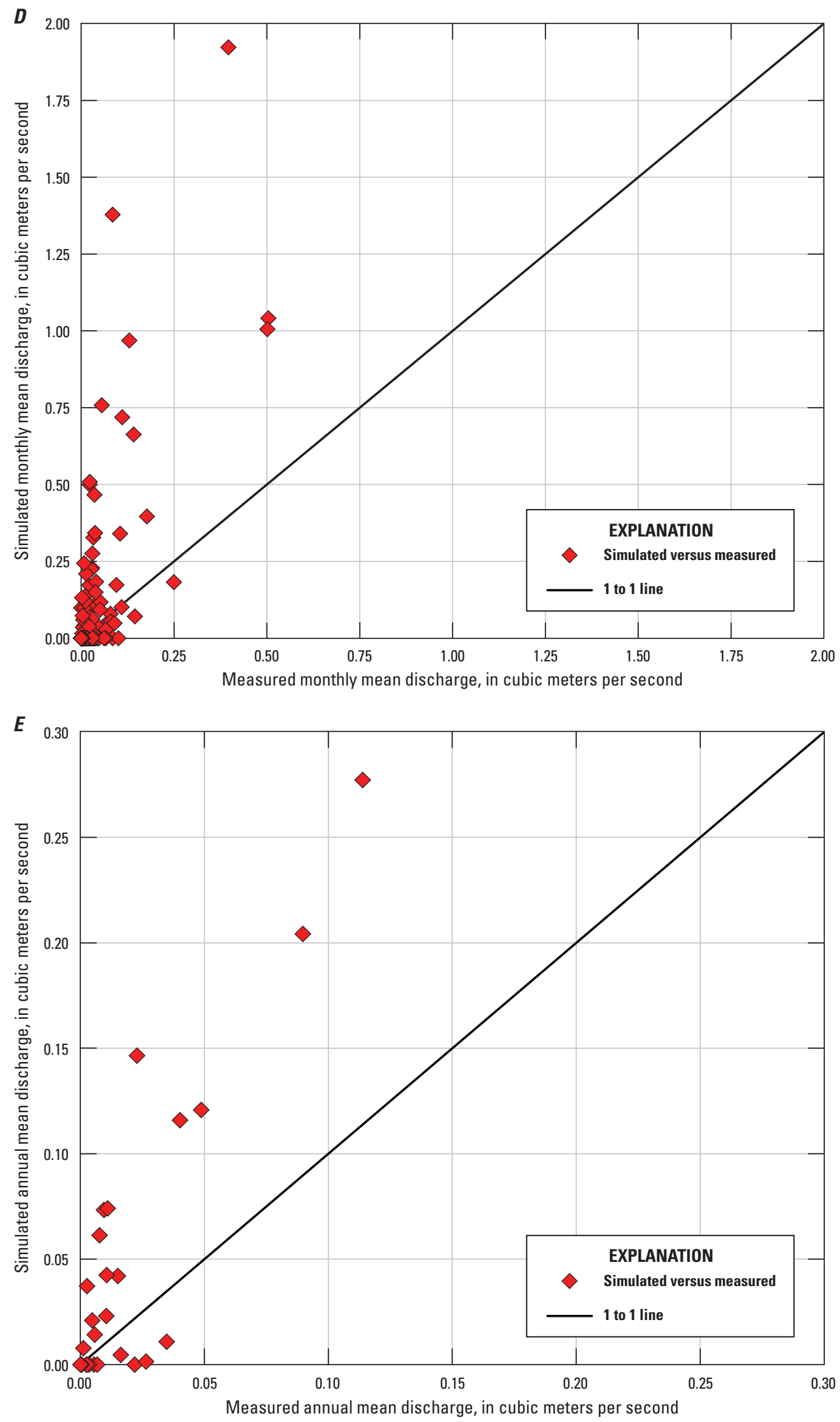

Figure 20. - Continued 
the timing of periods with significant streamflow as well as periods of no streamflow was represented well by the model, the magnitude of peak streamflow was overestimated, which led to a high estimation bias and poor model fit, with PAEE values greater than 100 percent and negative NSME values. The overestimation of flows during the wet winter months was very apparent in the comparison of simulated to measured average monthly mean discharge (fig. 20C). The model provided a fair representation of the monthly distribution of streamflow, however, with January having the highest average monthly streamflow. The model provided a fairly good match to the low average monthly discharge for May through November.

The monthly and annual scatterplots indicated a fair correlation between simulated and measured streamflow, especially for the annual flows; however, the strong bias in terms of overestimating the measured flows was also very apparent. The largest absolute estimation error tended to be for the largest monthly and annual flows.

\section{Tahquitz Creek near Palm Springs (TCNP)}

Comparison of simulated to measured monthly streamflow at streamgage TCNP indicated a good match to monthly mean discharge (fig. 21A). The model indicated a good general fit to annual mean discharge, particularly to most water years that had higher streamflow, such as 1952, 1958, 1978, 1993, 1995, 1998, and 2005, (fig. 21B). The average monthly mean discharge simulated at streamgage TCNP indicated a good fit to measured streamflow for the months of August through January and March, but a poor fit for February and April through July (fig. 21C). February had the highest average monthly mean discharge for simulated streamflow, whereas measured streamflow indicated May had the highest average monthly mean discharge. The difference in peak average monthly streamflow could be caused by the SGPWM underestimating snowfall for the drainage upstream of the TCNP streamgage.

The scatterplots of monthly and annual mean discharge indicated a favorable match between simulated and measured streamflow at this streamgage (figs. 21D, E). Although the PAEE values of -24 percent for monthly flows and -25 percent for annual flows indicated a tendency of the model to underestimate flows at this streamgage, the scatterplots showed a strong correlation between simulated and measured flows; the NSME of 0.49 for monthly mean discharge and 0.83 for annual mean discharge indicated the best overall model fit of the five streamgages used to evaluate model performance.

\section{Summary of Model Calibration Results}

The model provided a satisfactory fit to measured monthly mean discharge, in terms of the NSME statistic, at two of the five streamgages (SCWW and TCNP), and a satisfactory fit to annual mean discharge at three of the five streamgages analyzed (LSGC, SCWW, and TCNP). In terms of the PAEE statistic, the model provided a satisfactory fit to three of the five streamgages (LSGC, STCR, and TCNP) both for monthly and annual mean discharge. The model provided a good fit for two of the five streamgages (LSGC and STCR) on the basis of results for average monthly mean discharge. At streamgages LSGC, SCWW, and TCNP, the model underestimated streamflow, whereas streamflow was overestimated at streamgage STCR and CCCT. The strongest bias in terms of underestimating flow is at streamgage SCWW. There was a fair match to the peak monthly and annual flows at this streamgage, however, resulting in satisfactory NSME values. The strongest bias in terms of overestimating flow was for streamgage CCCT. Out of the five streamgages, model fit was poorest at this streamgage, resulting in negative NSME values. The best overall model fit was obtained at streamgage TCNP, as indicated by the highest NSME results compared to the other streamgages. Although there was a tendency for the model to underestimate flow at this streamgage, as indicated by PAEE values of -24 and -25 for monthly and annual flows, the PAEE values were considered satisfactory. In general, the model calibration results indicated that the application of the SGPWM, which was based on an extension and modification of a model calibrated previously to observed streamflow at streamgage LSGC, was appropriate for the intended use of simulating natural recharge for the SGPGSA.

The NSME statistic is similar to the R-squared statistic in that it provides a standardized indication of model performance, such that the model fit can be compared to results obtained in other studies. For this study area, however, it was difficult to obtain NSME values close to 1.0 simultaneously for all gages because of model limitations regarding the simulation of intermittent streamflow and the sensitivity of streamflow to variability in precipitation and snowmelt in conjunction with highly variability channel properties. Changes in model parameters that would result in an improvement in NSME for one gage would simultaneously cause a deterioration in NSME for another gage. For these reasons, the calibration criteria used for identifying a calibrated model in this study were much less stringent than the criteria commonly used for precipitation-runoff models.

\section{Model Sensitivity}

A qualitative analysis of model sensitivity was done as part of this study. Simulated recharge was found to be most sensitive to soil and root zone thickness, and to the estimated hydraulic conductivity for layers 6 and 7. In most cases, changes in parameter values that caused an increase in recharge also resulted in a decrease in runoff along with a decrease in ET. Runoff, recharge, and ET were all very sensitive to spatially interpolated precipitation as well as the timing and frequency of precipitation. The effect of air temperature on the simulation of precipitation as rain or snow was also found to be a critical input for the higher elevation cells in the San Bernardino and San Jacinto Mountains. Specifically, precipitation as rain tended to cause an increase in streamflow and, subsequently, an increase in recharge resulting from the 

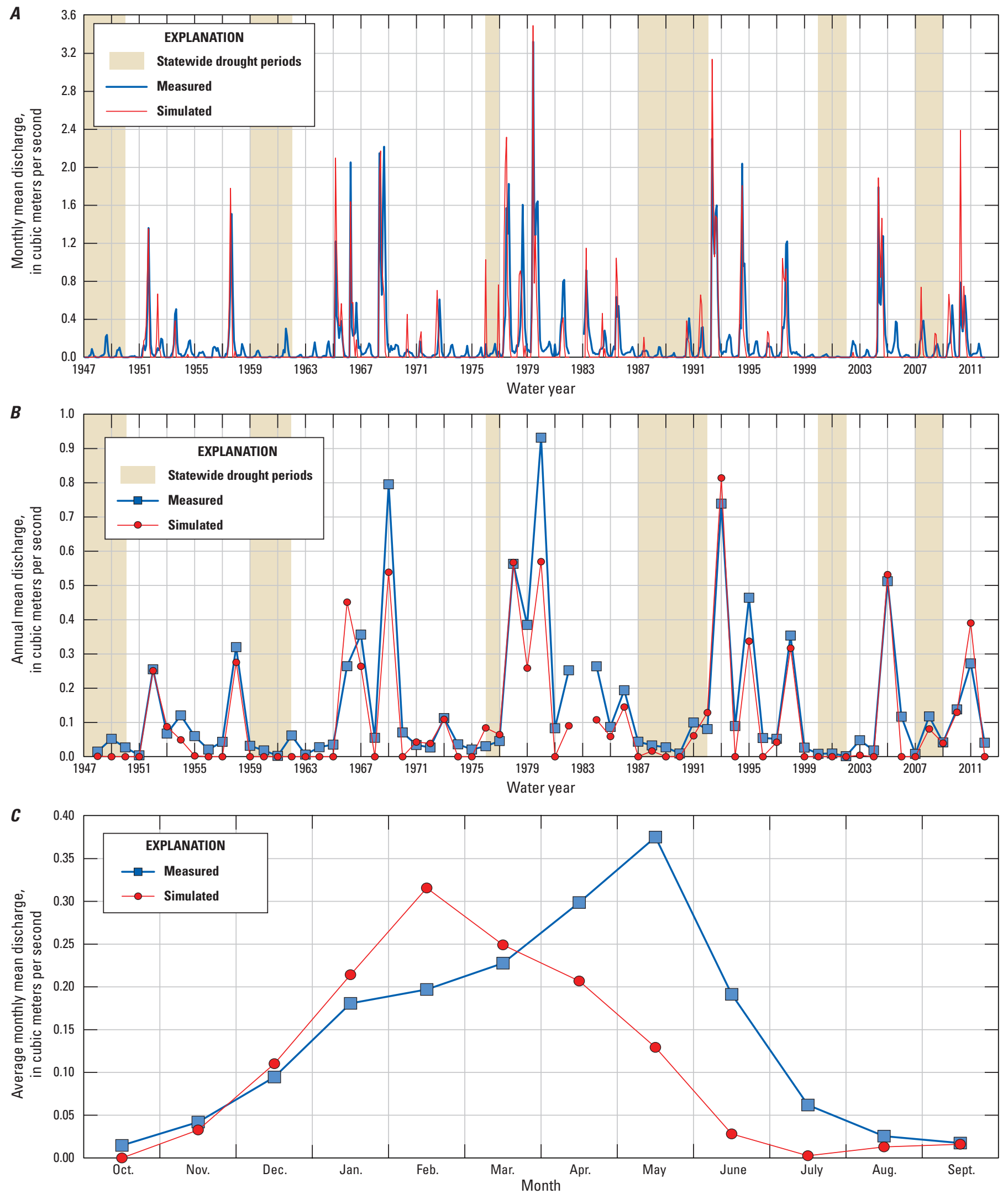

Figure 21. Comparison of simulated to measured streamflow at the Tahquitz Creek near Palm Springs (TCNP) streamgage using the San Gorgonio Pass watershed model, California: $A$, monthly mean discharge; $B$, water year mean discharge; $C$, average monthly mean discharge; $D$, scatterplot of simulated versus measured monthly mean discharge; and $E$, scatterplot of simulated versus measured water year mean discharge. 

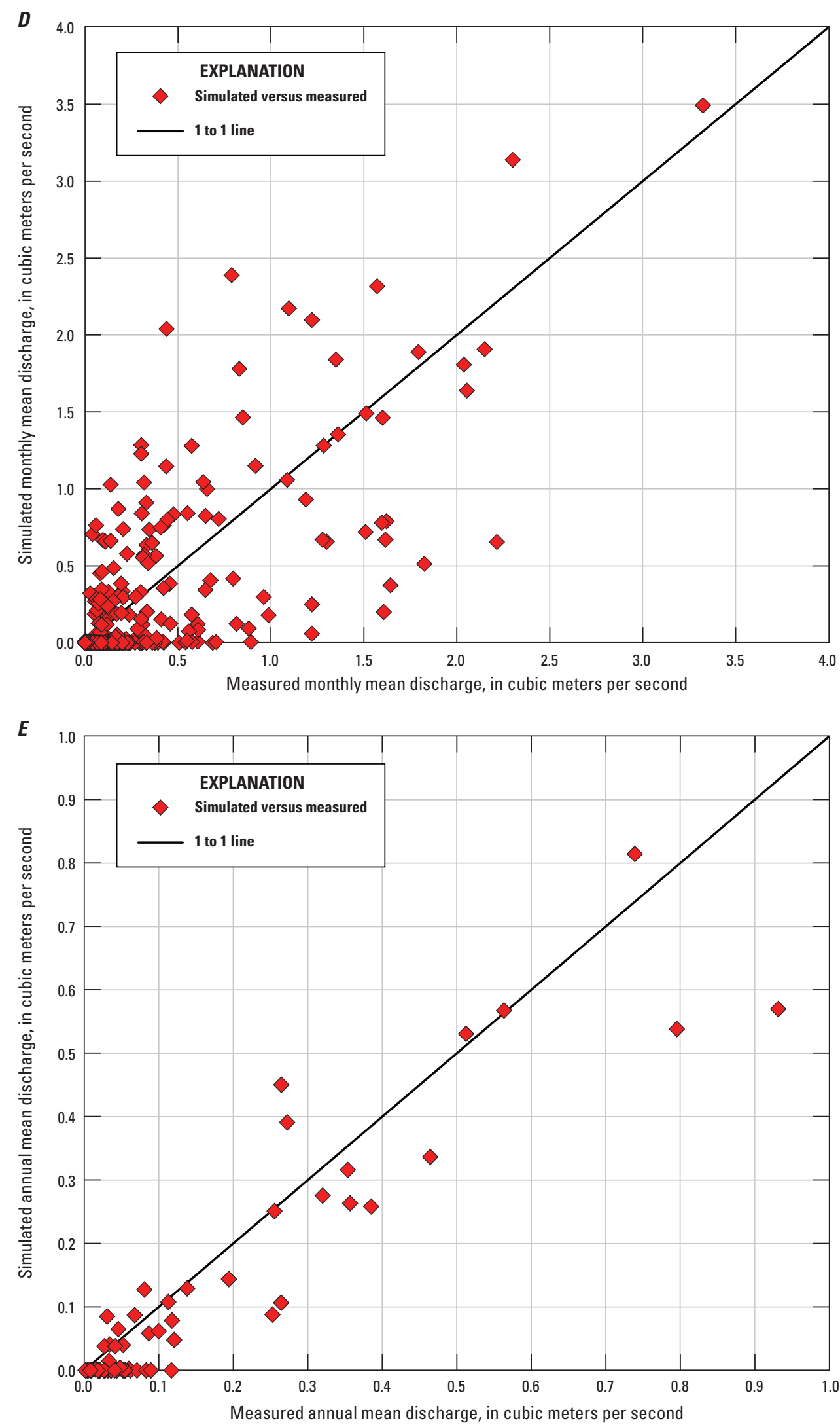

Figure 21. - Continued 
infiltration of streamflow. Precipitation as snow tended to cause a delayed response in runoff and recharge, and this, in turn, usually caused a decrease in runoff and recharge along with an increase in ET. The increased ET occurs because the infiltration of snowmelt into the root zone causes the rootzone water content to be greater in the spring months (March through May) than if the precipitation had been rain. With increased ET, less water is available for recharge and runoff. These observations were generally consistent with findings in previous studies (Flint and Martin, 2012).

On average, areas with thinner soil cover (generally the undeveloped mountainous areas), lower soil hydraulic conductivity, and a higher percentage of impervious areas generated greater runoff. In addition, the frequency and magnitude of runoff was found to be sensitive to the estimated hydraulic conductivity for layer 6 . Low values of hydraulic conductivity for layer 6 resulted in a greater potential for the generation of saturation-excess runoff, or Dunnian runoff (Markstrom and others, 2008), which is runoff that is generated when the storage capacity of the soil has been exceeded. The magnitude and timing of runoff was sensitive to air temperature and precipitation as snow, especially for the higher altitudes, where the percentage of precipitation that is snow was high, and to the layer 7 drainage function coefficients.

The seepage-flow component of simulated streamflow, used in this study to represent laterally redistributed net infiltration below the root zone, was found to be sensitive to the estimated horizontal hydraulic conductivity for layer 7 (defined by the estimated hydraulic conductivity and drainage function coefficients for layer 7) as well as slope. Higher horizontal conductivity and slope resulted in more seepage (and less overland flow). Parameter values that caused increased seepage also tended to cause an increase in ET and a decrease in runoff and recharge.

\section{Model Results}

The simulation period for the SGPWM was from January 1, 1909, through September 30, 2012. The 45-month period from January 1, 1909, through September 30, 1912, was used as the model initialization period. Model results were developed and analyzed for the 100-year target simulation period, from water years 1913 through 2012 (October 1, 1912, through September 30,2012). Results that were analyzed included (1) the long-term average annual water budget, including the spatial variability of average ET, runoff, and recharge rates; (2) the annual water budgets; (3) the average monthly water budgets; (4) mountain front recharge; and (5) the effects of imperviousness on recharge and runoff. In addition, model results developed in this study were compared with results from the Rewis model.

\section{Average Annual Results}

The average annual results for water years 1913-2012 were calculated for all model components to develop an estimate of the long-term historic climate water budget for the SGPWM (table 8). Inflow to the SGPWM from precipitation was 34,171 hectare-meters per year (ha-m/yr). The ET was the largest outflow, averaging 26,632 ha-m/yr. The next largest outflow was recharge at $5,483 \mathrm{ha}-\mathrm{m} / \mathrm{yr}$, followed by runoff at 1,684 ha-m/yr. Sublimation was the smallest outflow component, averaging 343 ha-m/yr. The long-term change in storage (root zone and perched zones combined) was only $28 \mathrm{ha}-\mathrm{m} / \mathrm{yr}$ for the 100-year simulation period. Maps of average annual ET, runoff, and recharge were used to analyze the spatial variability and distribution of these model components and to identify locations of maximum and minimum values.

Table 8. Simulated 100-year water budget using the San Gorgonio Pass watershed model, California: long-term averages for water years 1913-2012.

[Abbreviations: ha-m/yr, hectare-meters per year; mm/yr, millimeters per year; SGPWM, San Gorgonio Pass Watershed Model]

\begin{tabular}{|c|c|c|c|c|c|c|c|c|}
\hline $\begin{array}{c}\begin{array}{c}\text { Average annual } \\
\text { results for the } \\
\text { period 1913-2012 }\end{array} \\
\text { Water- } \\
\text { budget } \\
\text { component }\end{array}$ & \multicolumn{4}{|c|}{ Average depths } & \multicolumn{4}{|c|}{ Average volumes } \\
\hline \multicolumn{9}{|c|}{ Inflows } \\
\hline \multicolumn{9}{|c|}{ Outflows } \\
\hline Evapotranspiration & 363 & 399 & 385 & 387 & 768 & 5,708 & 20,156 & 26,632 \\
\hline Recharge & 85 & 86 & 78 & 80 & 180 & 1,238 & 4,066 & 5,483 \\
\hline Runoff & 1.2 & 5.2 & 31 & 24 & 2.6 & 75 & 1,607 & 1,684 \\
\hline Sublimation & 0.0 & 2.8 & 5.8 & 5.0 & 0.1 & 40 & 303 & 343 \\
\hline Sub-total & 449 & 493 & 499 & 496 & 950 & 7,061 & 26,132 & 34,143 \\
\hline Sub-total & -0.5 & -0.0 & 0.6 & 0.4 & -1.0 & -0.3 & 29 & 28 \\
\hline
\end{tabular}




\section{Evapotranspiration}

ET is the primary outflow of water from the SGPWM, with a basin-wide average of $387 \mathrm{~mm} / \mathrm{yr}$ for the 100 -year simulation period, about 78 percent of the basin-wide average precipitation of $496 \mathrm{~mm} / \mathrm{yr}$ (fig. 22; table 8). The modeled average ET values for the three model subdomains were similar: the San Timoteo Creek subdomain had the highest basin-wide average ET at $399 \mathrm{~mm} / \mathrm{yr}$, and the Potrero Creek subdomain had the lowest basin-wide average ET at $367 \mathrm{~mm} / \mathrm{yr}$. The mapped results for all cells indicated a minimum average ET of about $100 \mathrm{~mm} / \mathrm{yr}$ in the southeastern part of the Indio HSA and a maximum average ET of about $1,200 \mathrm{~mm} / \mathrm{yr}$ for a stream channel on a south-facing slope near the summit of Little San Gorgonio Peak (fig. 22). The simulated average ET was least in the Indio HSA, where the soil was the thinnest, the vegetation cover was sparse, and precipitation was the least. In the San Bernardino Mountains, average ET was much less for north-facing slopes compared to that of south-facing slopes. For many areas of the SGPWM, the greatest average ET was simulated for stream channels, where the root zone extends the deepest and the availability of water in the root zone is maximized in response to infiltrating streamflow.

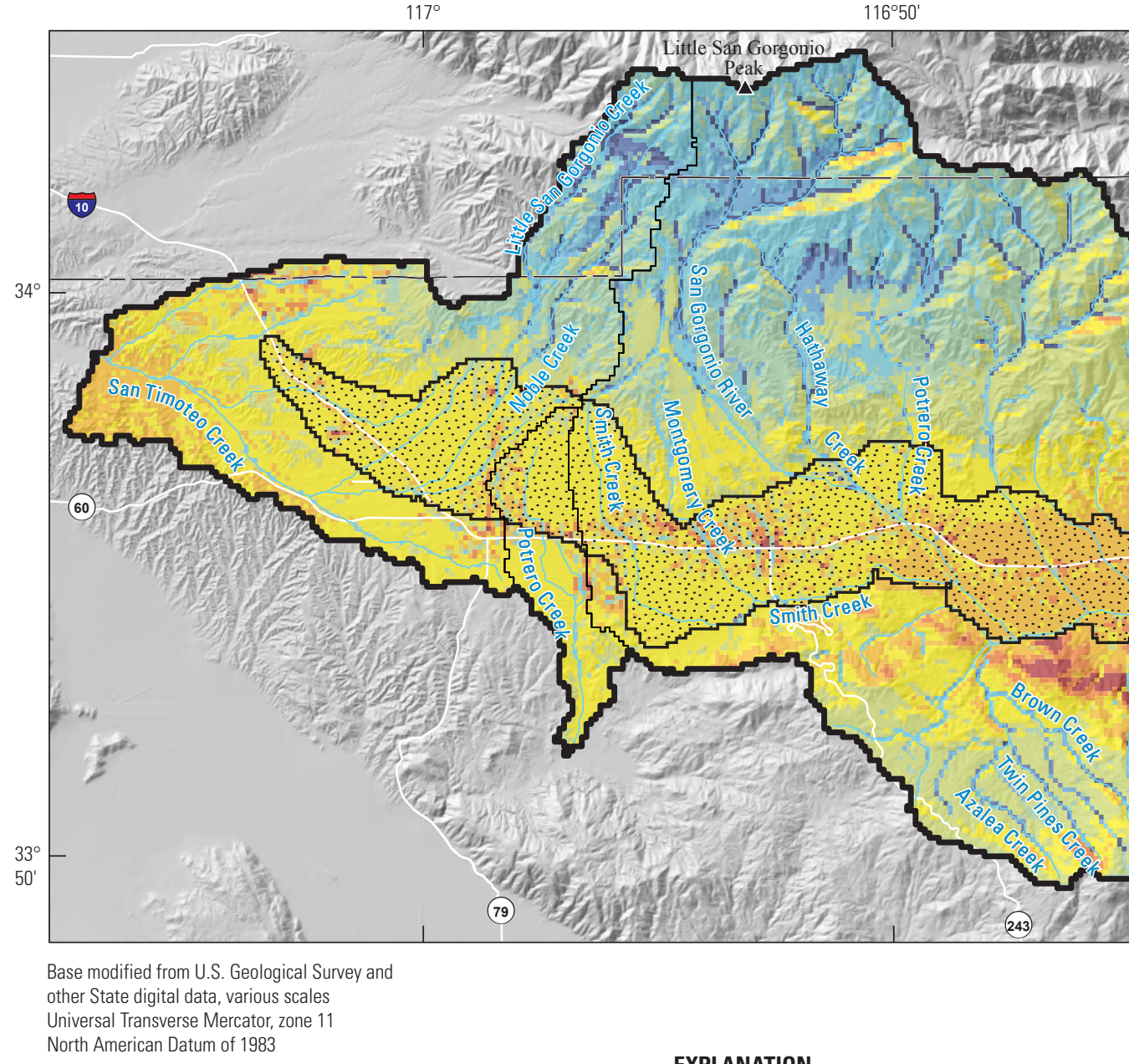

$117^{\circ}$

$116^{\circ} 50^{\prime}$

$116^{\circ} 40^{\prime}$

other State digital data, various scales

North American Datum of 1983

EXPLANATION

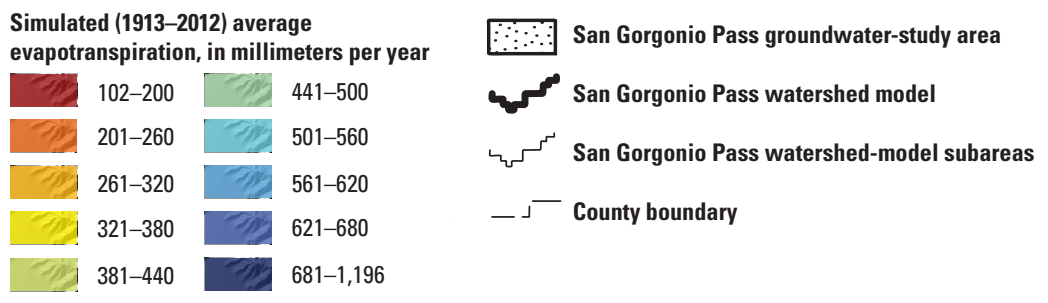

Figure 22. Average annual evapotranspiration simulated for water years 1913-2012 using the San Gorgonio Pass watershed model, California. 


\section{Runoff}

The 100-year basin-wide average simulated runoff for the SGPWM for water years 1913-2012 was $24 \mathrm{~mm} / \mathrm{yr}$ (table 8), indicating that about 5 percent of precipitation falling in the SGPWM was discharged as surface-water runoff to areas downstream of the SGPWM. Basin-wide average runoff for the San Gorgonio River subdomain was much greater than the basin-wide average runoff for the Potrero Creek and San Timoteo subbasins because of the thinner soils, more precipitation at the higher altitudes of Little San Gorgonio Peak and San Jacinto Peak, and steeper slopes of the San Gorgonio River subbasin. The map of simulated average runoff depth indicated the average depth of surfacewater runoff for the 100-year simulation period over the $2.25 \mathrm{ha}(150 \mathrm{~m} \times 150 \mathrm{~m}=2.25 \mathrm{ha})$ area of each model cell (fig. 23). The average annual runoff depth for each cell can be represented as daily flow volumes of cubic meters per day by multiplying the runoff depth (in meters) by the cell area (2.25 ha equals 22,500 cubic meters) and dividing by 365.25 days. Results indicated that maximum average runoff was simulated for the cells representing the main channels of the San Timoteo and San Gorgonio Rivers. Relatively high average annual runoff depths of 50,001 to $720,000 \mathrm{~mm} / \mathrm{yr}$ (3,100 to 44,000 cubic meters per day; $\left.\mathrm{m}^{3} / \mathrm{d}\right)$ were simulated for the lower sections of the San Gorgonio River, and high average annual runoff depths of 10,001 to $50,000 \mathrm{~mm} / \mathrm{yr}(616$ to $3,100 \mathrm{~m}^{3} / \mathrm{d}$ ) were also simulated for the lower section of San Timoteo Creek. Simulated average annual runoff in the main channels of the subdrainages in the upland areas of Little San Gorgonio Peak and San Jacinto Peak varied from 1,001 to $50,000 \mathrm{~mm} / \mathrm{yr}$ (62 to $\left.3,100 \mathrm{~m}^{3} / \mathrm{d}\right)$.

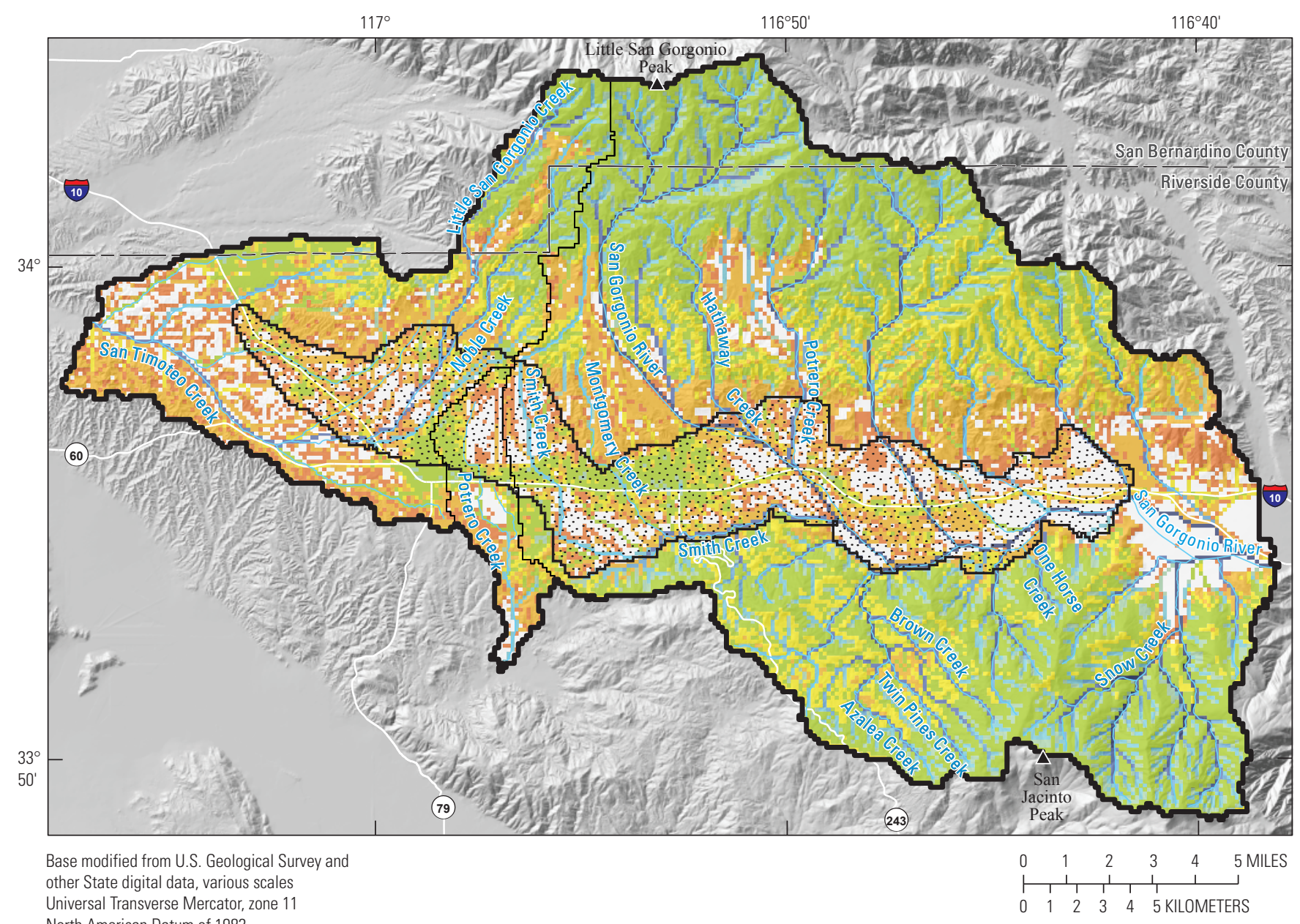

North American Datum of 1983

EXPLANATION

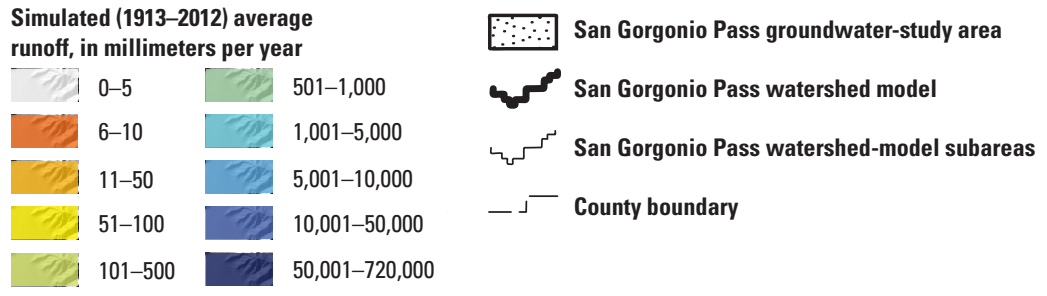

Figure 23. Average annual runoff simulated for water years 1913-2012 using the San Gorgonio Pass watershed model, California. 


\section{Recharge}

The basin-wide average annual recharge simulated for the SGPWM for water years 1913-2012 was $80 \mathrm{~mm} / \mathrm{yr}$ for the SGPWM and was about 16 percent of the basin-wide average annual precipitation for the SGPWM (table 8). High average recharge rates of more than $200 \mathrm{~mm} / \mathrm{yr}$ were simulated for larger stream channels underlain by alluvium, such as Smith Creek, Noble Creek, San Timoteo Creek, Potrero Creek, and San Gorgonio River (fig. 24). High average recharge of about $200 \mathrm{~mm} / \mathrm{yr}$ and greater was also simulated for the intrachannel areas of high-altitude alluvial valleys such as Potrero Creek, San Gorgonio River, Smith Creek, and Noble Creek, and for locations at the base of side slopes, at the transition from areas with low permeability bedrock to areas with more permeable alluvium. Low average recharge of less than $21 \mathrm{~mm} / \mathrm{yr}$ was simulated for much of the south-facing slope of Little San Gorgonio Peak, where a greater percentage of precipitation became runoff or was lost to ET. In the area of the SGPGSA, most of the intra-channel locations had average recharge rates ranging from 51 to $200 \mathrm{~mm} / \mathrm{yr}$. The greatest average recharge in the SGPGSA was along the channel of Noble Creek and San Gorgonio River. Isolated areas that had low average recharge (less than $21 \mathrm{~mm} / \mathrm{yr}$ ) were in locations having a high percentage of impervious areas.

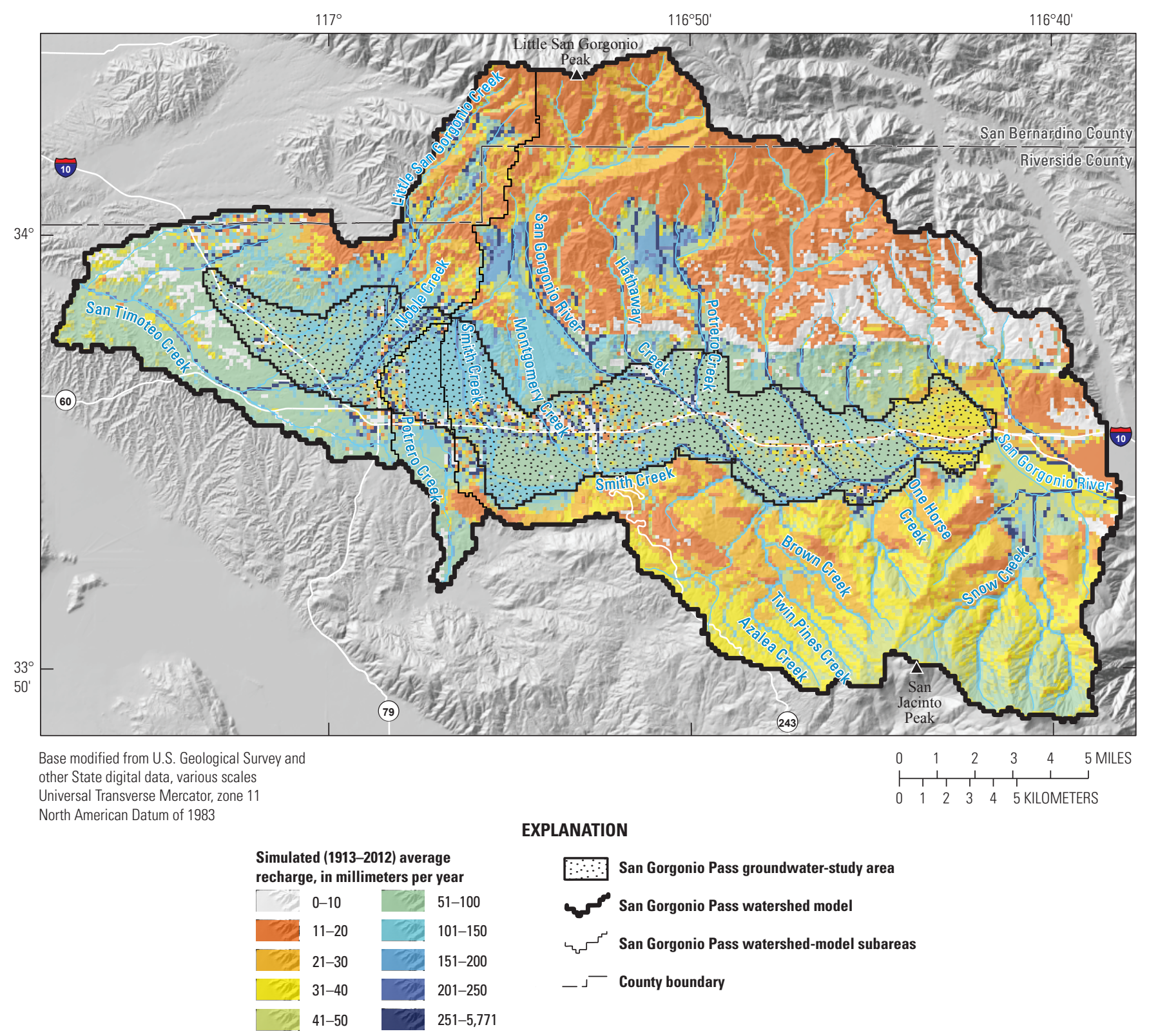

Figure 24. Average annual recharge simulated for water years 1913-2012 using the San Gorgonio Pass watershed model, California. 


\section{Annual Results}

The time series of spatially averaged annual water budgets simulated for water years 1913 through 2012 indicated high year-to-year variability in all water-budget components (fig. 25). The spatial averages were calculated by summing the annual results (based on water years) for all 30,595 model cells and dividing by the number of cells. The annual water budget includes inflows from precipitation; changes in storage (root zone and perched zone combined); and outflows from ET, recharge, surface water discharge (runoff), and sublimation. In order to illustrate a balanced water budget for the annual results shown in figure 25, where inflows equal outflows for each water year, decreases in storage were shown as inflows from storage, and increases in storage were shown as outflows to storage (an increase in storage is an outflow in the water budget, and a decrease in storage is an inflow in the water budget). Overall, the annual water budgets indicated a trend of increasing variability in response to increasing variability in precipitation. The four wettest years $(1978,1983,1993$, and 2005) and three out of the four driest years $(2002,2007$, and 2009) were all after water year 1978. The wettest year (1993) and the three driest years $(2002,2007$, and 2009) were after water year 1992.

Water years with high precipitation are balanced by high ET, recharge, and runoff. ET was the largest outflow in the water budget for all water years. The highest ET was $650 \mathrm{~mm}$ (shown as $-650 \mathrm{~mm}$ to indicate that this was an outflow) and was in water year 1983, which was the second wettest year in the simulation period, with an annual precipitation of $1,010 \mathrm{~mm}$. Simulated ET exceeded precipitation for 17 of 100 water years, and all of the 17 years had less than average precipitation.

The magnitude of annual recharge and runoff tended to be directly correlated with the magnitude of annual precipitation. The maximum annual recharge of about $400 \mathrm{~mm}$ and the maximum annual runoff of about $250 \mathrm{~mm}$ were both simulated for water year 1993, the wettest year in the period at about $1,100 \mathrm{~mm}$ of precipitation. ET was not strongly correlated to precipitation, but was weakly dependent on air temperature. In contrast to the greatest simulated ET of $642 \mathrm{~mm}$ for 1983, simulated ET for 1993, the wettest year in the period, was only $436 \mathrm{~mm}$. The differences in the temporal distribution of ET relative to recharge and runoff result from differences in the timing, frequency, and magnitude of daily precipitation, combined with year-to-year variations in air temperature affecting PET.

Changes in storage (the combined change in storage of the root zone and perched zones) and sublimation were the smallest components of the annual water budgets, and the amount of sublimation was much smaller than changes in storage, averaging just $5 \mathrm{~mm} / \mathrm{yr}$ for the SGPWM (table 8). With the exception of water year 2008, no water years with less than $400 \mathrm{~mm}$ precipitation indicated a gain in water storage (outflow to storage). The increase in storage (outflow to storage) for water year 2008, a somewhat drier than average year with about $363 \mathrm{~mm}$ precipitation (compared to $496 \mathrm{~mm}$ for an average year), resulted because it followed the driest water year in the simulation period, water year 2007, with only $94 \mathrm{~mm}$ precipitation. The greatest increases in annual storage were for wetter than average years that followed drier than average years, and the largest decreases in storage were for drier than average water years that followed wetter than average water years.

To evaluate annual variability as well as trends and deviations from the averages for the 100-year (yr) period, the annual time series for ET, recharge, and runoff were analyzed by using the 11-year centered moving-average and also the LOWESS method (fig. 26). Results indicated periods of greater than average ET for water years 1917-45, water years 1976-86, and water years 1992-95 (fig. 26A). Very low values of annual ET less than $150 \mathrm{~mm}$ were simulated for water years 2002 and 2007, the 2 driest years of the simulation period. Year-to-year variations in ET for water years 1913-46 were less than for the rest of the period because average precipitation was greater for this period than other periods. In addition, average air temperatures were lower during this earlier period, which resulted in greater amounts of snowfall than during other periods (figs. 14B, C). ET was greater during this earlier period compared to the long-term average, even though PET was lower, mostly because of the lower air temperatures (fig. 14D), because of the greater water availability and because snowmelt contributes more to ET than precipitation falling as rain. Winter seasonal rainfall promotes runoff and recharge, whereas snowfall during the winter causes a delay in water availability (as snowmelt) into spring, when PET is higher, promoting higher ET and, correspondingly, decreased runoff and recharge.

Annual recharge indicated greater year-to-year variability than did ET, with relatively high annual recharge of 250 $\mathrm{mm}$ and greater simulated for water years 1922, 1937, 1969, 1978,1980 , and 1993, compared to very low recharge of $50 \mathrm{~mm}$ and less simulated for 54 of the 100 (a little more than half) water years (fig. 26B). Periods of greater than average recharge tended to be short (1 to 3 years), whereas periods of below-average recharge tended to be longer (3-7 years in most cases). Water year 1993, the wettest year in the simulation period, also had the most annual recharge at $380 \mathrm{~mm}$, and it was followed by a year that had below-average recharge of $45 \mathrm{~mm}$.

Annual runoff indicated year-to-year variability similar to that of recharge (fig. 26C). Unlike recharge, however, very small annual runoff amounts of less than $1 \mathrm{~mm}\left(0.02 \mathrm{~m}^{3} / \mathrm{s}\right)$ were simulated for many years, causing the year-to-year variability in the annual time series of runoff to be greater than the variability for recharge. Periods of 6 years or longer that had less than average annual runoff were water years 1944-57, 1959-65, 1970-75, 1984-92, and 1999-2004. Similar to recharge, periods with greater than average runoff were very short (1 to 3 years), and only two 3 -year periods had greater than average runoff: 1914-16 and 1978-80. In general, the overall variability in annual runoff was the greater than that of the other model components, and the maximum annual runoff was about $250 \mathrm{~mm}\left(5.45 \mathrm{~m}^{3} / \mathrm{s}\right)$ for water year 1993 . 


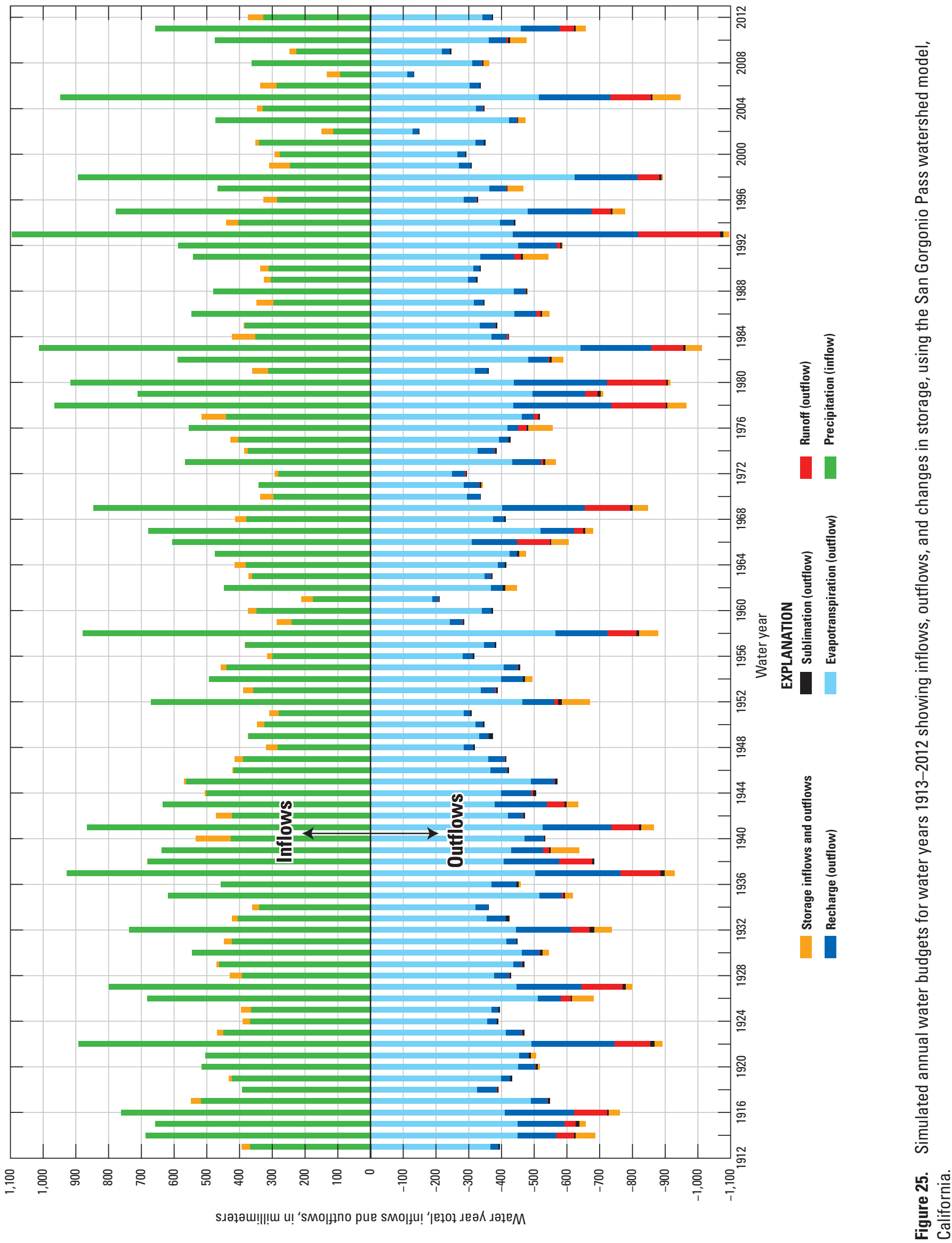


$\boldsymbol{A}$

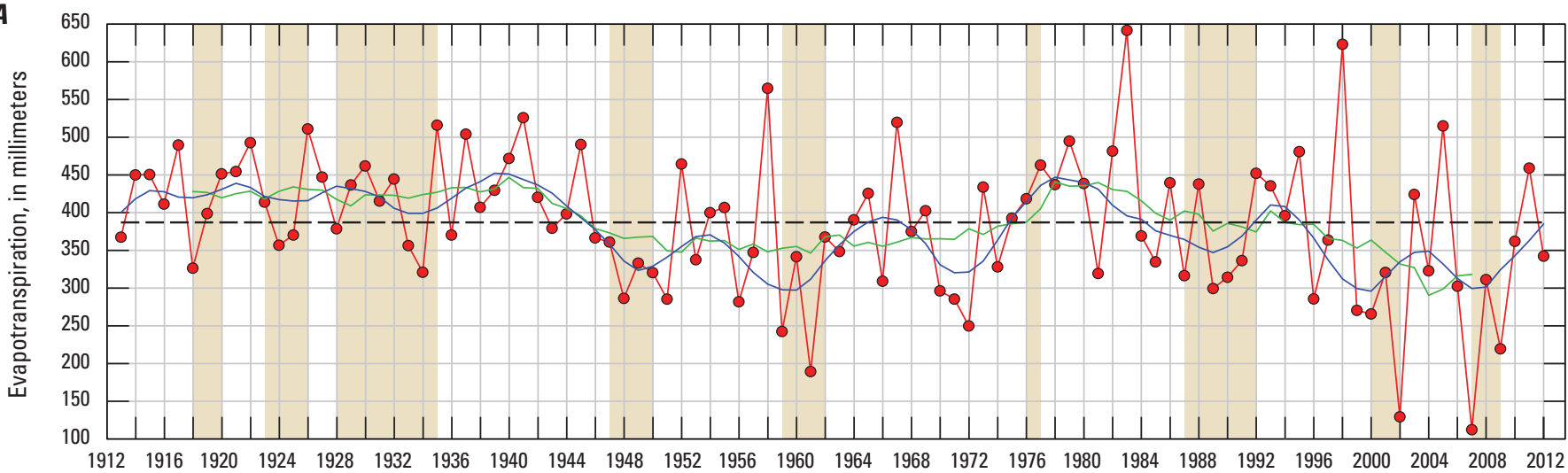

$\boldsymbol{B}$

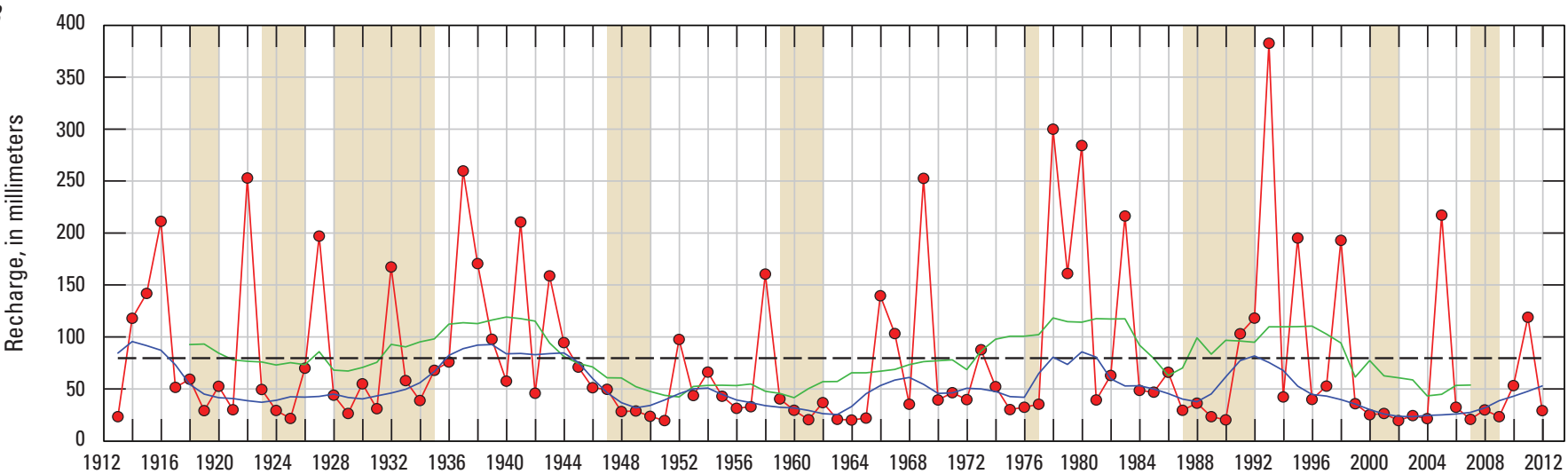

C

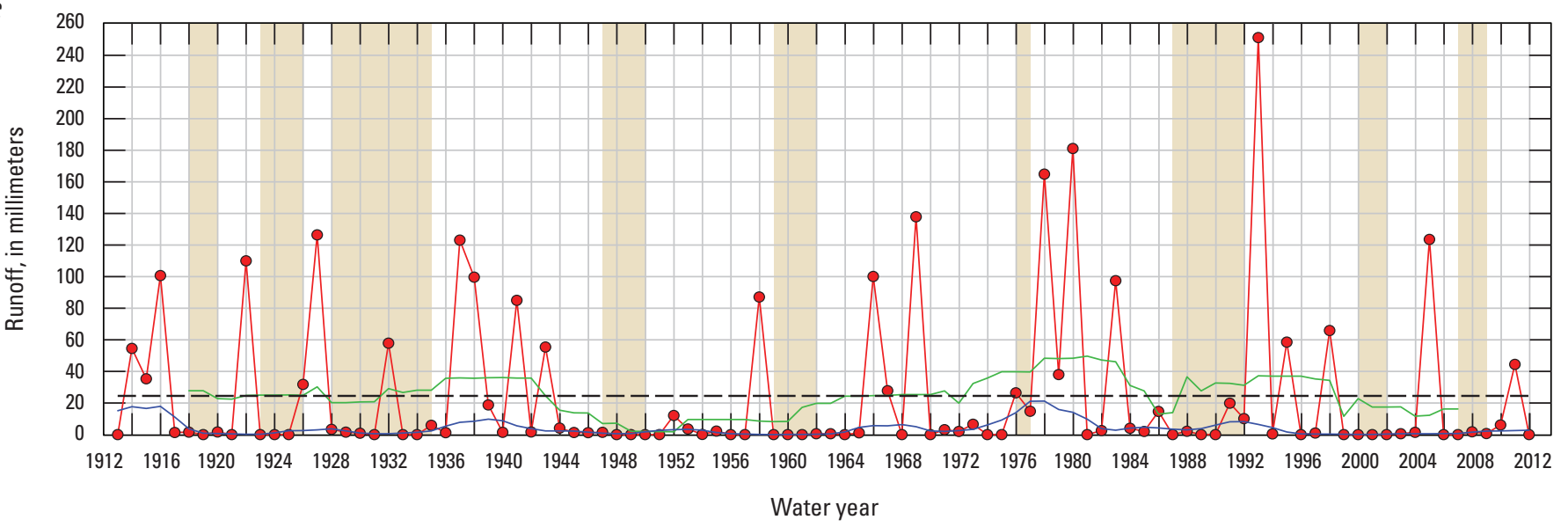

EXPLANATION

Statewide drought periods $\longrightarrow$ Annual

LOWESS $\quad$ 11-year moving average

- - 100-year average

Figure 26. Annual simulation results for water years 1913-2012, using the San Gorgonio Pass watershed model: $A$, evapotranspiration; $B$, recharge; and $C$, runoff. 
The 11-year moving average for ET indicated wet and dry periods very similar to those indicated by LOWESS (fig. 26A). Prior to water year 1936, both curves indicated a poor correlation to state-wide dry periods identified by the DWR drought periods. After water year 1936, there was a better match between periods of low ET and the DWR drought periods. In contrast to ET, results for recharge and runoff indicated a greater difference between the 11-year moving average and LOWESS relative to the 100 -year period average (figs. 26). Although the wet and dry periods indicated by the two curves were similar both for recharge and runoff, the LOWESS curve for recharge had values above the 100-year average for some water years, whereas the LOWESS values for runoff were all below the 100-year mean for runoff. The 11-year moving average indicated wetter than average periods (values greater than the 100-year mean), both for recharge and runoff, for water years 1932-43, 1973-84, and 1988-98. The 11-year moving average and LOWESS curves differed because the 11-year moving average is sensitive to outliers (very wet years or very dry years), which tend to be episodic.

The 11-year moving average and LOWESS curves are useful for identifying patterns in the annual time series of the selected water-budget components. The wet and dry periods indicated by both curves are dependent on the parameters used to define the curves, however, and are therefore subjective. The cumulative departure from the mean is often used to identify long-term trends and deviations in the annual time series of selected water-budget components, where a positive slope in the cumulative departure indicates wetter than average periods, and a negative slope indicates drier than average periods.

The cumulative departure from the mean was analyzed for precipitation, ET, recharge, and runoff (fig. 27). Precipitation was wetter than average periods for water years 1913-45, 1977-83, and 1990-98 and drier than average for water years 1946-77, 1984-90, and 1998-2012 (fig. 27A). Annual ET deviations from mean ET were strongly correlated to the wet and dry precipitation periods (figs. $27 A, B$ ). Unlike ET, annual recharge and runoff did not correlate as well to the initial period of greater than average precipitation, although there was a distinct period of greater than average recharge from water years 1936 to 1944 (fig. 27B). After 1944, the periods of more and less recharge and runoff were well matched to the wet and dry periods for precipitation (fig. 27). The difference in the cumulative departure curves in the earlier part of the simulation period was caused, in part, by the trend of decreasing snowfall discussed previously and the effect of snowfall as opposed to rain on ET, recharge, and runoff.

The spatial distribution of simulated annual recharge for a wet year (water year 1993) and a dry year (water year 2004) were compared (fig. 28). Water year 1993, the wettest year at 1,095 $\mathrm{mm}$ annual precipitation, also had the highest simulated annual recharge at $383 \mathrm{~mm}$ (table 9). Water year 2004 was a drier than average year, at $330 \mathrm{~mm}$ annual precipitation, and also had the eighth lowest annual recharge amount at $21 \mathrm{~mm}$ (table 10). Water year 2004 was selected for analysis because it was the last year in a relatively long (6-year) period of little recharge and also had the lowest combined recharge indicated by the 11-year moving average, at $45 \mathrm{~mm}$, and by the LOWESS curve value of $25 \mathrm{~mm}$ (fig. 26B).

For water year 1993, recharge in the SGPGSA ranged from 201 to more than $501 \mathrm{~mm}$ for inter-channel locations (fig. 28A), whereas it ranged from 0 to $50 \mathrm{~mm}$ for water year 2004 (fig. 28B). For mountain block locations with thin soil, water year 1993 recharge was limited by the permeability of the underlying bedrock and, therefore, was similar to the long-term average recharge (fig. 24). Most of the increased recharge for water year 1993 was in areas with thick soils and alluvium, where recharge was not limited by the permeability at the bottom of the root zone. In contrast to water year 1993, recharge for water year 2004 was mostly in the mountainous areas, especially the north-facing slope of San Jacinto Peak. Recharge was less than $2 \mathrm{~mm}$ for widespread areas having thick soils, including areas with thick soils at the higher altitudes of the San Bernardino Mountains.

\section{Average Monthly Results}

Average monthly simulation results for precipitation, ET, recharge, runoff, and change in storage were used to analyze the monthly and seasonal variability in the simulated water budget (fig. 29A). The average monthly results were calculated by summing the monthly results for a given month for all 30,595 model cells for water years 1913 through 2012 and dividing by the number of model cells and the number of months in the 100-year period $(1,200)$. March had the greatest average monthly recharge and ET rates were in March, about 15 and $75 \mathrm{~mm}$, respectively. The average monthly precipitation and runoff rates were greatest in February, at about 100 and $10 \mathrm{~mm}$, respectively. Average monthly recharge and ET were highest during March because the average monthly water content of the root zone also was at a maximum during March. The root zone tended to have the largest increase (outflow) in water content during December and the largest decrease (inflow) in water content during April. The maximum increase in the perched-zone water content, about $8 \mathrm{~mm}$, was during February, and the largest decrease (inflow) in the perched-zone water content, about $3 \mathrm{~mm}$, was during May.

For a given water year, the monthly distribution of simulated water budget components can be much different than the long-term average distribution indicated in figure $29 \mathrm{~A}$. Monthly simulation results for the wetter than average water year 1993 (1,095 mm precipitation) indicated a much wetter than average January, with $521 \mathrm{~mm}$ precipitation compared to the $88 \mathrm{~mm}$ long-term average (figs. 29A, B). January 1993 precipitation was much greater than precipitation for the next 2 wettest months, February and December, of that water year. Although June was typically the driest month, with only $3.8 \mathrm{~mm}$ precipitation (fig. 29A), June precipitation for water year 1993 (45 mm) was about 12 times greater than average. Runoff during water year 1993 was greatest in January $(160 \mathrm{~mm})$, in contrast to the long-term average, for which the greatest average monthly runoff, only $9.8 \mathrm{~mm}$, was in February. 

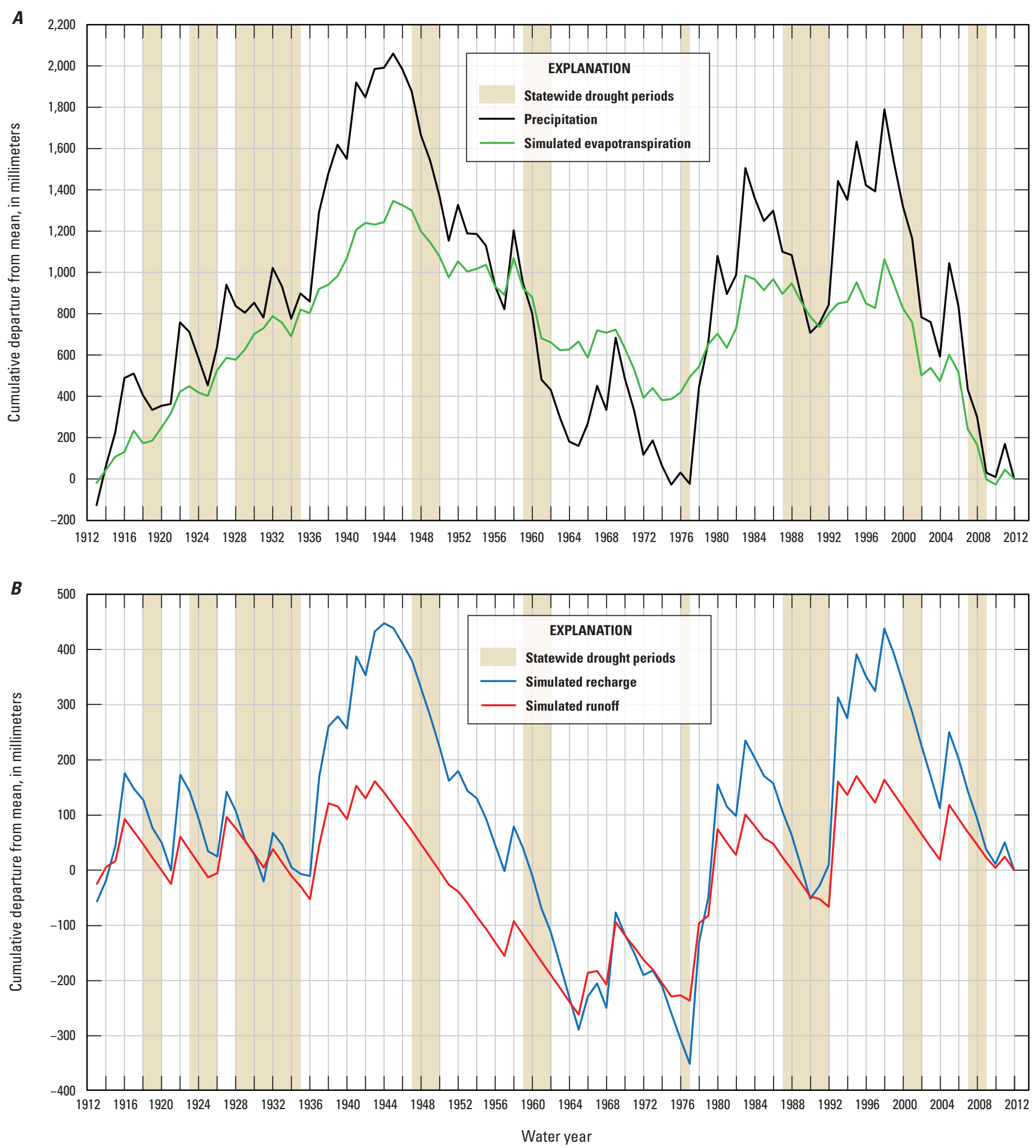

Figure 27. Cumulative departure from the mean using the San Gorgonio Pass watershed model, California, for $A$, estimated precipitation and simulated evapotranspiration; and $B$, simulated recharge and runoff. 


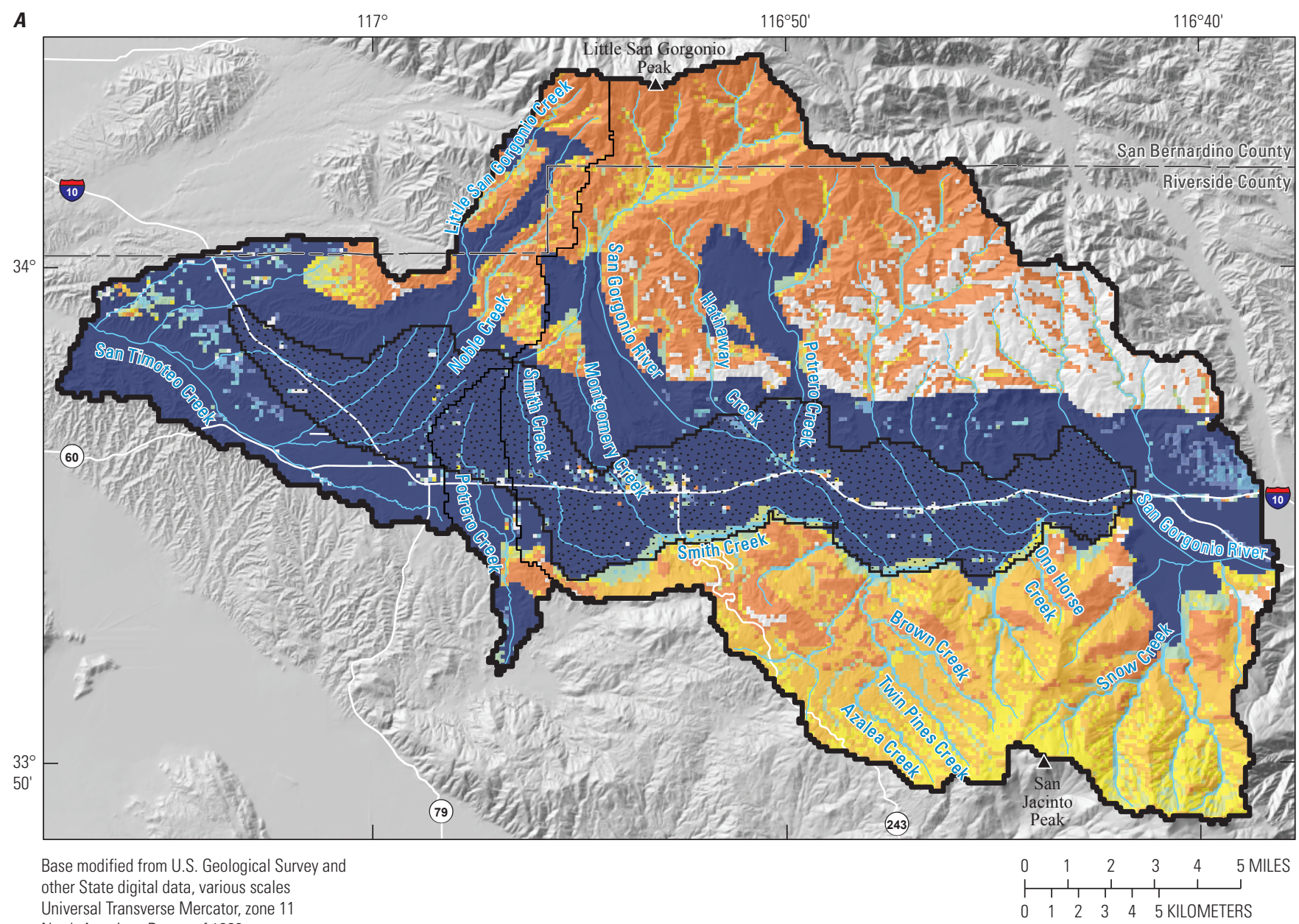

EXPLANATION

Simulated 1993 recharge in millimeters

\begin{tabular}{|l|l|l|}
\hline $0-10$ & $51-100$ \\
\hline $11-20$ & $101-150$ \\
\hline $21-30$ & $151-200$ \\
\hline $31-40$ & $201-250$ \\
\hline 30 & $251-10,324$ \\
\hline
\end{tabular}

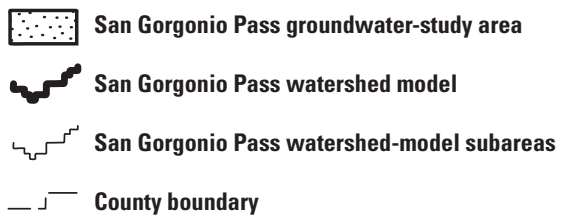

Figure 28. Simulated recharge using the San Gorgonio Pass watershed model, California, for $A$, water year 1993; and $B$, water year 2004. 
B

117

$116^{\circ} 50^{\prime}$

$116^{\circ} 40^{\prime}$

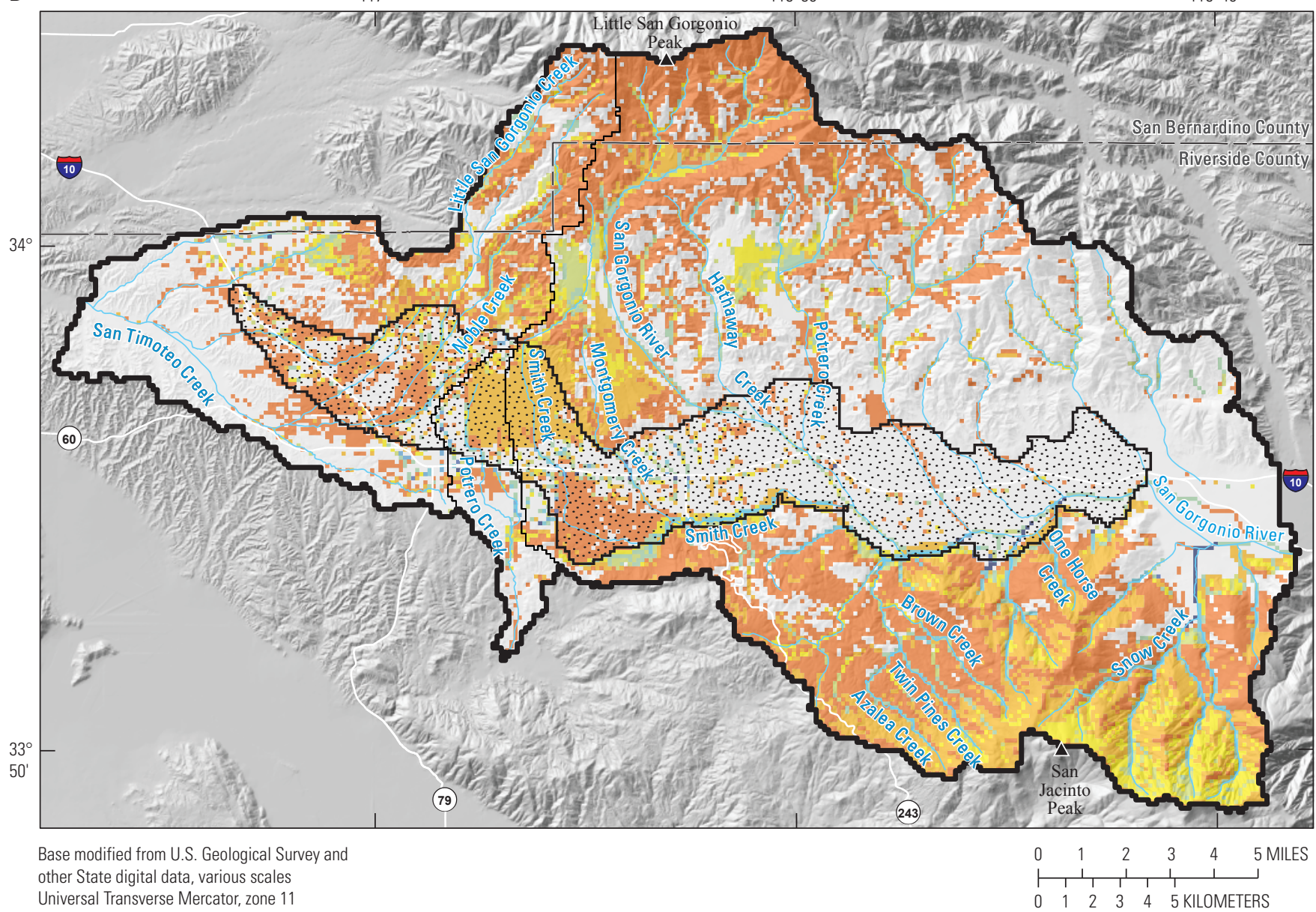

Universal Transverse Mercator, zone 11

EXPLANATION

Simulated 2004 recharge in millimeters

\begin{tabular}{|l|l|l|}
\hline 0 & & $51-100$ \\
\hline 10 & $101-150$ \\
\hline $11-20$ & $151-200$ \\
\hline $21-30$ & \\
\hline 3 & $201-250$ \\
\hline 3 & $251-10,324$ \\
\hline
\end{tabular}

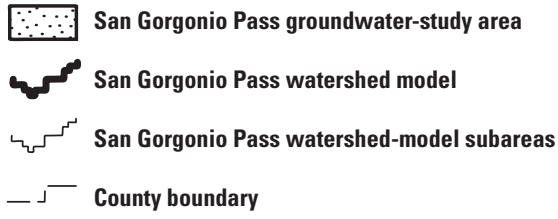

Figure 28. -Continued 
Table 9. Simulated 100-year water budget using the San Gorgonio Pass watershed model, California: results for water year 1993.

[Abbreviations: ha-m, hectare-meters; mm, millimeter; SGPWM, San Gorgonio Pass watershed model]

\begin{tabular}{|c|c|c|c|c|c|c|c|c|}
\hline \multirow{2}{*}{$\begin{array}{c}\begin{array}{c}\text { Results for water } \\
\text { year } 1993\end{array} \\
\text { (a wet water year) } \\
\begin{array}{c}\text { Water budget } \\
\text { component }\end{array}\end{array}$} & \multicolumn{4}{|c|}{ Average depths } & \multicolumn{4}{|c|}{ Total volumes } \\
\hline & \multicolumn{3}{|c|}{ Model subdomains } & $\begin{array}{c}\text { SGPWM } \\
(\mathrm{mm})\end{array}$ & \multicolumn{3}{|c|}{ Model subdomains } & $\begin{array}{c}\text { SGPWM } \\
\text { (ha-m) }\end{array}$ \\
\hline \multicolumn{9}{|c|}{ Inflows } \\
\hline \multicolumn{9}{|c|}{ Outflows } \\
\hline Evapotranspiration & 420 & 461 & 429 & 436 & 888 & 6,606 & 22,486 & 29,979 \\
\hline Recharge & 582 & 532 & 334 & 383 & 1,231 & 7,620 & 17,490 & 26,341 \\
\hline Runoff & 19 & 60 & 313 & 251 & 41 & 862 & 16,397 & 17,301 \\
\hline Root zone & 14 & 16 & 7.6 & 9.4 & 30 & 222 & 397 & 649 \\
\hline Perched zone & 4.9 & 3.7 & 9.7 & 8.3 & 10 & 53 & 506 & 569 \\
\hline Sub-total & 19 & 19 & 17 & 18 & 41 & 275 & 903 & 1,218 \\
\hline
\end{tabular}

Table 10. Simulated 100-year water budget using the San Gorgonio Pass watershed model, California: results for water year 2004.

[Abbreviations: ha-m, hectare-meters; mm, millimeter; SGPWM, San Gorgonio Pass watershed model]

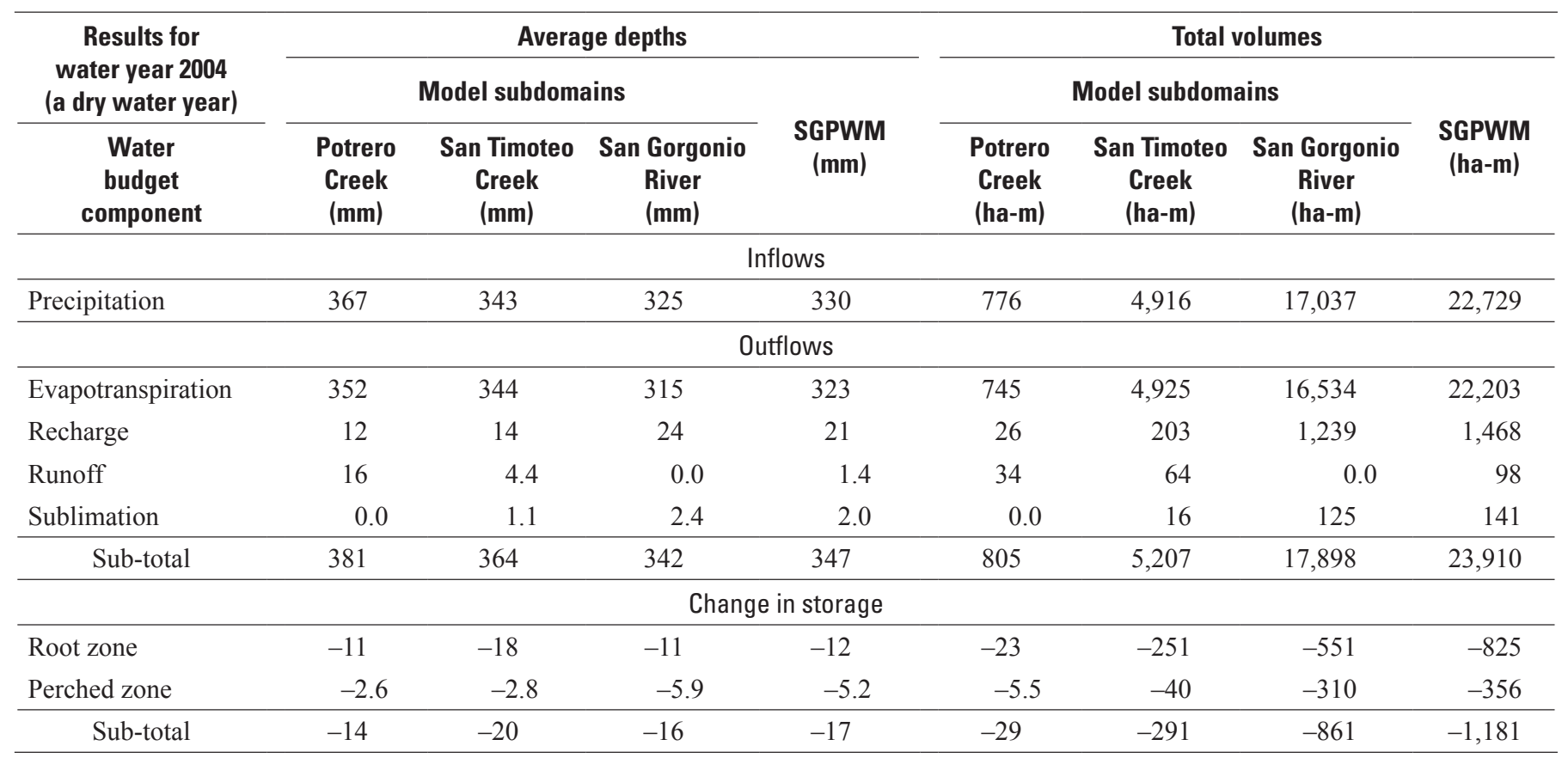



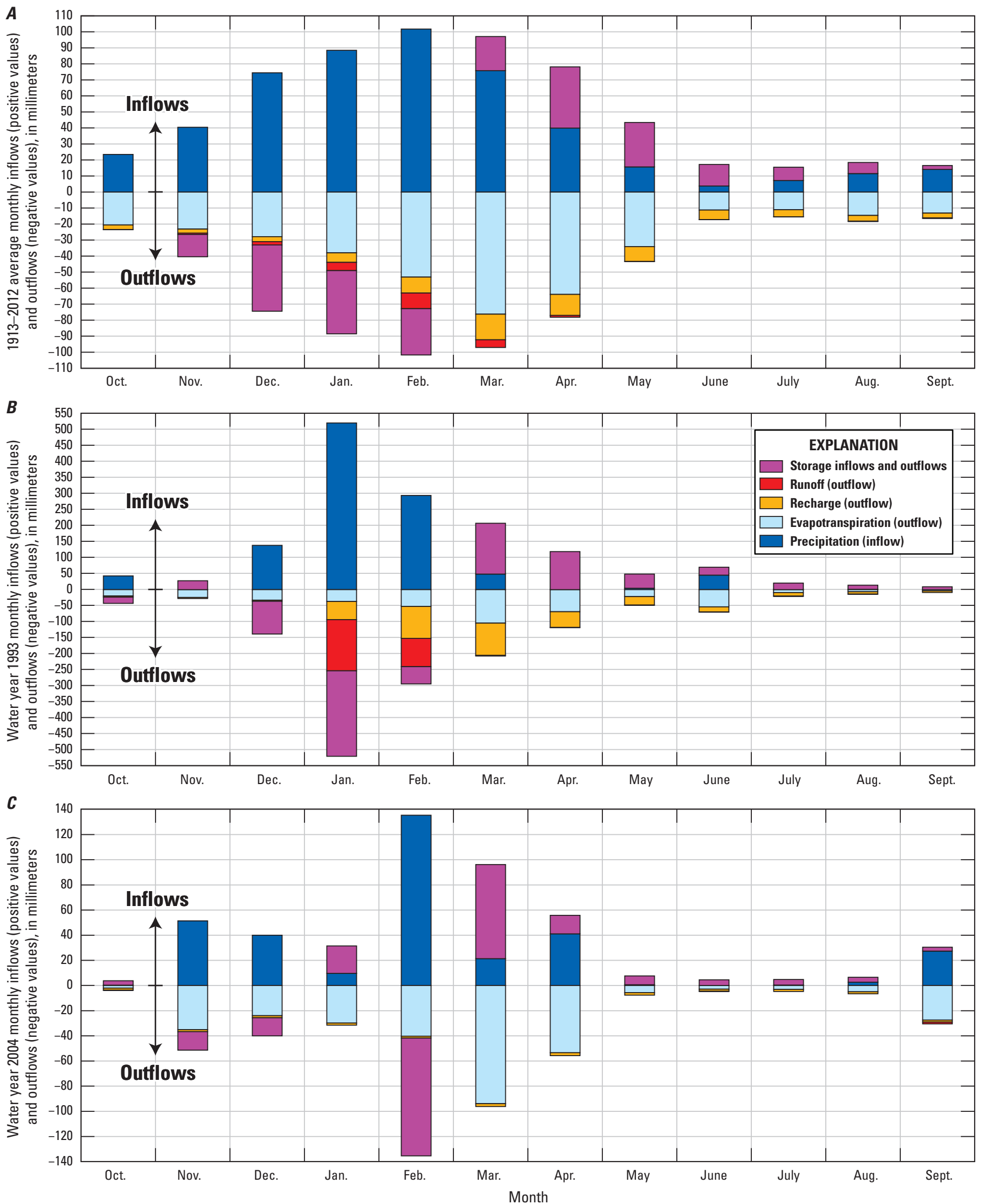

Figure 29. Monthly simulation results for selected components of the water budget using the San Gorgonio Pass watershed model, California: $A$, average monthly results for water years 1913-2012; $B$, monthly results for water year 1993; and $C$, monthly results for water year 2004. 
Monthly simulation results for the drier than average water year 2004, with $330 \mathrm{~mm}$ precipitation, indicated February was the wettest month, with $135 \mathrm{~mm}$ precipitation, which was consistent with the long-term average monthly distribution (figs. 29A, C). November and April, however, were wetter than December, January, and March during 2004, in contrast to the long-term average, where November and April were drier than these months. About 98 percent of the precipitation for water year 2004 was lost to ET. In general, the results for selected water years indicated high variability in monthly recharge and runoff compared to the long-term average monthly values; recharge varied by a factor of about 4 to 5 , and runoff varied by a factor of about 15 to 17 , for wet and dry years compared to the long-term average.

\section{Mountain Front Recharge}

The SGR subdomain of the SGPWM was used to evaluate differences in recharge and runoff between the area of the SGPGSA in the Banning and Cabazon hydrographic areas and in the surrounding surface-water subdrainages upstream of the SGPGSA, including the San Bernardino mountain block to the north and San Jacinto Peak mountain block to the south (fig. 30). A total of 52 surface-water subdrainage areas were represented by using the SGPWM flow-routing network and the location of major stream channels intersecting the SGPGSA boundary. Simulated runoff and recharge for the two mountain block areas are inflows to the SGPGSA and can be used to help define boundary conditions for groundwater-flow models of the SGPGSA.

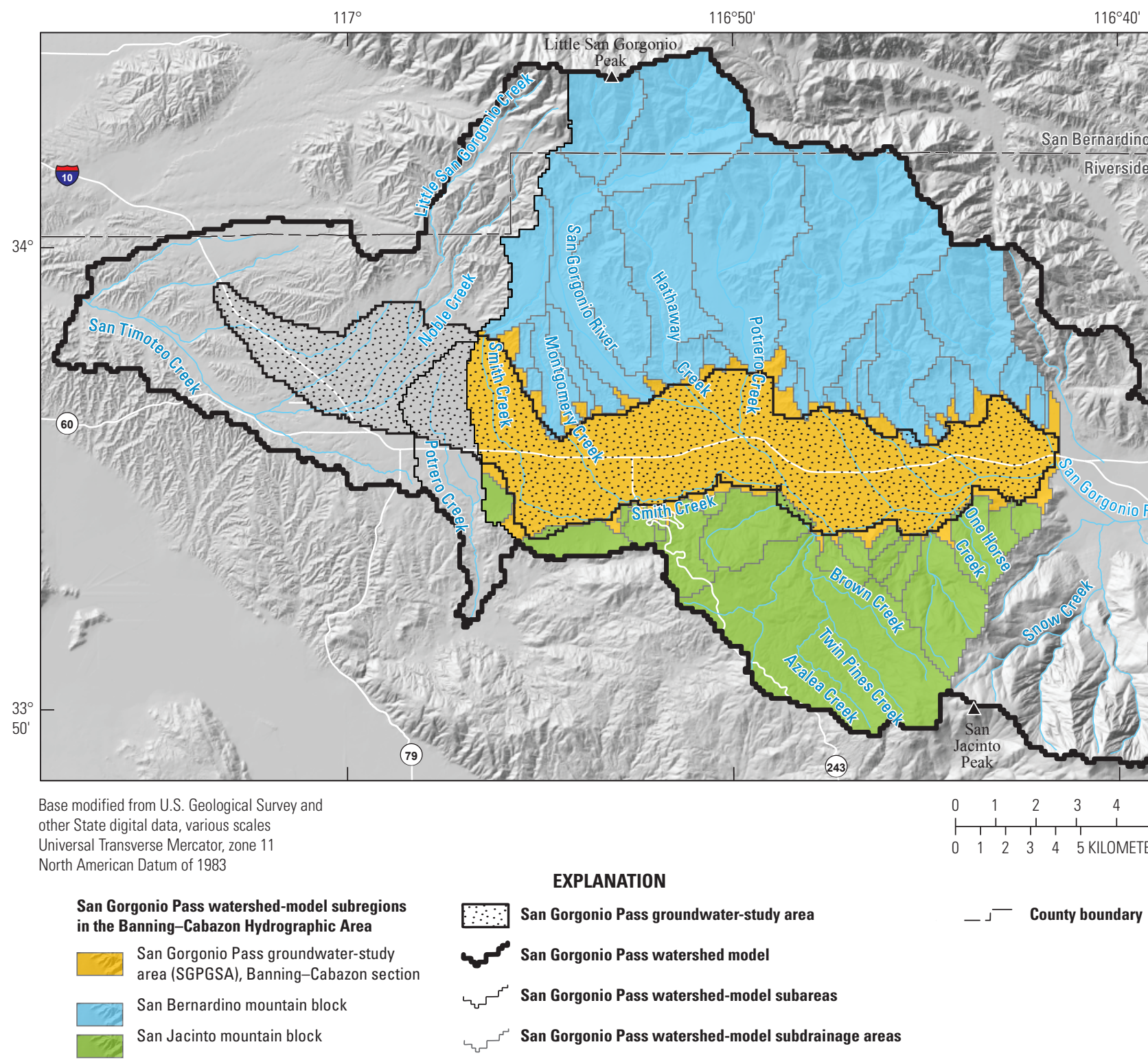

Figure 30. San Bernardino and San Jacinto mountain block areas used to simulate mountain-front recharge for the Banning and Cabazon hydrographic areas of the San Gorgonio Pass groundwater study area, San Gorgonio Pass watershed model, California. 
Comparison of the annual (water year) time series of simulated recharge for the SGPGSA and the two mountain block areas indicated similar annual recharge volumes for the SGPGSA and the San Bernardino mountain block (fig. 31A). The annual results for the SGPGSA and the two mountain block areas were calculated by summing the annual results for all model cells in each area and dividing the sum by the number of cells in each area. Recharge for the SGPGSA and the San Bernardino mountain block had a high degree of annual variability directly correlated to the annual variability in precipitation. Annual recharge varied between 100 and 7,400 hectare-meters for the SGPGSA and between 300 and 6,050 hectare-meters for the San Bernardino mountain block. In contrast, recharge for the San Jacinto mountain block had much less year-to-year variability, and recharge varied between 300 and 700 hectare-meters throughout the 100 -year simulation period. For the wettest years, such as 1993, recharge was greatest for the SGPGSA. In contrast, during dry periods such as water years 2000-04, recharge in both of the mountain block areas was greater than recharge in the SGPGSA. The distribution of recharge changed because during wet years the greater recharge in the SGPGSA and the upper valleys of the San Bernardino mountain block was caused mostly by the infiltration of streamflow, whereas during the dry years recharge was mostly the result of direct infiltration of rainfall and snowmelt in the higher altitudes of the mountains, rather than the infiltration of streamflow.

Similar to the results for recharge, the time series of simulated annual runoff showed very similar results for the SGPGSA and the San Bernardino mountain block areas (fig. $31 B$ ). Unlike the results for annual recharge, simulated annual runoff for the San Jacinto Peak mountain block showed much more year-to-year variability. For most water years, the runoff volume for the San Jacinto Peak mountain block tended to be much less compared to runoff from the other areas.

Average monthly recharge and runoff was calculated for the SGPGSA and the two mountain block areas by summing the monthly results for each month for all cells in each area and dividing by the number of cells in each area and the number of months $(1,200)$. The average monthly results for recharge and runoff indicated very similar seasonal variations for all three areas (fig. 32). Average monthly recharge was greatest during March for all areas (fig. 32A), and average monthly runoff was greatest during February for all areas (fig. 32B). Similar to the annual results, the average monthly recharge results indicated much less variability in seasonal recharge for the San Jacinto Peak mountain block compared to the SGPGSA and the San Bernardino mountain block (figs. $31 A, 32 A$ ). In contrast to the results for recharge, average monthly runoff indicated much more seasonal variability for the San Jacinto Peak mountain block, similar to the variability in runoff for the SGPGSA and the San Bernardino mountain block (fig. 32B).

\section{Effects of Imperviousness}

The effects of imperviousness on runoff and recharge were evaluated by mapping the difference in results between simulations where imperviousness was included (fig. 5) and simulations where imperviousness was set to zero for all cells. The difference in simulated runoff, calculated as the imperviousness-excluded result subtracted from the imperviousness-included result, indicated the increase in runoff expected when impervious surfaces were included in the model (fig. 33). Runoff in the more developed areas increased by as much as 101 to $1,000 \mathrm{~mm} / \mathrm{yr}\left(7.1 \mathrm{E}-5\right.$ to $\left.7.1 \mathrm{E}-4 \mathrm{~m}^{3} / \mathrm{s}\right)$. The increased runoff was routed to the main channels, increasing streamflow in the San Gorgonio River and San Timoteo Creek by 1,001 to $2,830 \mathrm{~mm} / \mathrm{yr}\left(7.1 \mathrm{E}-4 \mathrm{~m}^{3} / \mathrm{s}\right.$ to $\left.2.0 \mathrm{E}-3 \mathrm{~m}^{3} / \mathrm{s}\right)$. Imperviousness associated with roads in the mountain block areas, upstream of the developed areas, also caused minor increases in average annual runoff of 2.1 to $50 \mathrm{~mm} / \mathrm{yr}$ (1.5E-6 to $3.6 \mathrm{E}-5 \mathrm{~m}^{3} / \mathrm{s}$ ).

Unlike runoff, the difference in simulated recharge indicated both decreases and increases in recharge in response to the inclusion of impervious areas in the SGPWM (fig. 34). Locations with a high percentage of imperviousness had decreases in recharge as a result of the decreased infiltration. Decreases in recharge were as much as -126 to $-50 \mathrm{~mm} / \mathrm{yr}$ for cells in the urban centers and along the main transportation corridor. Adjacent to and directly downstream of these cells, recharge was increased by as much as 51 to $1,178 \mathrm{~mm} / \mathrm{yr}$ because of the increased inflow of runoff from the impervious areas. The basin-wide average recharge was $78 \mathrm{~mm} / \mathrm{yr}$ when imperviousness was excluded and was $80 \mathrm{~mm} / \mathrm{yr}$ when imperviousness was included. The slight increase indicated the effect of increased runoff on recharge, but the difference was not considered important on a basin-wide scale.

\section{Comparison of Models}

The simulated long-term average recharge was compared to results from the Rewis model (fig. 35). Comparisons were made by using GIS to upscale the $30-\mathrm{m}$ grid from the Rewis model to the coarser 150-m grid that was used in the SGPWM and, then, subtracting the results from both models. The comparisons were limited to the smaller area of the Rewis model, which covers the western part of the SGPWM.

Simulated recharge for the two models were similar in terms of the basin-wide average, however, as indicated in figure 35 , large positive and negative differences (greater than $25 \mathrm{~mm}$ and less than $-25 \mathrm{~mm}$ ) were calculated for many locations. The average long-term recharge for the previous model, simulated for water years $1930-2001$ by using a 30-m grid, was about $86 \mathrm{~mm} / \mathrm{yr}$ (Rewis and others, 2006). Average recharge for the up-scaled Rewis model was $82 \mathrm{~mm} / \mathrm{yr}$. The result for the SGPWM was $90 \mathrm{~mm} / \mathrm{yr}$, which was less than a 10-percent increase. The comparison indicated that upscaling the Rewis model results did affect model results, but not by much. 

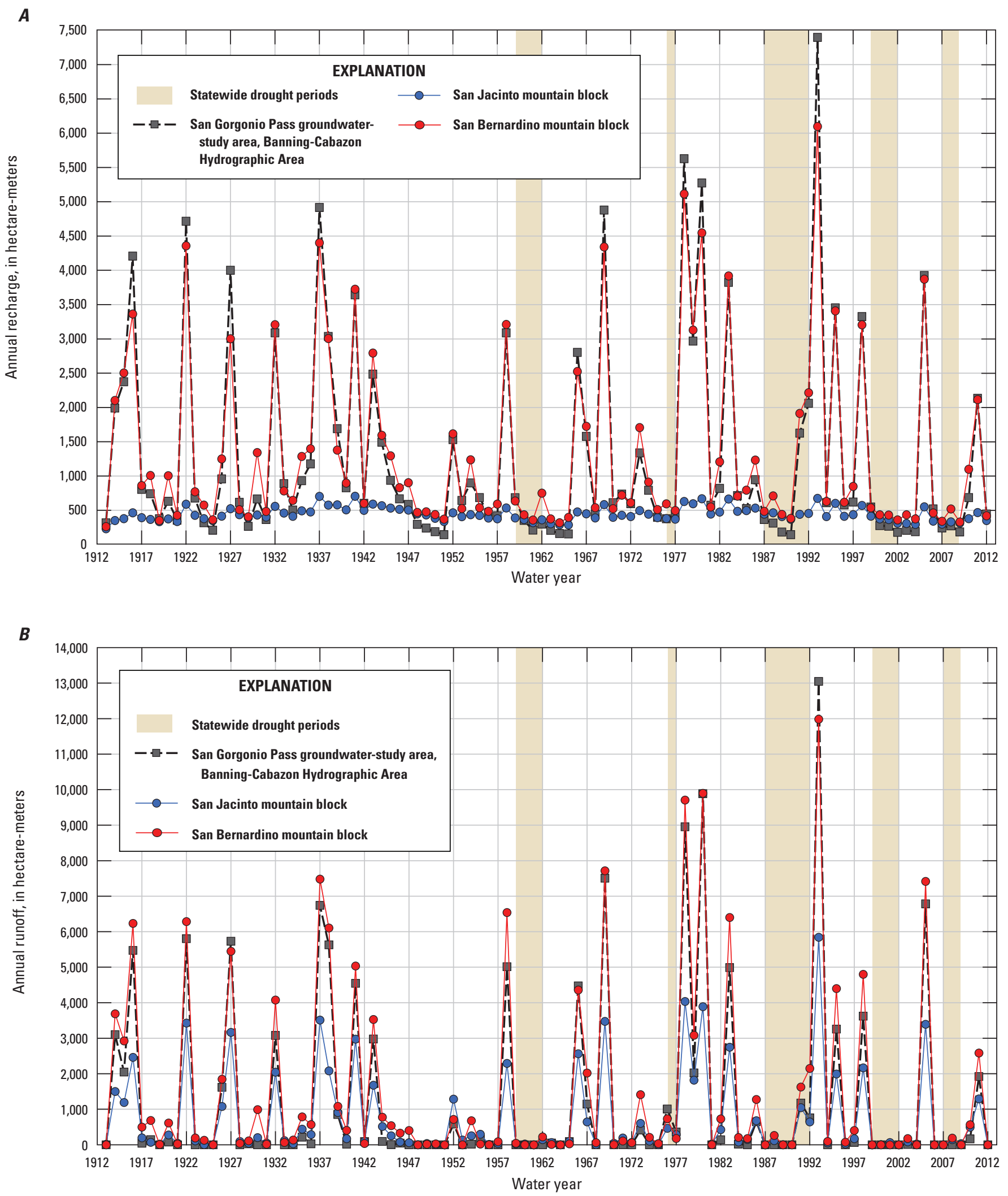

Figure 31. Annual simulation results for the San Gorgornio Pass groundwater study area (SGPGSA) and the San Bernardino and San Jacinto mountain blocks using the San Gorgonio Pass watershed model, California: $A$, recharge; and $B$, runoff. 

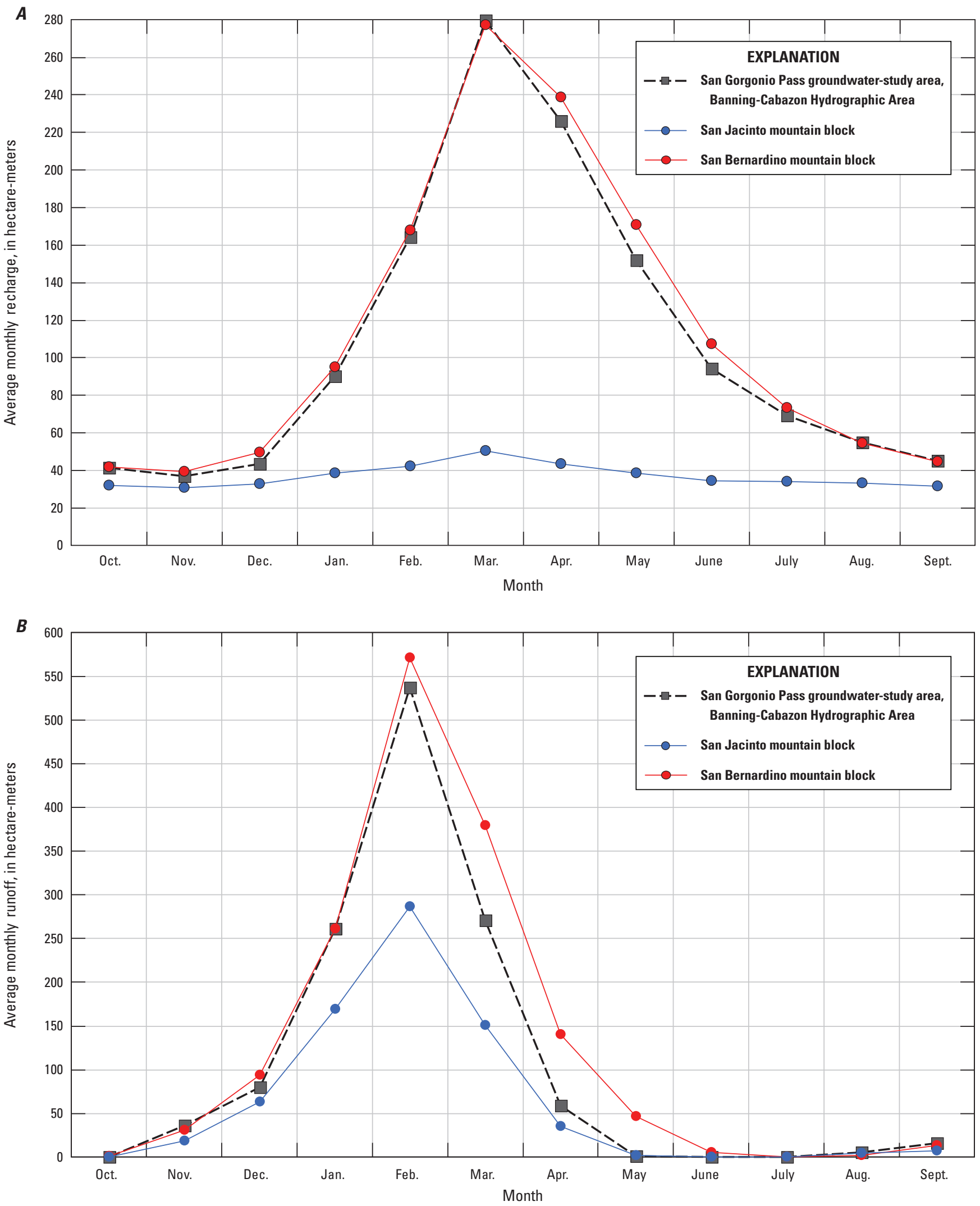

Figure 32. Average monthly simulation results for water years 1913 to 2012 for the San Gorgornio Pass groundwater study area (SGPGSA) and the San Bernardino and San Jacinto mountain blocks using the San Gorgonio Pass watershed model, California: $A$, recharge; and $B$, runoff. 


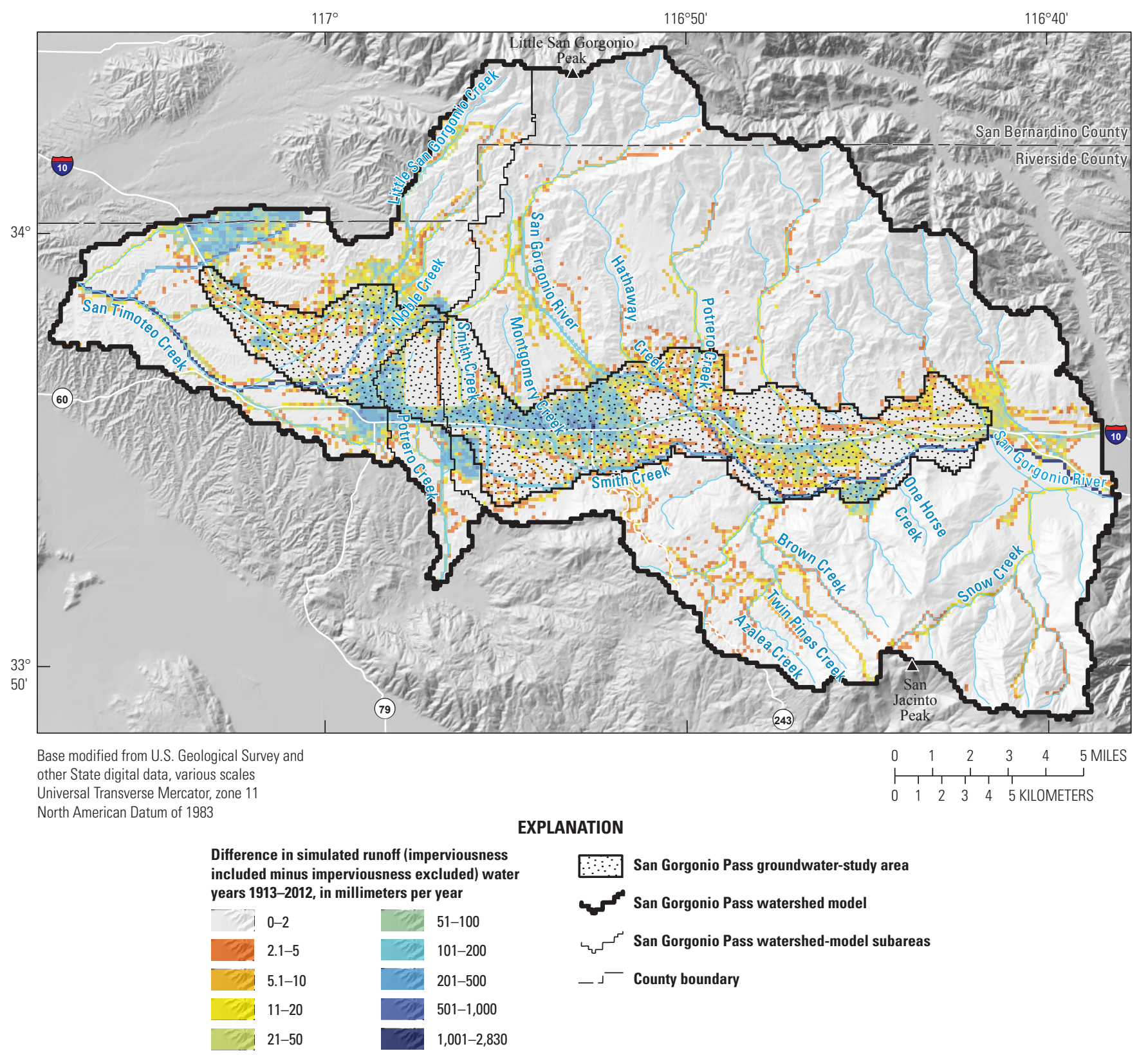

Figure 33. Difference in simulated runoff for imperviousness-included minus imperviousness-excluded simulations using the San Gorgonio Pass watershed model, California. 


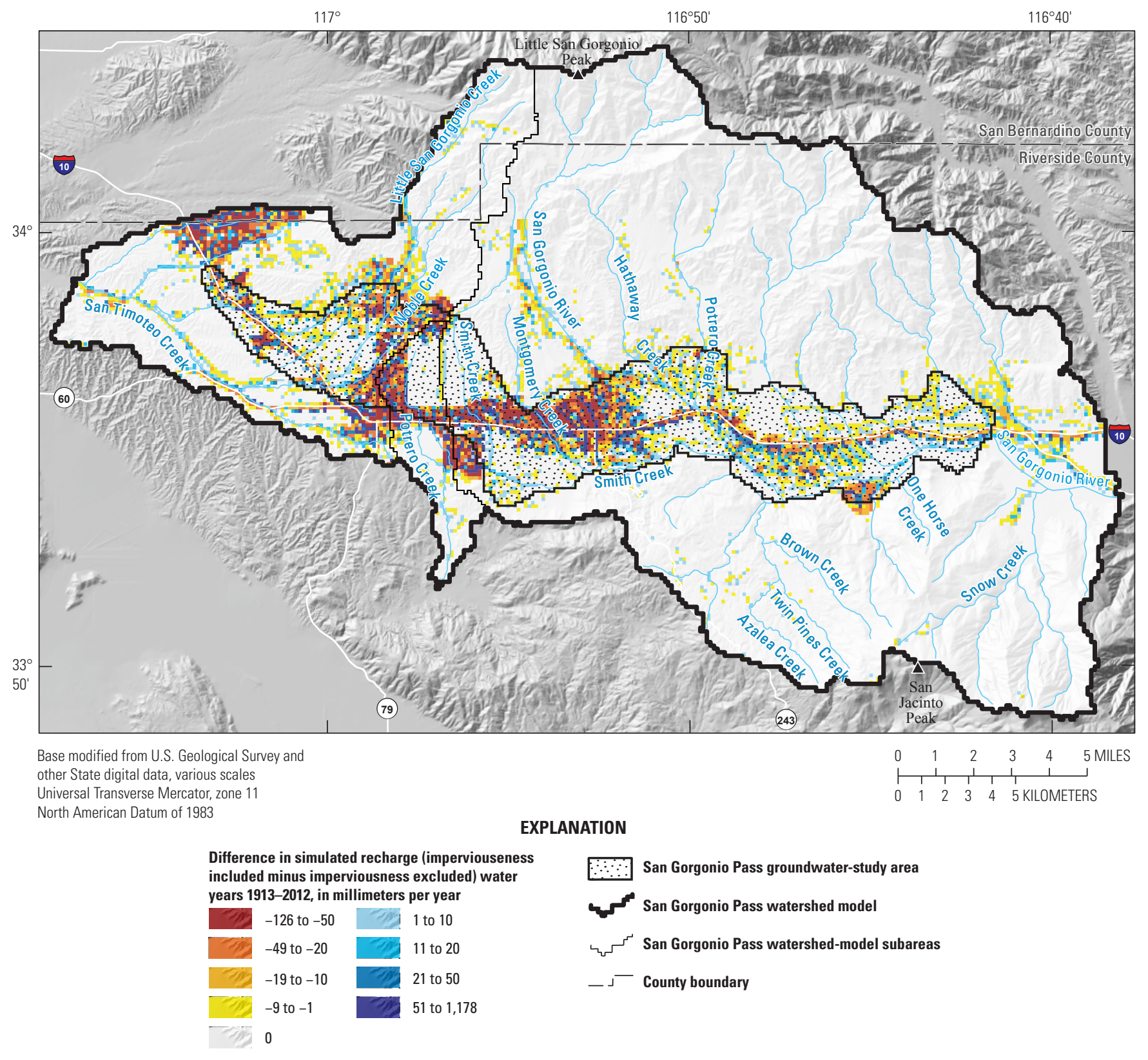

Figure 34. Difference in simulated recharge for imperviousness-included minus imperviousness-excluded simulations using the San Gorgonio Pass watershed model, California. 


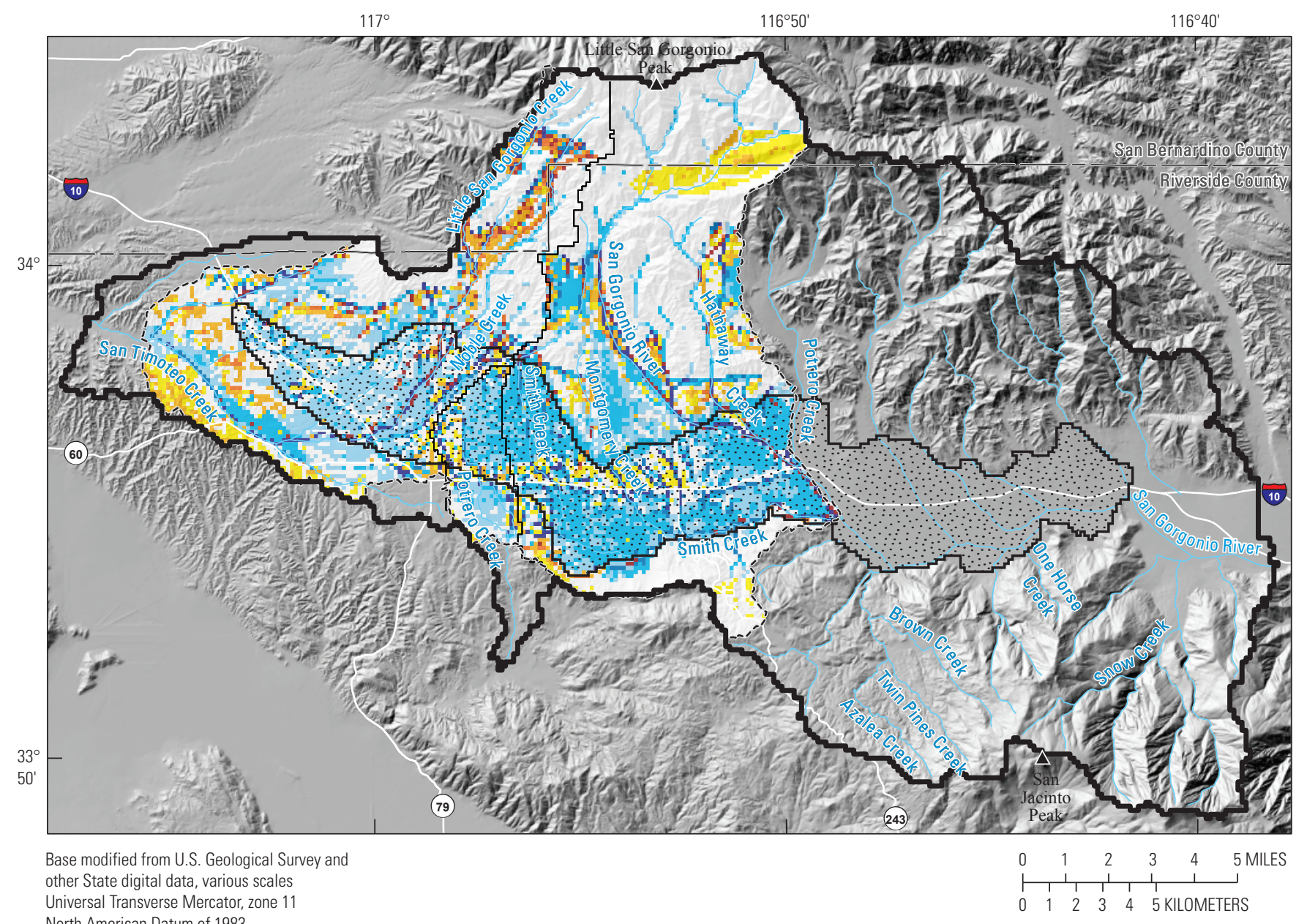

Universal Transverse Mercator, zone 11 North American Datum of 1983

\section{EXPLANATION}

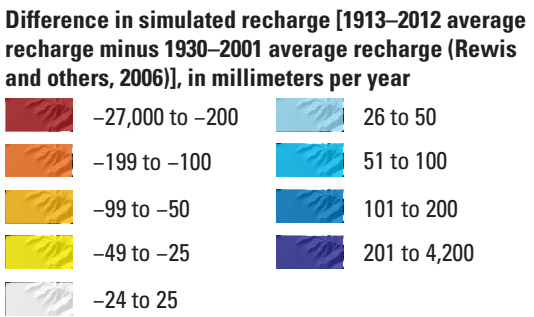

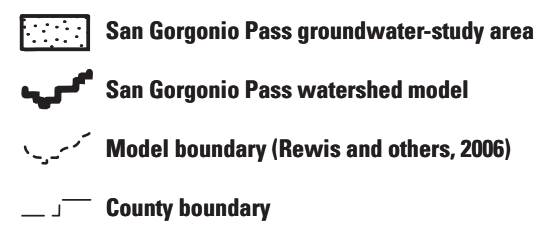

$-\lrcorner$ County boundary

Figure 35. Difference in simulated recharge results from the updated model minus results from the previous model using the San Gorgonio Pass watershed model, California.

On a cell-by-cell basis, there were large differences in recharge between the two models. The greatest differences were in areas along rivers and creeks because the locations of streamlines were not identical for the two models. The differences in the streamline locations resulted from the combined effects of upscaling and differences in the flow-routing layout for the two models. Other factors causing differences in simulated recharge between the two models were (1) the effect of seepage flow by using the updated model, (2) the differences in the climate inputs between the two models, and (3) the differences in the simulation periods used to calculate the long-term average recharge rates. The models were most similar in the upland areas of the San Bernardino Mountains, as indicated by the large area where differences in recharge were between -24 and $25 \mathrm{~mm} / \mathrm{yr}$. Areas with large negative differences (less than $-24 \mathrm{~mm} / \mathrm{yr}$ ) were in the main drainages of Noble Creek and the upper San Gorgonio River drainage. These reductions in recharge, where recharge simulated by the SGPWM was less than recharge simulated by the Rewis model, were caused by the effect of the seepage-flow component included in the SGPWM.

Additional comparisons were made by using annual results for water years 1930-2001, the period simulated by the Rewis model. Seven model components were compared: precipitation, air temperature, snowfall, PET, ET, recharge, and runoff. The t-test was used to identify significant differences in annual results between the models at a 95-percent level of confidence, and the kensen test (an R program application 
of the Mann-Kendall test for trend significance) was used to identify trends in the annual time series (http://www.inside-r. org/node/96907; Slack and others, 2003).

The average annual precipitation was about the same in both models, with no significant difference indicated by the t-test and no significant trend indicated by the kensen test of the annual time series (fig. 36A). Differences in annual precipitation were slight for most water years, with larger differences for water years 1932, 1937, 1941, 1943, 1944, and 1946. Similar to precipitation, differences in annual air temperature were not found to be significant at the 95-percent confidence level, with a long-term mean temperature of $14.5^{\circ} \mathrm{C}$ for the SGPWM and of $14.7^{\circ} \mathrm{C}$ for the Rewis model (fig. 36B). The k test indicated no significant trend in air temperature for either model for the 72-year period. Results for annual snowfall and PET indicated greater relative differences between the two models (figs. 36C-D). Annual average snowfall for the SGPWM and the Rewis model was $51 \mathrm{~mm} / \mathrm{yr}$ and $30 \mathrm{~mm} / \mathrm{yr}$, respectively, and annual PET was 1,620 and 1,440 mm/yr, respectively. The $\mathrm{t}$-tests both for snowfall and PET indicated a significant difference between the two models, and the kensen test indicated significant trends for decreasing snowfall and increasing PET in both models for the 72-year period. In general, the yearto-year variability for all components was similar for both models, with a good match in the high and low annual values.

Results for model components ET and recharge were similar for the two models, with a close match in the year-toyear variability in the annual time series (figs. 36E, $F$ ). The long-term average ET for the SGPWM was $390 \mathrm{~mm} / \mathrm{yr}$, compared to $391 \mathrm{~mm} / \mathrm{yr}$ for the Rewis model, and the long-term average recharge for the SGPWM was $83 \mathrm{~mm} / \mathrm{yr}$, compared to $86 \mathrm{~mm} / \mathrm{yr}$ for the Rewis model. Both models indicated an increase in the year-to-year variability in recharge in the second half of the simulation period, with the three highest annual recharge amounts after water year 1977. The t-test results for ET and recharge indicated no significant difference between the models at the 95-percent confidence level, and the kensen test indicated no significant trends in the annual time series for either ET or recharge.

Results for simulated annual runoff indicated a difference between the models (fig. 36G). The 72-year average runoff for the SGPWM was $25 \mathrm{~mm} / \mathrm{yr}$, compared to $16 \mathrm{~mm} / \mathrm{yr}$ for the Rewis model. Peak annual runoff was more for the SGPWM model than for the Rewis model. Maximum runoff for both models was during water year 1993; however, the $250 \mathrm{~mm}$ runoff for the SGPWM was much greater than the $140 \mathrm{~mm}$ for the Rewis model. Although the relative differences in runoff were greater than the relative differences in ET and recharge, the t-test did not indicate a significant difference between the two models, and the kensen test did not indicate a significant trend in the annual time series.

Generally, results for the two models were quite consistent in terms of matching wet and dry periods. Average precipitation for DWR drought years was $408 \mathrm{~mm} / \mathrm{yr}$ for the SGPWM, compared to $404 \mathrm{~mm} / \mathrm{yr}$ for the Rewis model. For both models, average snowfall and PET for the DWR drought periods were similar to the 72-year average PET and snowfall. Recharge and runoff, however, showed large differences between averages for DWR drought years and the 72-year averages. For the SGPWM, the average recharge rate for the DWR drought years was $47 \mathrm{~mm} / \mathrm{yr}$, or about 57 percent of the 72-year average recharge rate. For the Rewis model, the average recharge rate for the DWR drought years was $33 \mathrm{~mm} / \mathrm{yr}$, or about 39 percent of the 72-year average rate. Runoff was most sensitive to the drought years: for the SGPWM, average runoff during the drought years was $5.8 \mathrm{~mm} / \mathrm{yr}$ (about 23 percent of the 72-year average), and for the Rewis model, the average runoff for drought years was $3.5 \mathrm{~mm} / \mathrm{yr}$ (about 22 percent of the 72-year average).

\section{Model Limitations}

The SGPWM presented in this study is an expanded and updated version of a previous model calibrated to streamflow records at a single streamgage site (LSGC). With the updated model, comparisons of simulated to measured streamflow were made by using daily mean discharge records from five USGS streamgages. The comparison between simulated and observed streamflow indicated that the fit to measured streamflow at streamgage LSGC was generally consistent with the previous calibrated model presented in Rewis and others (2006). The comparison at the four additional streamgages indicated a satisfactory result at streamgages STCR, SCWW and TCNP. A poor fit was obtained at streamgage CCCT, however.

Model calibration, the process of adjusting model parameters to improve the match between simulated and observed streamflow at the five streamgages, was only done on a limited basis. As discussed in the "Model Calibration" section, changes in model parameters that would result in an improvement in the NSME statistic for one gage would simultaneously cause deterioration in the NSME for another gage because the parameter adjustments were made consistently across the entire model domain by using the mapped basin properties (topography, land-cover, soils, and geology). It was concluded that in order to improve NSME values for all gages, a more rigorous simulation of streamflow (for example, by using an hourly time step and numerically simulating streamflow, rather than by using simple routing), as well as a more rigorous simulation of snow accumulation and snowmelt, would likely be needed.

A major limitation in the SGPWM simulated streamflow is that daily streamflow is based on a daily routing algorithm that assumed episodic streamflows with durations less than 24 hours. All simulated streamflow either discharged from the drainage basin or infiltrated to the root zone at the end of each day. The effect of the simplified 1-day routing for streamflow is that there was a tendency to overestimate the hydrograph peak and underestimate the trailing limb of the hydrograph, which generally represents a combination of delayed runoff, interflow, and baseflow contributions to total streamflow. 

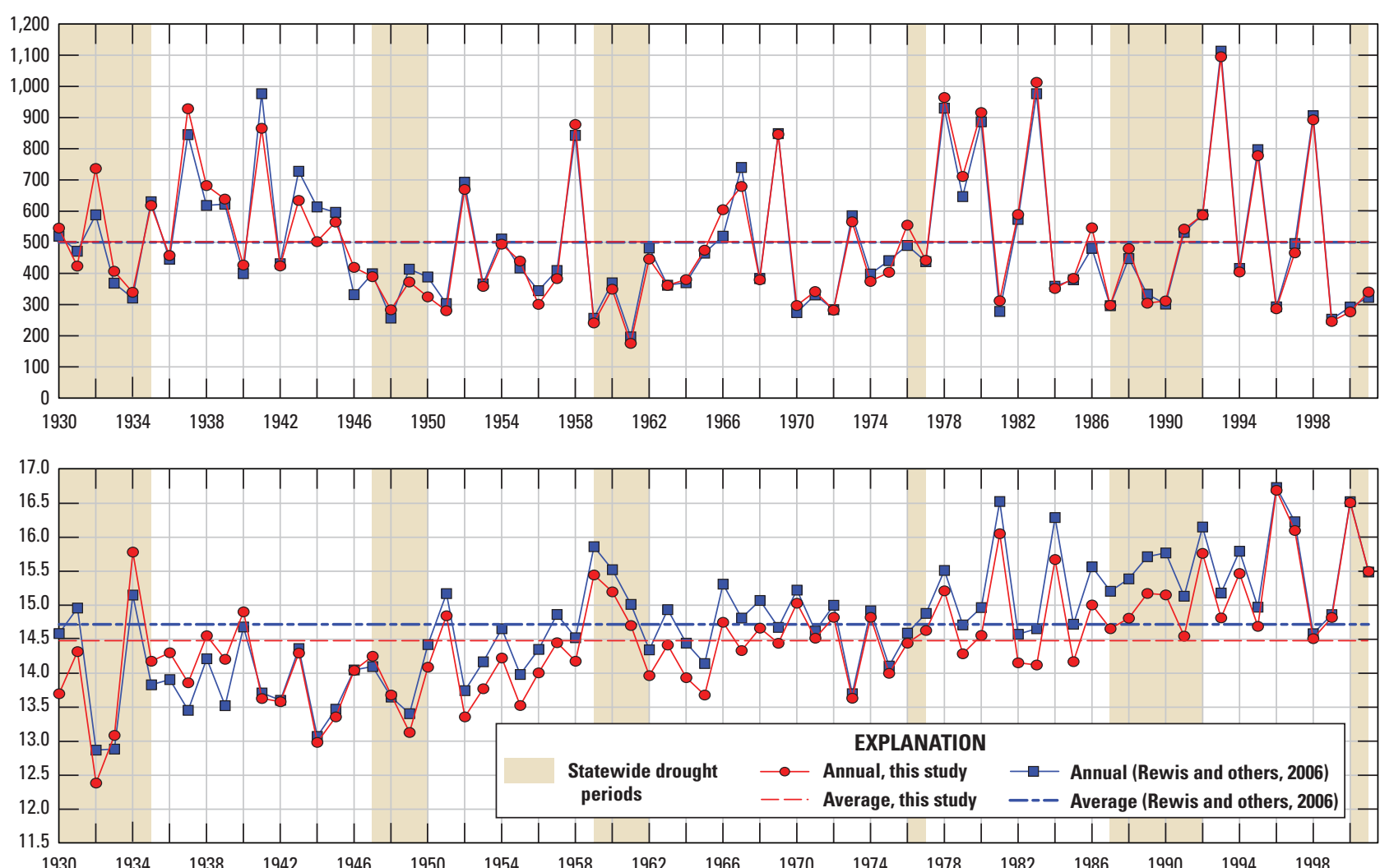

C

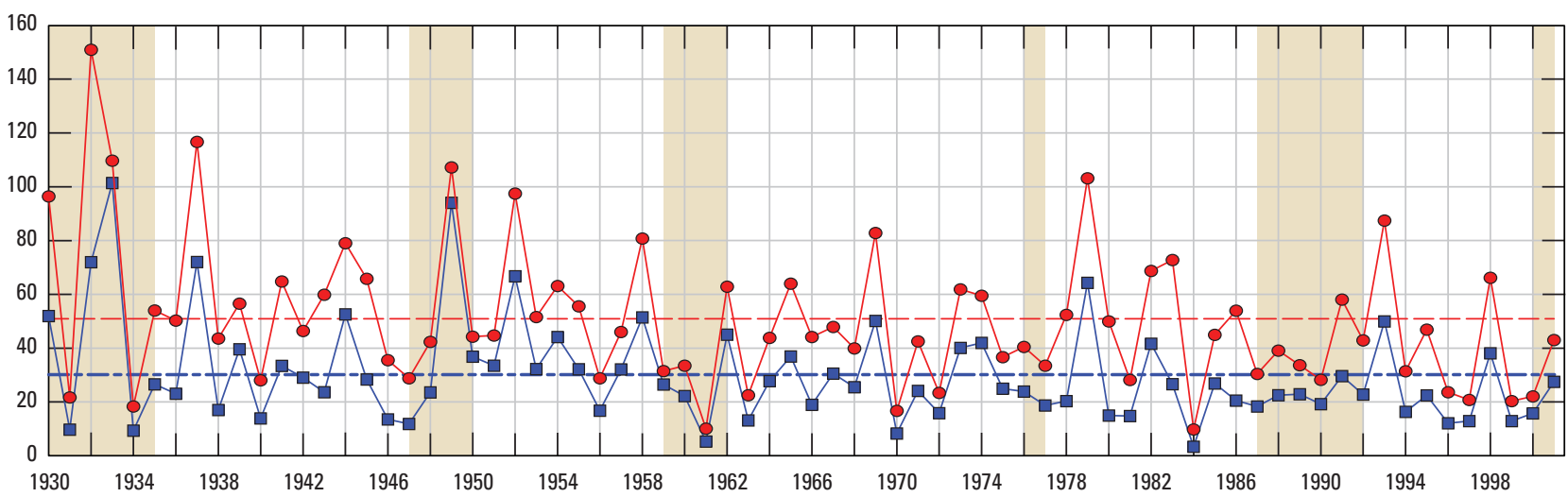

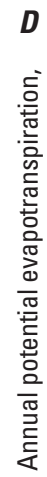

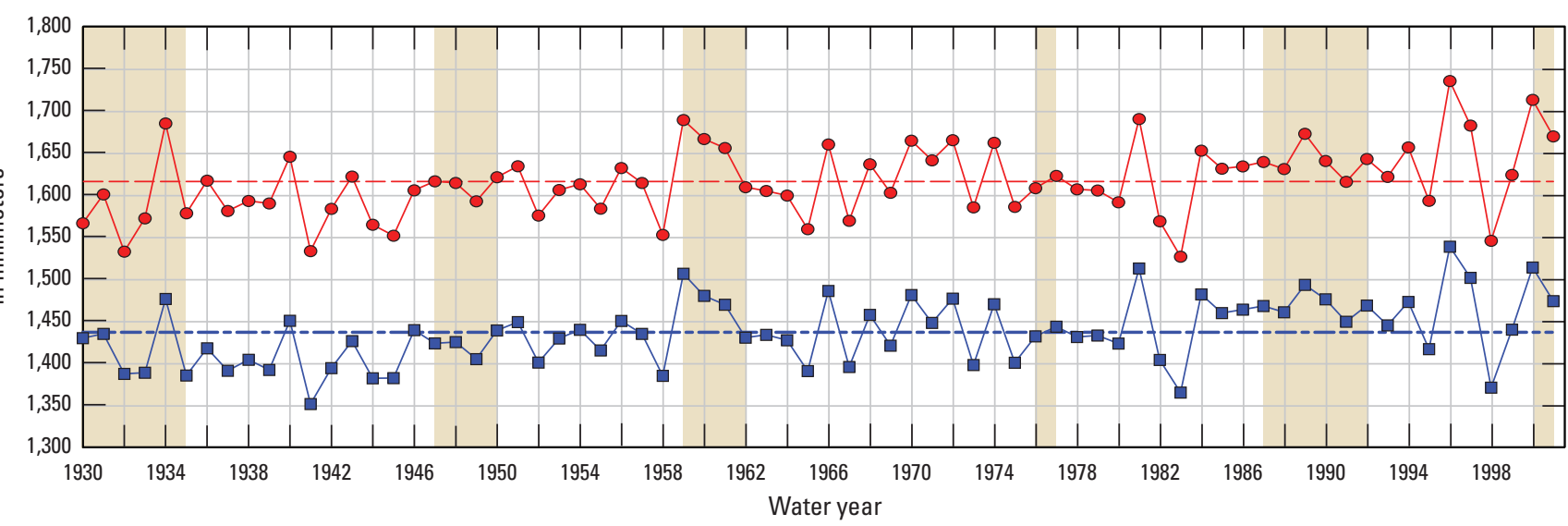

Figure 36. Comparison of annual results for updated and previous models, water years 1930-2001, using the San Gorgonio Pass watershed model, California: $A$, estimated precipitation; $B$, estimated air temperature; $C$, simulated snowfall; $D$, simulated potential evapotranspiration (PET); $E$, simulated evapotranspiration (ET); $F$, simulated recharge; and $G$, simulated runoff. 

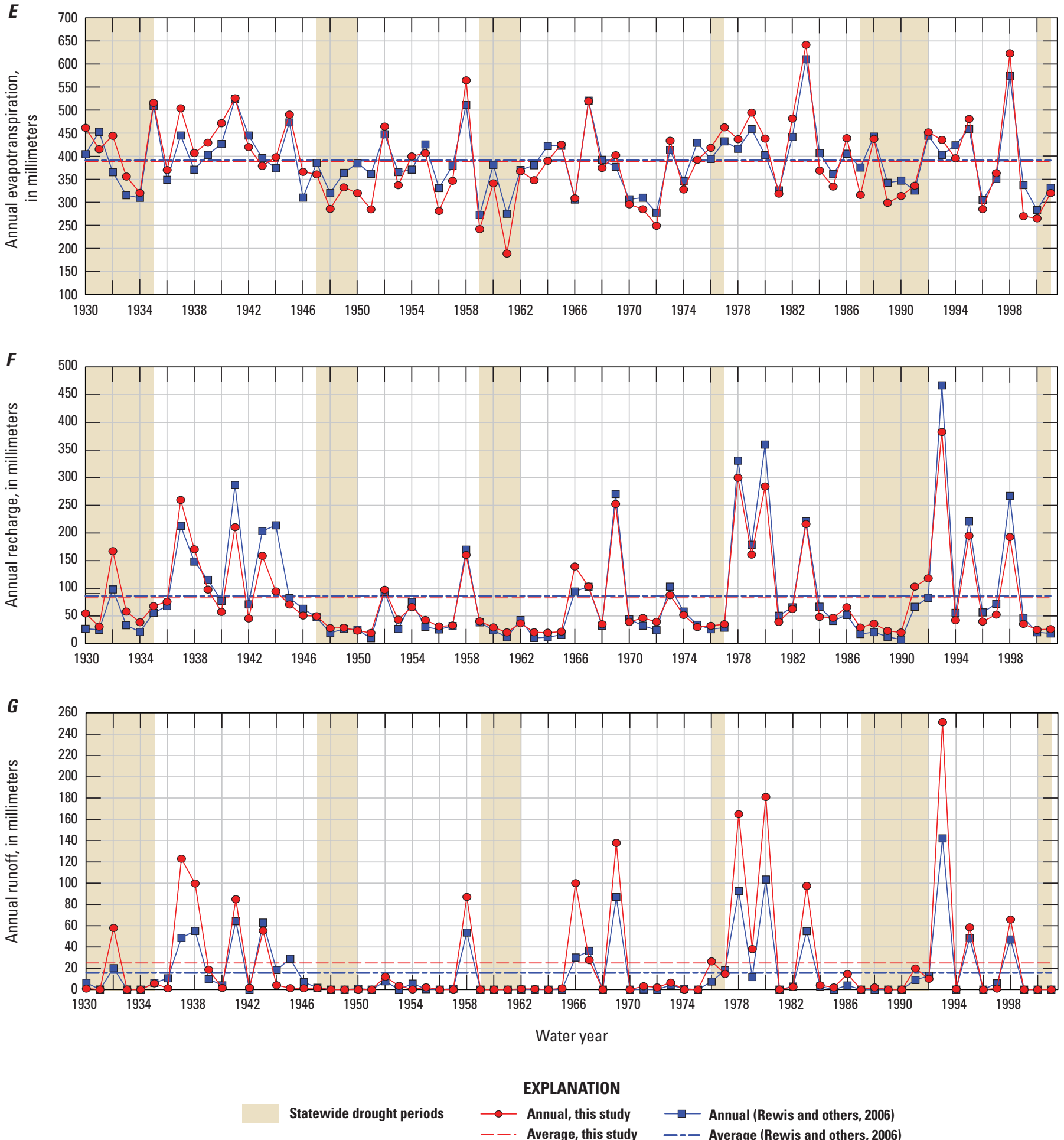

Figure 36. - Continued 
An additional limitation of the SGPWM is that dispersive or divergent streamflow, which can be an important characteristic of streamflow and overland flow across alluvial fans and basins with braided channels, is not represented in the surfacewater flow-routing algorithm. With INFILv3, all surface-water flow is simulated as convergent streamflow, and this could result in an overestimation of runoff in some parts of the study area, especially along the larger channels on alluvial fans and across the transition from steeper channels in the more rugged upland terrain to the more gently sloping, open area of alluvial fans.

Groundwater baseflow is not directly simulated by the SGPWM. Baseflow is only partially represented by the seepage-flow component of the model. The simulation of seepage flow is intended for representing springs and seeps originating from shallow flow paths in rugged mountainous terrain. Seepage flow is not intended to represent spring discharge from deep groundwater aquifers.

Storm runoff is modeled as a cascading flow process in the SGPWM. For a given model cell, surface-water runoff is distributed to the area of the downstream cell as a uniform inflow depth. All runoff generated for a daily time step is routed to the point of surface-water discharge for the three model domains (SGR, STC, PTC). This method does not account for delays in outflow caused by channel storage.

The physical characteristics of the watersheds defined in the SGPWM are static; they do not change with time. Changes in land use and land cover caused by factors such as urbanization and wildfires can cause noticeable changes through time in imperviousness, vegetation, land cover characteristics, and stream channel characteristics that are not represented by the model.

Snow is an important component of the hydrologic system at higher altitudes in the San Bernardino and San Jacinto Mountains. Testing results indicated high uncertainty in the simulation of snowfall and snowmelt in the current SGPWM configuration because it is sensitive to small changes in air temperature. In the SGPWM, snow was simulated only when the average daily air temperature was $0{ }^{\circ} \mathrm{C}$ or less. In actuality, meaningful snow amounts can accumulate during storms when the average recorded air temperature is greater than $0{ }^{\circ} \mathrm{C}$. Also uncertainty in the spatial distribution of precipitation as a result of a sparsity of climate stations could limit the calibration of precipitation-runoff models for this study area. Additional model calibration based on a comparison of simulated snow cover and satellite data could be used to improve the simulation of recharge and runoff for the higher altitudes, where snowfall and snowmelt become important.

The resolution of the state-wide geology map (Jennings, 1977) available to estimate soil depth was considered poor for the scale of the study area (the resolution of the geology map is 1:700,000 scale). Higher resolution maps were available for the SGPGSA, but these did not cover the higher altitudes of the mountain blocks. The state-wide map was used for consistency. This caused some discrepancy in the boundary between locations in valleys with thick soils (as defined by alluvium) and thin soils in rugged upland areas (as defined by consolidated bedrock), however, especially along the northern boundary of the SGPGSA. The resolution of the STATSGO soils map used to develop many of the parameters for the rootzone layers also was low. In general, the STATSGO data are applied to more regional-scale state-wide or national studies. Unfortunately, higher resolution soils data (for example, Soil Survey Geographic data, or SSURGO) for the complete area of the SGPWM were not available at the time of this study.

\section{Summary and Conclusions}

A daily rainfall-runoff model for the San Gorgonio Pass watershed, referred to in this study as the San Gorgonio Pass watershed model (SGPWM), was used to estimate transient natural recharge for the San Gorgonio Pass groundwater study area (SGPGSA). The SGPWM includes the area of the SGPGSA as well as surrounding watersheds adjacent to and outside of the SGPGSA that have the potential to contribute surface-water inflows and mountain-front recharge (fig. 1). The SGPWM was developed by using the INFILv3 code, which was used in a previous study (Rewis and others, 2006) to develop recharge estimates in the western part of the SGPGSA that included the Beaumont and Banning Hydrographic Subareas (HSAs). Natural recharge simulated by the SGPWM includes aerially distributed recharge resulting from the in-place infiltration of rainfall and snowmelt and also recharge from the infiltration of runoff and seepage from upstream areas.

A primary advantage of the application of the SGPWM for recharge estimation is that the effect of climate on recharge is simulated deterministically. Variations in recharge and runoff in response to the spatial and temporal variability of climate and the spatial variability of watershed characteristics are accounted for by using a daily time step and a 150-meter (m) gridded discretization of the model domain. Daily climate data obtained from a regional network of monitoring sites, along with a Parameter-elevation Regressions on Independent Slopes Model (PRISM) average monthly precipitation, were used to develop the climate inputs for the SGPWM. Geographic Information System (GIS) data defining land use, land cover, soils, vegetation, and surficial geology were used as input for defining grid-cell parameters representing the physical characteristics of the SGPWM.

Streamflow simulated by using the SGPWM was compared to available records of streamflow at two U.S. Geological Survey (USGS) streamgages in the SGPWM and three USGS streamgages next to the SGPWM (fig. 16). In terms of the Nash Sutcliffe model efficiency (NSME) index, simulated streamflow provided an acceptable match to three of the annual streamflow records and two of the monthly streamflow records. In terms of the percent average estimation error (PAEE), simulated streamflow provided an acceptable fit 
to three of the five streamflow records. A major challenge in simulating streamflow in this study area is that streamflow was intermittent and was sensitive to hourly precipitation rates, in terms of the hourly precipitation intensity exceeding the infiltration capacity of the ground surface. The hourly precipitation rates are not directly accounted for by using the daily time step applied with the SGPWM. In addition, considerable model uncertainty exists in the simulation of precipitation as snow and subsequent snowmelt, because of uncertainty in spatially interpolated air temperature. The uncertainty in snowfall and snowmelt contributed to limitations in model calibration because small differences in air temperature can have a large effect on snowfall and snowmelt, and this can a have a large effect on the magnitude and timing of runoff.

The SGPWM was used to analyze the spatial and temporal distribution of simulated water-budget components for water years 1913-2012. The 100-year time-averaged results indicate that 78 percent of the basin-wide average precipitation of 496 millimeters per year ( $\mathrm{mm} / \mathrm{yr}$ ) was lost to evapotranspiration (ET; table 8). About 5 percent $(24 \mathrm{~mm} /$ yr) of the precipitation falling in the SGPWM was discharged as surface-water runoff (table 8 ). Maximum runoff was simulated for the cells representing the main channels of the San Timoteo and San Gorgonio Rivers (fig. 23). The average 100 -year simulated recharge rate was $80 \mathrm{~mm} / \mathrm{yr}, 16$ percent of the average precipitation rate (table 8 ). Comparatively high recharge rates (greater than about $200 \mathrm{~mm} / \mathrm{yr}$ ) were simulated for larger stream channels underlain by alluvium, for the intra-channel areas of high-altitude alluvial valleys, as well as for locations at the base of side slopes where upslope areas with low permeability bedrock and thin soils transition to downslope areas with more permeable alluvium (fig. 24). The most recharge in the SGPGSA was along the channels of Noble Creek and San Gorgonio River (fig. 12).

Analysis of the temporal distribution of simulated water-budget components indicated great year-to-year variability compared to the long-term average, and runoff had the highest year-to-year variability (figs. 25, 26). Results for selected wet and dry water years indicated large differences in spatial distributions of annual recharge (fig. 28) and great variability in monthly recharge and runoff compared to the 100-year-average monthly values (fig. 29), with recharge varying by a factor of about 4 to 5 and runoff varying by a factor of about 15 to 17 for wet and dry years compared to the long-term average.

The SGPWM was used to evaluate differences in recharge between the area of the SGPGSA in the Banning and Cabazon HSAs and the surrounding San Bernardino and San Jacinto Peak mountain block areas upstream of the SGPGSA. Results (figs. 31, 32) showed that the SGPGSA had more recharge than the San Jacinto Peak mountain block because of the greater permeability of the alluvium and valley fill material in the SGPGSA, which allows for greater amounts of infiltration and percolation of runoff from the mountain block areas. In contrast to the San Jacinto Peak mountain block, the San Bernardino mountain block had more recharge than the SGPGSA because of major alluvium-filled valleys upstream of the SGPGSA that allow for large volumes of infiltration of runoff from the headwater areas of the San Bernardino Mountain block.

The upper San Gorgonio River subdrainage had the highest 100-year average recharge in the mountain block area outside of the SGPGSA because of the high-permeability of the alluvium underlying the main channel of the San Gorgonio River. Runoff from upstream subdrainages, including the summit areas such as Little San Gorgonio Peak in the San Bernardino mountain block, which have the most precipitation, readily infiltrates along the larger, alluviumfilled channel of the San Gorgonio River. The Smith Creek and the Potrero Creek tributaries of the San Gorgonio River also had relatively high recharge because of high-permeability alluvium underlying the main channels and the relatively highprecipitation in the headwater areas.

The effects of imperviousness on recharge and runoff were evaluated by mapping the difference between simulation results from simulations that included and that excluded imperviousness (figs. 33, 34). Runoff in the more developed areas increased by as much as 101 to $1,000 \mathrm{~mm} / \mathrm{yr}$ when imperviousness was included. The increased runoff for simulations that had imperviousness included was routed to the main channels of the San Gorgonio River, San Timoteo Creek, and Potrero Creek, increasing runoff by as much as 1,001 to $2,830 \mathrm{~mm} / \mathrm{yr}\left(7.1 \mathrm{E}-4 \mathrm{~m}^{3} / \mathrm{s}\right.$ to $\left.2.0 \mathrm{E}-3 \mathrm{~m}^{3} / \mathrm{s}\right)$ for some locations. Impervious areas resulted in increases in ET of as much as 51 to $305 \mathrm{~mm} / \mathrm{yr}$ for many locations downstream of the impervious areas in response to the infiltration of increased runoff from the impervious areas. For locations with significant (greater than 10 percent) imperviousness, recharge was found to decrease with increased imperviousness because the fraction of the cell area that can take on water and, thus, contribute to recharge decreases with increasing imperviousness. Similar to ET, recharge increased for locations downstream of the impervious areas in response to infiltration of the increased runoff from the impervious areas. The 100-year basin-wide average recharge for the impervious-excluded simulation was $78 \mathrm{~mm} / \mathrm{yr}$, compared to $80 \mathrm{~mm} / \mathrm{yr}$ for the impervious-included simulation.

The simulated long-term average recharge was compared to results from the previous model (Rewis and others, 2006). The average recharge simulated by the updated model for the smaller area of the previous model was $90 \mathrm{~mm} / \mathrm{yr}$ (about $8 \mathrm{~mm} / \mathrm{yr}$ more than the previous recharge estimate), with a maximum of $4,170 \mathrm{~mm} / \mathrm{yr}$, a minimum of $0.0 \mathrm{~mm} / \mathrm{yr}$, and a standard deviation of $190 \mathrm{~mm} / \mathrm{yr}$. The greatest increase in recharge of the updated model relative to the previous model was $4,160 \mathrm{~mm} / \mathrm{yr}$, and the greatest decrease relative to the previous model was $27,400 \mathrm{~mm} / \mathrm{yr}$, in the main channels, such as San Gorgonio River and Noble Creek (fig. 35). These large differences in recharge between the two models were mostly the result of differences in the locations of stream channels represented by the $30-\mathrm{m}$ grid of the previous model compared to the $150-\mathrm{m}$ grid of the updated model. 


\section{Estimating Natural Recharge in San Gorgonio Pass Watersheds, California, 1913-2012}

For both models, runoff was the most sensitive waterbudget component, with large year-to-year variability primarily caused by temporal variability in precipitation. Most years had runoff well below the long-term average, and periodic wetter than average years caused runoff to be many times greater than the long-term average. Runoff was also most sensitive to drought periods, and the average runoff rate during the California Department of Water Resource (DWR) drought periods was about 22 to 23 percent of the long-term average for water years 1930-2001. Recharge was also greatly reduced relative to the long-term mean during drought periods. For the updated model, recharge during the DWR drought years was 57 percent of the average rate for water years 1930-2001. For the previous model, recharge during the DWR drought years was 39 percent of the recharge rate for water years 1930-2001. In general, the long-term average rates from the updated model for water years 1930-2001 were similar to the 100-year average rates for water years 1913-2012. By using the updated model, average recharge for the DWR drought years was $43 \mathrm{~mm} / \mathrm{yr}$, or about 54 percent of the 100 -year average recharge rate of $80 \mathrm{~mm} / \mathrm{yr}$. Compared to recharge, runoff indicated more sensitivity to drought years. Average runoff for the DWR drought years was $5 \mathrm{~mm} / \mathrm{yr}$, or about 20 percent of the 100 -year average rate of $24 \mathrm{~mm} / \mathrm{yr}$. For most years of the 100 -year simulation period, both recharge and runoff were less than the long-term average rate.

Results from the SGPWM indicated that simulated runoff and recharge were most sensitive to the climate inputs, which, in turn, are interpolated, and therefore associated with some degree of uncertainty. Although a large number of climate stations were used to develop the daily climate inputs, the density of climate stations in the study area was low. The comparison with the state-wide drought periods indicated that the SGPWM climate did not always follow state-wide climate conditions and that more local-scale climate variability is likely to be important.

Results for both models indicated that infiltration of runoff was an important source of recharge for the SGPGSA, especially for the area of the SGPGSA and for mountain front recharge from the San Bernardino Mountains. The greatest localized recharge came from infiltrated runoff along the main stream channels. Both models also indicated that the yearto-year variability in runoff was very large, which, in-turn, resulted in large year-to-year variability in recharge. Intrachannel recharge in direct response to precipitation and snowmelt was less than recharge along channels; however, intrachannel recharge affected a much larger area. The updated model indicated slightly more recharge and runoff compared to the previous model, with the differences caused by a combination of different grid sizes used to develop the models, differences in the climate inputs and simulation periods, and the inclusion of seepage flow in the updated model.

The updated model provides estimates of natural recharge for a larger area than the previous model and includes all mountain front drainages upstream of the SGPGSA and having a potential to contribute runoff and recharge inflows to the
SGPGSA. For calculating long-term average water-budget components for the SGPGSA, the updated model provides a longer simulation period of 100 years, compared to the 72 -year period for the previous model. The updated model incorporated a seepage-flow component not simulated by the previous model, which allows for simulation of lateral redistribution of net infiltration below the root zone and can greatly change the spatial distribution of estimated recharge.

\section{References Cited}

Beven, K.J., Kirkby, M.J., 1979, A physically based, variable contributing area model of basin hydrology: Hydrological Sciences Bulletin, v. 24, p. 43-69.

Belcher, W.R., and Sweetkind, D.S., eds., 2010, Death Valley regional groundwater flow system, Nevada and CaliforniaHydrogeologic framework and transient groundwater flow model: U.S. Geological Survey Professional Paper 1711, $398 \mathrm{p}$.

Bloyd, R.M., 1971, Underground storage of imported water in the San Gorgonio Pass area, Southern California: U.S. Geological Survey Water-Supply Paper 1999-D, 37 p.

California Department of Forestry and Fire Protection, 2002, Monitoring land cover changes in California, California Land Cover Mapping and Monitoring Program, South Coast Project Area, July 2002, Fire and Resource Assessment Program, 161 p., accessed January 20, 2015, at http://frap.cdf. ca.gov/projects/land_cover/monitoring/pdfs/socdp_final2. pdf.

California Department of Water Resources, 2012, Drought in California: State of California, Natural Resources Agency, accessed November 2014 at http://www.water.ca.gov/waterconditions/docs/Drought2012.pdf.

California Department of Water Resources, 2003, California's groundwater: Bulletin 118, update 2003: Sacramento, Calif., State of California, The Resources Agency, Department of Water Resources, accessed July 1, 2004, at http://water. ca.gov/groundwater/bulletin118/report2003.cfm.

California Interagency Watershed Mapping Committee, 2004, The California Interagency Watershed Map of 1999 (updated May 2004): California Department of Fish and Game, available at http://www.atlas.ca.gov/download. $\mathrm{html} /$ /casil/inlandWaters.

California Irrigation Management Information System (CIMIS), 2005, Meteorological data: California Department of Water Resources and University of California at Davis, available at http://www.cimis.water.ca.gov/. 
Daly, C., Neilson, R.P., and Phillips, D.L., 1994, A statisticaltopographic model for mapping climatological precipitation over mountain terrain: Journal of Applied Meteorology, v. 33 , no. 2 , p. $140-158$.

Daly, C., Gibson, W.P., Doggett, M., Smith, J., and Taylor, G., 2004, Up-to-date monthly climate maps for the conterminous United States: Procedures of the 14th American Meteorological Society Conference on Applied Climatology, 84th American Meteorological Society Annual Meeting Combined Preprints, American Meteorological Society, Seattle, Washington, January 13-16, 2004, Paper P5.1, CD-ROM.

Doherty, John, 2008, PEST: Model-independent parameter estimation, user manual (5th ed.): Brisbane, Australia, Watermark Numerical Computing, 336 p.

EarthInfo, Inc., 2011, NCDC Summary of the Day, West: Boulder, Colo., Earth Info, Inc., CD ROM.

Farrar, C.D., Metzger, L.F., Nishikawa, Tracy, Koczot, K.M., and Reichard, E.G., 2006, Geohydrologic characterization, water-chemistry, and groundwater flow simulation model of the Sonoma Valley area, Sonoma County, California, with a section on basement rock configuration interpreted from gravity data by Victoria E. Langenheim: U.S. Geological Survey Scientific Investigations Report 2006-5092, 167 p.

Flint, A.L., and Childs, S.W., 1987, Calculation of solar radiation in mountainous terrain: Journal of Agricultural and Forest Meteorology, v. 40, p. 233-249.

Flint, A.L., and Childs, S.W., 1991, Use of the Priestley-Taylor evaporation equation for soil water limited conditions in a small forest clearcut: Agricultural and Forest Meteorology, v. 56, p. 247-260.

Flint, A.L., and Flint, L.E., 2007, Application of the basin characterization model to estimate in-place recharge and runoff potential in the Basin and Range carbonate-rock aquifer system, White Pine County, Nevada, and adjacent areas in Nevada and Utah: U.S. Geological Survey Scientific Investigations Report 2007-5099, 20 p.

Flint, L.E., and Martin, Peter, eds., 2012, with contributions by Brandt, Justin, Christensen, A.H., Flint, A.L., Flint, L.E., Hevesi, J.A., Jachens, Robert, Kulongoski, J.T., Martin, Peter, and Sneed, Michelle, 2012, Geohydrology of Big Bear Valley, California: Phase 1-geologic framework, recharge, and preliminary assessment of the source and age of groundwater: U.S. Geological Survey Scientific Investigations Report 2012-5100, 112 p., available at http://pubs. usgs.gov/sir/2012/5100/.

Gesch, D., Evans, G., Mauck, J., Hutchinson, J., Carswell, W.J., Jr., 2009, The National Map_Elevation: U.S. Geological Survey Fact Sheet 2009-3053, 4 p., accessed September 30, 2010, at http://pubs.usgs.gov/fs/2009/3053/.
Hevesi, J.A., Flint, A.L., and Flint, L.E., 2003, Simulation of net infiltration using a distributed parameter watershed model for the Death Valley regional flow system, Nevada and California: U.S. Geological Survey Water-Resources Investigation Report 03-4090, 104 p., available at http:// pubs.usgs.gov/wri/wri034090/.

Hevesi, J.A., Woolfenden, L.R., Niswonger, R.G., Regan, R.S., and Nishikawa, Tracy, 2011, Decoupled application of the integrated hydrologic model, GSFLOW, to estimate agricultural irrigation in the Santa Rosa Plain, California: Golden, Colorado, MODFLOW and More 2011 Conference Proceedings, p. 115-119.

Homer, C., Dewitz, J., Fry, J., Coan, M., Hossain, N., Larson, C., Herold, N., McKerrow, A., VanDriel, J.N., and Wickham, J., 2007, Completion of the 2001 National Land Cover Database for the Conterminous United States: Photogrammetric Engineering and Remote Sensing, v. 73, no. 4, p. 337-341, accessed March 2010, at http://www. asprs.org/a/publications/pers/2007journal/april/highlight. pdf.

Jennings, C.W., 1977, Geologic map of California: California Division of Mines and Geology, Geologic Data Map no. 2, scale 1:750,000.

Jeton, A.E., and Maurer, D.K., 2011, Precipitation and runoff simulations of select perennial and ephemeral watersheds in the middle Carson River basin, Eagle, Dayton, and Churchill Valleys, west-central Nevada: U.S. Geological Survey Scientific Investigations Report 2011-5066, 44 p.

Maidment, D.R., ed., 2002, Arc Hydro: GIS for Water Resources: Redlands, California, ESRI Press.

Markstrom, S.L., Niswonger, R.G., Regan, R.S., Prudic, D.E., and Barlow, P.M., 2008, GSFLOW-Coupled ground-water and surface-water flow model based on the integration of the Precipitation-Runoff Modeling System (PRMS) and the Modular Ground-Water Flow Model (MODFLOW-2005): U.S. Geological Survey Techniques and Methods 6-D1, $240 \mathrm{p}$.

Nash, J.E., and Sutcliffe, J.V., 1970, River flow forecasting through conceptual models part I-A discussion of principals: Journal of Hydrology, v. 10, no. 3, p. 282-290.

Nishikawa, Tracy, Izbicki, J.A., Hevesi, J.A., Stamos, C.L., and Martin, Peter, 2004, Evaluation of geohydrologic framework, recharge estimates, and groundwater flow of the Joshua Tree area, San Bernardino County, California: U.S. Geological Survey Scientific Investigations Report 2004-5267, 127 p. 
Reichard, E.G., Land, Michael, Crawford, S.M., Johnson, Tyler, Everett, R.R., Kulshan, T.V., Ponti, D.J., Halford, K.L., Johnson, T.A., Paybins, K.S., Nishikawa, Tracy, 2003, Geohydrology, geochemistry, and ground-water simulationoptimization of the Central and West Coast Basins, Los Angeles County, California: U.S. Geological Survey Water Resources Investigations Report: 2003-4065, 184 p.

Rewis, D.L., Christensen, A.H., Matti, J., Hevesi, J.A., Nishikawa, T., and Martin, P., 2006, Geology, groundwater hydrology, geochemistry, and groundwater simulation of the Beaumont and Banning storage units, San Gorgonio Pass Area, Riverside County, California: U. S. Geological Survey Scientific Investigations Report 2006-5026, 191 p.

Slack, J.R., Lorenz, D.L., and others, 2003, USGS library for S-PLUS for Windows-Release 2.1: U.S. Geological Survey Open-File Report 03-357.

U.S. Department of Agriculture, 1994, State soil geographic (STATSGO) Data base-Data use information: Natural Resource Conservation Service, Miscellaneous Publication no. 1492: Soil Survey Staff, Natural Resources Conservation Service, United States Department of Agriculture. U.S. General Soil Map (STATSGO) for California, accessed June 21, 2009, at http://sdmdataaccess.nrcs.usda.gov/.

U.S. Geological Survey, 2008, Documentation of computer program INFIL3.0-A distributed-parameter watershed model to estimate net infiltration below the root zone: U. S. Geological Survey Scientific Investigation Report 2008-5006, 98 p., available at http://pubs.usgs.gov/ $\operatorname{sir} / 2008 / 5006 /$.

Ward-Garrison, C., Markstrom, S.L., and Hay, L.E., 2009, Downsizer-A graphical user interface-based application for browsing, acquiring, and formatting time-series data for hydrologic modeling: U.S. Geological Survey Open-File Report 2009-1166, 27 p.

Woolfenden, L.R., and Nishikawa, Tracy, eds., 2014, Simulation of groundwater and surface-water resources of the Santa Rosa Plain watershed, Sonoma County, California: U.S. Geological Survey Scientific Investigations Report 2014-5052, 258 p., available at http://pubs.usgs.gov/ sir/2014/5052/. 
Prepared by the Sacramento Publishing Service Center.

For more information concerning this report, contact:

Director

U.S. Geological Survey

California Water Science Center

6000 J Street, Placer Hall

Sacramento, CA 95819

dc_ca@usgs.gov

or visit our Web site at:

http://ca.water.usgs.gov 
